\author{
UNIVERSIDADE DE SÃO PAULO \\ FACULDADE DE FILOSOFIA, LETRAS E CIÊNCIAS HUMANAS \\ DEPARTAMENTO DE SOCIOLOGIA \\ PROGRAMA DE PÓS-GRADUAÇÃO EM SOCIOLOGIA
}

THIAGO TRINDADE DE AGUIAR

Maquiando o trabalho: opacidade e transparência numa empresa de cosméticos global

VERSÃO CORRIGIDA

São Paulo 


\author{
UNIVERSIDADE DE SÃO PAULO \\ FACULDADE DE FILOSOFIA, LETRAS E CIÊNCIAS HUMANAS \\ DEPARTAMENTO DE SOCIOLOGIA \\ PROGRAMA DE PÓS-GRADUAÇÃO EM SOCIOLOGIA
}

\title{
Maquiando o trabalho: opacidade e transparência numa empresa de cosméticos global
}

\author{
VERSÃO CORRIGIDA
}

Thiago Trindade de Aguiar

\begin{abstract}
Dissertação apresentada ao Programa de PósGraduação em Sociologia do Departamento de Sociologia da Faculdade de Filosofia, Letras e Ciências Humanas da Universidade de São Paulo para a obtenção do título de Mestre em Sociologia.
\end{abstract}

Orientador: Prof. Dr. Leonardo Gomes Mello e Silva

São Paulo 
"Pois o aroma é um irmão da respiração. Com esta, ele penetra nas pessoas, elas não podem escapar-lhe caso queiram viver. E bem para dentro delas é que vai o aroma, diretamente para o coração, distinguindo lá categoricamente entre atração e menosprezo, nojo e prazer, amor e ódio. Quem dominasse os odores dominaria o coração das pessoas".

(Patrick Süskind - O perfume) 


\section{Agradecimentos}

A presente dissertação é fruto e coroamento de um longo período de estudos, trabalho e amadurecimento para o qual muitos contribuíram direta ou indiretamente. Certamente, os anos passados entre graduação e mestrado em nosso Prédio do Meio das Ciências Sociais, e a vida acadêmica e política experimentada na Universidade de São Paulo foram um grande divisor de águas em minha existência. Seria impossível mencionar todos os que de alguma forma foram parte do rico período que encerro com a finalização desta dissertação. No entanto, não há como não me lembrar de algumas pessoas fundamentais nessa trajetória.

Agradeço a meu pai e minha mãe, João e Cristina, por minha vida e pelo que sou, por seu apoio incondicional em todos os momentos, pelo carinho e pela amizade; a minha irmã Priscila, por nossa infância, cujas memórias alegres seguem permanentemente vivas em mim. Agradeço a meus avós porque com eles ou me lembrando deles não me esqueço de onde vim.

Não há como falar de todos meus amigos e camaradas, mas, através de Pedro, Gustavo, Giulia, Daniel, Renata e Vinagre (nossa turma das Ciências Sociais!), Evelin, Tiago e Mariana, posso agradecer a todas e todos vocês por terem me ensinado tanto! Pelos risos, pelas lutas, pela compreensão e pela paciência permanente (como nos últimos meses, quando a conclusão desta dissertação me dividiu completamente em momentos importantes que ora vivemos), só posso dizer: muito obrigado!

A meu orientador, Prof. Leonardo Mello e Silva, agradeço pelas muitas oportunidades que me proporcionou, pelas conversas francas e por sua orientação generosa e leve, sem deixar de ser cuidadosa, que me permitiu chegar até aqui.

Aos diretores do Sindicato dos Químicos Unificados e especialmente à assessora sindical Nádia Gebara, sou enormemente grato pela disponibilidade, pela atenção em vários momentos, pelo auxílio na busca de informações e pelas muitas conversas que pudemos manter ao longo dos últimos anos.

À Coordenação de Aperfeiçoamento de Pessoal de Nível Superior (CAPES), agradeço pela bolsa que viabilizou a realização desta pesquisa. Por acolhê-la, agradeço ao Departamento de Sociologia da USP. 
Por último, mas de modo algum menos importante, agradeço às muitas trabalhadoras e trabalhadores que me cederam alguns minutos de seu tempo para que pudéssemos conversar e, desse modo, possibilitaram a existência desta pesquisa. Suas trajetórias de luta cotidiana no trabalho e fora dele, percorrendo enormes distâncias por dia, enfrentando uma série de desafios e dificuldades em busca da realização de seus projetos e sonhos foram a inspiração deste trabalho. Se nele há algum êxito, deve-se sem dúvida a estas mulheres e homens com quem muito aprendi. 


\section{Resumo}

O presente trabalho tem por objetivo tratar do modo como a classe trabalhadora brasileira tem reagido às mudanças na organização da produção com a passagem de um padrão fordista para um pós-fordista a partir de um estudo de caso envolvendo trabalhadores da planta da Natura de Cajamar (SP). Com inspiração em Beaud e Pialoux (2009), aqui se pretende demonstrar como tais mudanças significaram a desestruturação do grupo operário e a ascensão de um novo grupo, marcado por novas características e sobre o qual os antigos valores, símbolos e referências não exercem mais a mesma influência. O interesse é analisar de que modo o novo grupo operário interage com as exigências da produção orientada por princípios do toyotismo, isto é, de qualidade e de flexibilidade. A descrição da fábrica, a apresentação de entrevistas, com trabalhadores e diretores da empresa, e de materiais corporativos e sindicais permitem analisar como foram introduzidas as mudanças na produção. Além disso, pretende-se debater o significado do descompasso entre a realidade concreta do trabalho na empresa e o discurso empresarial que prega a "transparência" das relações, de modo a identificar quais são os fundamentos do consentimento dos trabalhadores às práticas de produção flexíveis adotadas na fábrica.

Palavras-chave: Sociologia do Trabalho. Relações de trabalho. Processo de trabalho. Multinacional brasileira. Novos métodos de gestão. 


\begin{abstract}
This present work intends to discuss the way that Brazilian working class has reacted to changes in the organization of production after the transition from "fordism" to "post-fordism", using a case study around Natura's workers in the plant of Cajamar (São Paulo - Brasil). Inspired by Beaud and Pialoux (2009), the attemp is showing how these changes have meant a kind of dismantling for the group of workers and a rise of a new group of them, influenced by new characters. Old values, symbols and references do not exercise the same influence as they used to. The point is to examine the way that this new group interacts with the production's demands guided by toyotism elements, like quality and flexibility. The factory's description, the presentation of the interviews with workers and company's manangers, and the examining of company's and trade union's documents make possible to analyse how changes in production have been introduced in Natura. Beyond that, the meanings of the gap between the factual reality of working in the company and company's discourse, that talks about 'transparency' in relations, will also be examined to identify wich are the basis of workers' consent to the flexible production practices adopted in that factory.
\end{abstract}

Keywords: Sociology of Work. Working relations. Working process. Brazilian multinational corporation. New management methods. 


\section{Sumário}

Apresentação, questões e hipóteses

Capítulo 1 - Uma gigante brasileira dos cosméticos …............................................ 8

Bacias, rios e transparência: a fábrica da Natura em Cajamar ............................................................ 9

A abertura de capital e internacionalização da Natura: a criação de uma empresa cosmética global de

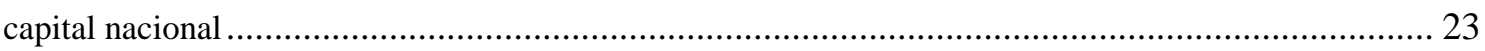

Opacidade e transparência: o lugar da "responsabilidade ambiental" como ativo econômico ………..... 29

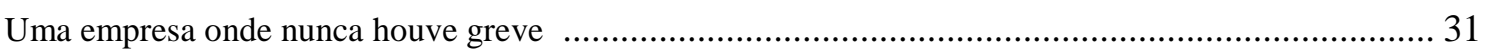

Capítulo 2 - Uma digressão sobre a organização dos trabalhadores brasileiros e o sindicalismo no pós-fordismo: há lugar para um novo "milagre"? ............................ 44

As mudanças na organização da produção e do trabalho: a passagem de um padrão fordista para um padrão pós-fordista.

As greves metalúrgicas de 1978, 1979 e 1980 como momento fundamental da formação da identidade

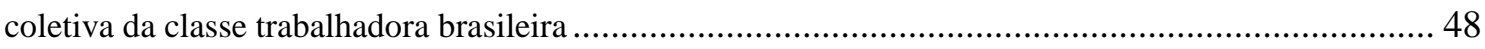

Algumas palavras sobre o sindicalismo corporativo brasileiro ............................................................ 52

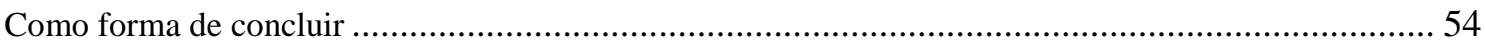

Capítulo 3 - Nos limites do "comprometimento": a demissão de trabalhadoras lesionadas e a desestruturação do antigo grupo operário na Natura ......................... 59

A articulação entre financeirização, aumento da produtividade e intensificação do trabalho no depoimento

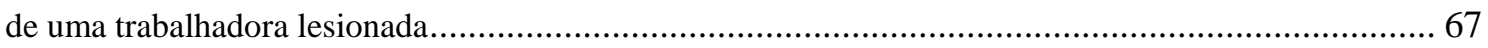

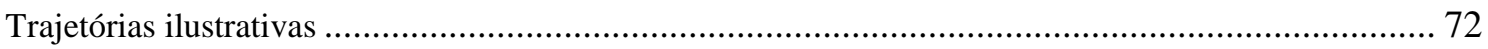

O "modelo da competência", o papel da formação e nova condição operária ......................................... 83

Qualificação, competência e divisão sexual do trabalho como parte da "nova condição operária": uma

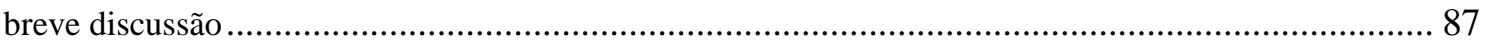

\section{Capítulo 4 - O sociólogo em uma "guerrilha simbólica": a "identificação de} propósitos" entre a empresa global e seu fundador bilionário …................................ 92

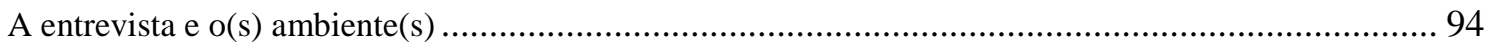

Filosofia e "refinamento": a "essência" da Natura e seu fundador ........................................................... 96

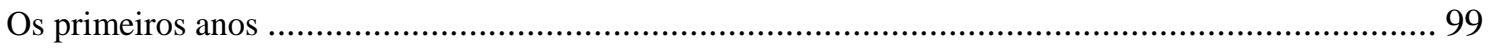

A fundação da Natura: a "identificação de propósito" como "ilusão biográfica" .................................. 102

A opacidade do trabalho na consolidação da gigante dos cosméticos ............................................... 108 
Capítulo 5 - Como breve forma de concluir: "opacidade" do trabalho e “transparência" empresarial como expressão da "dupla verdade do trabalho" .. 113

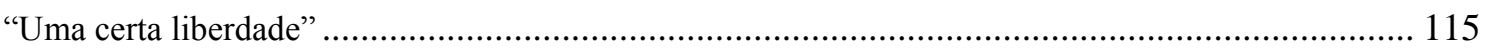

Transparência e opacidade para "assegurar e obscurecer a mais-valia” "............................................... 120

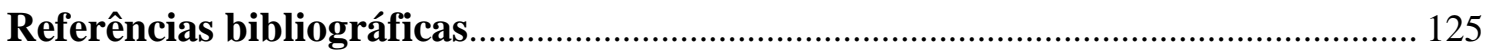




\section{Apresentação, questões e hipóteses}

As páginas seguintes reúnem as sínteses de um estudo de caso. Nele, pretendeuse abordar como a classe trabalhadora brasileira, do ponto de vista da sociabilidade do grupo de trabalhadores, tem reagido às mudanças na organização da produção com a passagem de um padrão fordista para um pós-fordista. Essa última caracterização é bem conhecida como sendo o modelo japonês ou toyotista de organização do trabalho às vezes conhecido como just in time (ANTUNES, 2006; BEYNON e NICHOLS, 2006; HIRATA, 1993).

Em especial, o interesse direciona-se ao grupo operário, que diretamente vivencia experiências concretas de implantação de novas tecnologias produtivas e de organização do trabalho. A empresa objeto da pesquisa, a Natura, é líder nacional do ramo de cosméticos e tem a particularidade de ser, além de um grande conglomerado de capital nacional que se internacionalizou, uma empresa pioneira e um caso bem sucedido de implantação de conceitos e práticas de produção flexíveis. A questão que move a investigação, portanto, é se se poderia encontrar, ali, uma mudança nas características da coletividade operária no sentido indicado por muitos que debateram o tema da transição para um padrão pós-fordista na literatura internacional de Sociologia do Trabalho.

As reflexões de Michel Pialoux e Stéphane Beaud, em Retorno à condição operária (2009), em particular, iluminaram aspectos importantes, para o que aqui se considera, do problema. Eles investigaram uma região industrial francesa (SochauxMontbéliard) com forte presença da fabricante de automóveis Peugeot. Seja pela dependência material à empresa ou pelo tipo de socialização das famílias operárias que se desenvolveu ao longo da história, a condição de "Operário-Peugeot" era parte constitutiva e fundamental de seus valores. Formou-se, ali, uma geração operária que desenvolveu práticas culturais, políticas (o sindicato, a relação com os partidos operários), simbólicas (o orgulho de fazer parte da "classe operária") e que se socializou tendo como pano de fundo um tipo de organização do trabalho, de relação com os colegas e com a chefia.

Os autores também mostram que as mudanças na produção pelas quais passou a empresa vieram acompanhadas de uma desvalorização simbólica e social, que 
ocasionou a desestruturação do grupo operário e o surgimento de uma "nova condição operária" assentada, entre outras coisas, 1) nas mudanças na composição etária dos trabalhadores da região e na socialização da nova geração operária; 2) no aumento do período e na forma de sua escolarização; 3) no tipo de empregos ofertados, nas novas exigências das empresas para preenchê-los e nas expectativas das novas gerações para ocupá-los; e, por fim, 4) no desenvolvimento de valores que se chocam com aqueles da geração operária anterior. Em suma, trata-se de um novo grupo social.

Pode-se considerar o trabalho de Beaud e Pialoux (2009) uma Sociologia da classe trabalhadora posterior aos "Trinta Gloriosos". Essa realidade afetou a França, mas afeta também o Brasil porque as tendências de organização do trabalho que se observam na Peugeot também são detectadas aqui, na empresa que é objeto da pesquisa.

Pretende-se, portanto, nas páginas e capítulos seguintes, investigar se é possível afirmar a existência de um processo, semelhante ao descrito por Beaud e Pialoux, de desestruturação operária e da emergência de um novo grupo social operário no Brasil, na medida permitida, evidentemente, pelas contribuições de um estudo de caso particular como este. Espera-se, então, acompanhar a formação de uma nova classe operária brasileira em que se podem notar, a princípio, algumas características: 1) maior escolaridade; 2) maior presença de jovens; 3) maior orientação para o consumo; 4) menor vinculação a sindicatos e associações; 5) orientação pela carreira; e 6) consolidação da inserção da mulher na força de trabalho. Trabalhos recentes no campo vêm apontando tendências análogas tanto no âmbito da organização como no do mercado de trabalho (BENDAZZOLI, 2003; COMIN, CARDOSO e CAMPOS, 1997; TOMIZAKI, 2007).

Para Jacques Freyssinet (2009), a flexibilização não é uma lei tendencial do capitalismo e responde a exigências contraditórias, cuja aplicação varia de acordo com o contexto nacional e com a correlação de forças entre as classes sociais. Ao discutir as tendências da introdução de flexibilidade na Europa ${ }^{2}$, portanto, sublinha este elemento de desigualdade entre os casos nacionais, apesar de ser possível apontar uma direção geral nas medidas de flexibilidade introduzidas nesses países. Por um lado, assistiu-se à

\footnotetext{
${ }^{1}$ Termo consagrado na literatura sociológica que caracteriza o período de cerca de trinta anos que se estendeu de 1945, com o final da II Guerra Mundial, a 1973, quando houve o primeiro choque do petróleo. Os "Trinta Gloriosos" foram um período de intensa recuperação, a princípio, e de longa expansão econômica nos países centrais. Para David Harvey, tal período "teve como base um conjunto de práticas de controle do trabalho, tecnologias, hábitos de consumo e configurações de poder políticoeconômico", que pode, "com razão, ser chamado de fordista-keynesiano" (HARVEY, 2011: 119).

${ }^{2}$ Freyssinet analisa especialmente o caso francês e, numa abordagem comparativa, os 15 primeiros países a compor a União Europeia (UE15).
} 
emergência de novas formas de emprego (com destaque para as modalidades de trabalho em tempo parcial, os contratos temporários e as políticas de emprego através de contratos subsidiados). Além disso, também emergiram formas de flexibilidade do tempo de trabalho e, por fim, dos modos de determinação da renda do trabalho (participação nos lucros, formas de remuneração que levam em conta a rentabilidade da empresa e que não levam em conta o caráter jurídico do salário, etc.). De qualquer modo, para Freyssinet, estaria em jogo, no caso europeu, uma verdadeira mudança no modo de regulação social - das normas e do modo de produção das normas.

Fica claro, pelo exposto, que seria um equívoco falar a respeito da simples transposição de "modelos", já que, como afirma Burawoy ${ }^{3}$ (1990), há um processo de desenvolvimento desigual e combinado do capitalismo mundial. A inspiração, neste trabalho, vinda de Beaud e Pialoux (2009), portanto, indica menos eventuais semelhanças entre os casos nacionais francês e brasileiro e mais a riqueza, de um ponto de vista sociológico, de suas reflexões a respeito do grupo operário que vivenciou a transição de padrões fordistas da produção e do trabalho para padrões pós-fordistas.

Sem perder isto de vista, é possível, no entanto, enxergar semelhanças em algumas tendências. Dedecca (2009), apoiando-se na terminologia de Burawoy, afirma que a introdução de medidas de flexibilização - como a Participação nos Lucros e Resultados (PLR), a introdução dos bancos de horas, a emergência de modalidades de contratação de serviços de pessoa jurídica (“pejotismo”) - no Brasil se deu nos marcos de um mercado de trabalho já flexível, com a presença de uma forte informalidade e fraca rede de proteção social. Dessa forma, é como se, aqui, tal como nos países centrais, já se pudesse falar na emergência, nos termos de Burawoy (1990), de um "regime despótico-hegêmonico", mas que se originou, no entanto, diferentemente dos países centrais, através de um salto direto do "regime despótico", sem passar por um período "hegemônico".

Neste trabalho, estruturado em cinco capítulos, pretende-se discutir essas questões a partir da pesquisa de campo realizada, com abordagem qualitativa, e da análise do material obtido por meio dela, como entrevistas realizadas com trabalhadores da Natura, sindicalistas, gerentes, diretores e o fundador da companhia Luiz Seabra. Pôde-se ter acesso a uma série de materiais disponibilizados pelo Sindicato dos Químicos Unificados (regional Osasco) e pela Natura, em particular seus relatórios

\footnotetext{
${ }^{3}$ Evidentemente inspirado em Leon Trotski.
} 
anuais, que trazem várias informações sobre sua gestão, desempenho econômico, localização de mercado, entre outras.

O primeiro contato com o grupo de trabalhadores da Natura deu-se por meio do caso de demissão de 33 trabalhadoras lesionadas, sobre o qual se debruçará o capítulo 3. Foi possível conhecer boa parte delas através do Sindicato dos Químicos. Posteriormente, por meio de algumas indicações fornecidas pelas trabalhadoras demitidas, foram realizadas algumas entrevistas com trabalhadores da planta de Cajamar. No entanto, a entrada na fábrica e, a partir dela, a realização de entrevistas com mais trabalhadores de Cajamar e com gerentes e diretores da empresa, demorou por volta de 1 ano por conta das dificuldades impostas pela Natura, que sistematicamente recusava os pedidos de entrevista e de informações solicitados. Tal situação, como se explicará no capítulo 4, modificou-se a partir da entrevista com Luiz Seabra, cuja realização foi obra do mais puro acaso, que vez por outra socorre o trabalho do pesquisador.

Apesar de ter sido possível, a partir de então, realizar algumas visitas à fábrica, conversar com trabalhadores da planta, além de gerentes e diretores da empresa, o acesso a informações continuou bastante restrito e dificultou o aprofundamento da discussão de algumas das questões que se pretendia realizar nesta dissertação. Como se mostrará ao final do capítulo 1, uma série de dados, com os quais seria possível melhor caracterizar o grupo de trabalhadores da empresa, não foi obtida, apesar de insistentes tentativas com a área de Recursos Humanos da empresa, por conta da alegada política empresarial de não oferecer dados que não constem de seus relatórios anuais.

O capítulo 1 está direcionado a apresentar aspectos da empresa, a organização de sua produção, um pouco de sua história e o avanço em sua internacionalização ocorrido em anos recentes. Além disso, de modo a situar o leitor, será feita uma descrição mais detida da planta de Cajamar e da introdução de formas flexíveis de organização da produção, como o TPM e as células semiautônomas, através das falas de alguns trabalhadores que viveram o período de transição após a inauguração da nova planta da Natura em 2001. Por último, no capítulo, será abordada a relação entre empresa e sindicato, bem como o modo como os trabalhadores reconhecem sua entidade sindical e avaliam as formas de mobilização e de negociação anual do dissídio.

Uma discussão retrospectiva sobre o padrão de relações industriais brasileiro e sobre os desafios do sindicalismo no país será feita no capítulo 2 a fim de enquadrar as mudanças recentes na produção e avaliar que consequências estas podem ter para as 
possibilidades de ação coletiva dos trabalhadores. Desse modo, à luz de discussões já clássicas na Sociologia do Trabalho, pretende-se colocar em questão alguns diagnósticos a respeito do sindicalismo no Brasil.

No capítulo 3, o esforço é de debruçar-se sobre os elementos do que aqui se tem apresentado como desestruturação do grupo operário. Para tanto, boa parte da atenção estará direcionada ao caso de demissão de 33 trabalhadoras portadoras de Lesão por Esforços Repetitivos (LER) na Natura em 2010. No capítulo, serão investigadas as relações entre a flexibilidade da produção e do trabalho, o aumento da produtividade, o regime de metas e a PLR, a intensificação do trabalho e o risco de lesões no grupo de trabalhadores. Também se abordarão a financeirização da empresa como um dos fundamentos das transformações vividas, além do estímulo ao aumento da escolarização do grupo operário por parte da empresa, sob a égide do "modelo da competência" e das avaliações internas. Os efeitos destas questões no que se refere ao aumento da competitividade entre os pares na produção e a consequente erosão de padrões de solidariedade coletiva serão postos em questão pelas vozes não apenas das trabalhadoras lesionadas demitidas como também de diversos outros trabalhadores cujas trajetórias ilustram as mudanças, expectativas e mentalidades presentes no grupo operário.

O capítulo 4 trata de algumas reflexões sobre o discurso empresarial articulado pela Natura a partir da entrevista realizada com Luiz Seabra, em que transparecem o esforço empreendido pela empresa em busca da "identificação de propósitos" entre companhia e os trabalhadores, e uma tensão, ou contradição, visível entre o discurso da "transparência", valorizado pela Natura, e uma certa "opacidade do trabalho" na empresa. A entrevista e a situação na qual esta se desenvolveu serão apresentadas para melhor abordar as consequências para o trabalho do discurso empresarial. Além disso, propõe-se ali a discussão sobre uma espécie de "guerrilha simbólica" realizada entre sociólogo e empresário durante a entrevista. O objetivo, dessa forma, será tratar da trajetória de Seabra e da empresa a partir do auxílio de noções como a de "ilusão biográfica" (BOURDIEU, 1998) além de possíveis nexos com as reflexões posteriores sobre a noção de "dupla verdade do trabalho" (BOURDIEU, 2007) que são realizadas no capítulo dedicado à conclusão da dissertação.

Portanto, finalmente, o capítulo 5 reúne breves considerações, como forma de conclusão, nas quais se pretende debater os fundamentos da aparente aceitação, por parte do grupo de trabalhadores da Natura, da organização flexível do trabalho e de suas consequências. Desse modo, está em questão uma discussão sobre o consentimento 
operário, para a qual serão mobilizados argumentos de autores como Bourdieu, Burawoy, Braverman e Harvey de modo a auxiliar as reflexões sobre a ambiguidade entre a "transparência" pregada pelo discurso empresarial e a "opacidade" que parece permear o trabalho numa empresa bem sucedida na implantação da flexibilidade e da obtenção do aumento da produtividade, dos lucros e da manutenção de fluxos tensos de produção, mobilizados por uma enorme demanda alimentada pelo exército de mais de 1,5 milhão de consultoras (revendedoras) da Natura. O que está por trás de tamanho sucesso empresarial?

A busca, dessa forma, nas páginas seguintes, é a de avaliar uma série de hipóteses que norteiam este trabalho. A saber:

1) A partir dos argumentos de Beaud e Pialoux (2009) sobre o grupo operário da Peugeot-Sochaux e dos trabalhos de autores brasileiros sobre as novas tendências de organização do trabalho em diversos setores (BENDAZZOLI, 2003; COMIN, CARDOSO e CAMPOS, 1997, ANTUNES, 2006), pode-se apontar para uma mudança demográfica (etária, de gênero, qualificação, escolaridade e origem) de um grupo social e para a criação de um novo. Trata-se, no entanto, mais de uma criação da empresa do que da condensação histórica de hábitos, valores, crenças e projetos políticos de um determinado grupo social. Desse modo, a primeira hipótese é a de que também estamos diante, na empresa objeto de estudo, de um processo de desestruturação do antigo grupo operário e da ascensão de um novo grupo, conforme discutido acima ${ }^{4}$;

2) Tal situação não é casual. Ela responde a um movimento mais geral de criação de uma sociabilidade de empresa, que passa a ser o vetor do coletivo operário, em oposição ao que se passou no período dos "Trinta Gloriosos", quando o vetor do coletivo operário estava fora da empresa, na relação salarial fordista (CASTEL, 2005; BEYNON, 1995). Entende-se, aqui, como vetor de criação do coletivo, o seguinte: cidade, laços de vizinhança, a frequentação recíproca das famílias, participação em eventos esportivos, políticos e culturais ou religiosos. A segunda hipótese, nesse sentido, é a de que a constituição do novo grupo operário está mais submetida às exigências, disposições e expectativas da empresa "moderna", que adotou novos princípios de organização do trabalho. Pretende-se deter, em particular, nas formas de gestão do trabalho e de como elas influenciam a identidade do grupo. Por exemplo, em

\footnotetext{
4 Apesar de este trabalho não tratar diretamente da questão da divisão sexual do trabalho, ela parece ter relevo no que se está tratando como a criação de um novo grupo operário. Por isso, no capítulo 3 serão abordados alguns aspectos a respeito das questões de gênero e trabalho, levando-se em conta a presença maciça de força de trabalho feminina na Natura.
} 
que medida o trabalho dito "em grupo" contribui para a fragmentação da identidade coletiva dos que dele participam. Com isso, a tentativa é de avaliar a influência de estratégias tais como o just in time, as células de produção e a avaliação por competência. O pressuposto é de que essas mudanças no modo de efetuar o trabalho têm um profundo impacto na sociabilidade da classe. Juntamente com as mudanças no modo de trabalhar, pretende-se analisar o impacto das mudanças na remuneração do trabalho (como, especialmente, a PLR) (BURAWOY, 1989; MELLO E SILVA, 2010);

3) A partir do contexto dessas mudanças, como terceira hipótese, pode-se indicar que tal tendência não se encontra somente na Natura, mas também em outras empresas que sofreram o mesmo processo de mudança de um padrão fordista para um padrão pósfordista. A implicação dessa hipótese é que o estudo de caso tem uma relevância para além de seu caso concreto, ou seja, responde a uma tendência mais geral da economia global e da brasileira em particular; e

4) Esse movimento da firma global tem sido estudado tradicionalmente como sendo protagonizado por multinacionais. No entanto, o que se tem observado, agora, a partir da história recente, é a criação de grandes conglomerados de capital nacional que se internacionalizam e funcionam como multinacionais brasileiras, como é o caso da Natura. Este é um tópico marginal para cuja compreensão a pesquisa pode ajudar a contribuir a partir de uma perspectiva sociológica focada na coletividade dos trabalhadores. Em suma, pode-se dizer que tal processo terá uma correspondência social com a formação de uma nova classe operária brasileira? Trata-se de uma instigante reflexão que aqui se apresenta como a quarta hipótese de trabalho, cuja resposta, evidentemente, extrapolaria os objetivos deste estudo de caso e da presente dissertação. 


\section{Capítulo 1 - Uma gigante brasileira dos cosméticos}

Fundada em 1969, a Natura é uma multinacional brasileira sediada em Cajamar (SP), onde também se localiza sua unidade de produção no Brasil. Líder brasileira nos setores de higiene pessoal, perfumaria e $\operatorname{cosméticos}^{5}$ e com grande presença internacional, a empresa possui operações próprias na Argentina, no Chile, na Colômbia, no México e no Peru. Na França, possui uma flag-ship store (loja-conceito), "uma unidade voltada à aquisição de experiência e proximidade estratégica com o principal mercado de cosméticos mundial"6, além de uma rede de cerca de 3000 consultoras que atuam naquele país ${ }^{7}$. Seus produtos também são comercializados na Bolívia, na Guatemala, em Honduras e em El Salvador. Além disso, na Austrália, no final de 2012, como parte de uma nova estratégia de internacionalização que se abordará nas páginas seguintes, a Natura comprou o controle acionário da Emeis Holdings, que opera naquele país a marca de cosméticos AESOP.

Controlada majoritariamente por acionistas brasileiros, em 2012, a empresa contava com 6700 trabalhadores empregados ${ }^{8}$. "Em média, (...) nós temos em torno de 3000 [trabalhadores] na área operacional, 1000 e poucos em vendas e os outros $1000 \mathrm{e}$ poucos no administrativo. Isso no Brasil”, afirma Susana Diniz, então diretora de Recursos Humanos da empresa ${ }^{9}$. Fora do Brasil, na América Latina e na França, ainda de acordo com ela, a maior proporção é de trabalhadores em vendas, seguidos pelo setor administrativo e pela operação.

Além deste número de trabalhadores diretamente contratados, a Natura conta com uma rede de quase 1,5 milhão de consultoras e consultores no Brasil e no mundo ${ }^{10}$,

\footnotetext{
5 A intensa competição no mercado brasileiro de produtos cosméticos e de higiene pessoal, o terceiro maior do mundo, com receitas anuais de R\$ 34 bi, foi abordada em reportagem da Folha de São Paulo de 18 de maio de 2013 ("Sob ataque de rivais, Natura faz mudanças"). Em 2012, a Natura perdeu 1 ponto percentual de participação em relação ao ano anterior, mantendo a liderança do setor com $13,4 \%$ do mercado nacional. Acompanham-na, na sequência, a gigante multinacional Unilever, com 11,9\%, a multinacional P\&G e O Boticário, empatados com $9,1 \%$ do mercado cada. A AVON, concorrente histórica da Natura no setor de cosméticos no país, ainda de acordo com os dados levantados pela Folha, possuía naquele ano $7,2 \%$ do mercado.

6 De acordo com informações do Relatório Natura 2012. Disponível em http:// elatorio.natura.com.br/relatorio/node/18

${ }^{7}$ Informação fornecida em entrevista por Luiz Seabra, fundador e copresidente da Natura.

8 De acordo com dados do Relatório Natura 2012. Disponível em http:// http://relatorio.natura.com.br/relatorio/node/7.

${ }^{9}$ Susana não é mais diretora de Recursos Humanos da Natura. No fim de 2013, ocorreu uma troca nesta diretoria e ela deixou a empresa. Os nomes de todos os entrevistados, à exceção de Luiz Seabra, fundador da Natura, entre trabalhadores, gerentes e diretores da empresa, foram sempre substituídos por nomes fictícios ao longo desta dissertação.

${ }^{10}$ Segundo dados do Relatório Natura 2012 mencionado na nota 5.
} 
principais responsáveis pela distribuição dos produtos da empresa. A Natura notabilizou-se pela adoção do sistema de venda direta, que havia sido introduzido no Brasil pela AVON 10 anos antes de sua fundação. As distribuidoras, que vendem os produtos e não possuem qualquer vínculo empregatício, recebem na Natura o nome de "consultoras". Sobre o trabalho delas e seu papel fundamental na história e no desempenho da empresa, ver Abílio (2011) (2012).

Luiz Seabra, fundador da Natura, em entrevista ${ }^{11}$, afirmou que se chegou a cogitar, nos primeiros anos da empresa, um modelo de distribuição através de lojas, tal como escolheu a rede concorrente O Boticário quando foi fundada alguns anos depois. No entanto, optou-se pela distribuição através das consultoras logo nos primeiros anos de atividade da Natura, seguindo o exemplo da AVON:

"Eu acho que foi em 59 ou 58 que a AVON foi inaugurada no Brasil e nós em 73 começamos a fazer algumas experiências com distribuidores, que foram experiências decisivas, que mostraram que tinham um potencial muito grande para nós realmente encontrarmos uma estrada, que nos entregasse escala, que tivéssemos escala, porque até então era muito limitada a nossa produção".

A Natura alcançou em 2012 receita líquida de R\$ 6,346 bilhões e um lucro líquido de R \$ 861 milhões $^{12}$. Empresa de capital aberto, foi fundada por Antônio Luiz da Cunha Seabra, hoje um de seus três copresidentes, junto a Guilherme Leal e Pedro Luiz Barreira Passos. Os copresidentes da Natura figuram em posições destacadas nas listas de maiores fortunas do país e do mundo. Luiz Seabra ocupa a $14^{\mathrm{a}}$ posição brasileira e $423^{\mathrm{a}}$ no mundo entre as maiores fortunas, de acordo com ranking da revista Forbes $^{13}$ (março de 2013), com 3,2 bilhões de dólares. Guilherme Leal (posição $831^{\text {a }}$ do mundo e $29^{\mathrm{a}}$ do Brasil de acordo com a mesma edição da Forbes ${ }^{14}$ ), também bilionário, ganhou notoriedade nacional ao candidatar-se, em 2010, ao cargo de Vice-Presidente da República na chapa de Marina Silva (então no PV), adotando o discurso da "sustentabilidade".

\section{Bacias, rios e transparência: a fábrica da Natura em Cajamar}

Originalmente instalada no bairro de Santo Amaro, em São Paulo, a Natura transferiu suas atividades produtivas para Itapecerica da Serra, onde funcionou por

\footnotetext{
${ }^{11}$ No capítulo 4, onde se apresentará esta entrevista com Seabra, o papel das consultoras e sua adoção pela Natura para distribuir os produtos serão novamente abordados.

${ }^{12}$ Ainda de acordo com dados do Relatório Natura 2012.

${ }^{13}$ Disponível em http://www.forbes.com/profile/antonio-luiz-seabra/.

${ }^{14}$ Disponível em http://www.forbes.com/profile/guilherme-peirao-leal/.
} 
muitos anos. Finalmente, em 2001, as atividades de produção foram transferidas para Cajamar, onde a empresa também instalou um centro de pesquisa e desenvolvimento. $\mathrm{Na}$ nova fábrica, foram introduzidas novas máquinas e uma nova organização da produção e do trabalho de acordo com princípios flexíveis. A fábrica funciona seis dias por semana, em três turnos, 24 horas por dia.

Localizada no quilômetro 30,5 da rodovia Anhanguera, em Cajamar, a fábrica da Natura foi inaugurada em 2001. Atualmente, é a maior unidade produtiva da empresa. No Brasil, há outra unidade em Benevides, Pará, onde se fabricam sabonetes, e, na Argentina, onde além de sabonetes são envasados perfumes. No segundo semestre de 2013, foi inaugurado um novo centro de distribuição (chamado na Natura de picking ${ }^{15}$ ) apenas alguns quilômetros distante da fábrica de Cajamar, onde até então estas atividades também estavam abrigadas. O novo picking localiza-se no quilômetro 13 da rodovia Anhanguera, no município de São Paulo. Nele, são armazenados os produtos que, posteriormente, de acordo com as encomendas feitas pelas consultoras, são enviados a suas residências para que sejam vendidos. Com o espaço liberado pela mudança do picking, a Natura começou a construir uma nova área de produção.

A planta de Cajamar é estruturada em três fábricas, unidades que recebem nomes de bacias de rios brasileiros e produzem artigos distintos. A primeira delas, "Rio da Prata", fabrica maquiagens e bisnagas. Na fábrica "Rio São Francisco", são produzidos perfumes, óleos e desodorantes. A última delas, "Rio Amazonas", produz cremes e loções. Há, além das fábricas, o Armazém Vertical (chamado na fábrica de AV), onde são estocados insumos e matérias-primas, organizados e distribuídos para a produção automaticamente através de um sistema que utiliza código de barras para a catalogação e localização de cada material, além de um sistema de transporte com empilhadeiras automáticas e trilhos que percorrem o AV. A produção de shampoos e de parte dos sabonetes da Natura é terceirizada. Na Natura, as células semiautônomas (por vezes também chamadas de linhas pelos operários) de cada fábrica recebem o nome de um rio

\footnotetext{
15 Para Antônio, trabalhador da Natura e diretor do Sindicato dos Químicos, a mudança do picking também foi planejada levando em conta a possibilidade da mudança de município e de representação sindical dos trabalhadores deste setor. Segundo diretores do sindicato, houve mudança de razão social: criou-se a "Natura Picking", sediada no município de São Paulo. Desse modo, outro sindicato passou a representar os trabalhadores do picking, tidos por eles como mais combativos. Por isso, ainda segundo diretores do sindicato, no período de transição para a nova área de logística no quilômetro 13 da Anhanguera, já havia uma tentativa da gerência de dificultar a participação destes trabalhadores das assembleias na porta da fábrica em Cajamar.
} 
da "bacia" onde se localiza. Na fábrica "Rio da Prata", por exemplo, estão as células (ou linhas) de nome "Rio Paraná" e "Rio Tietê".

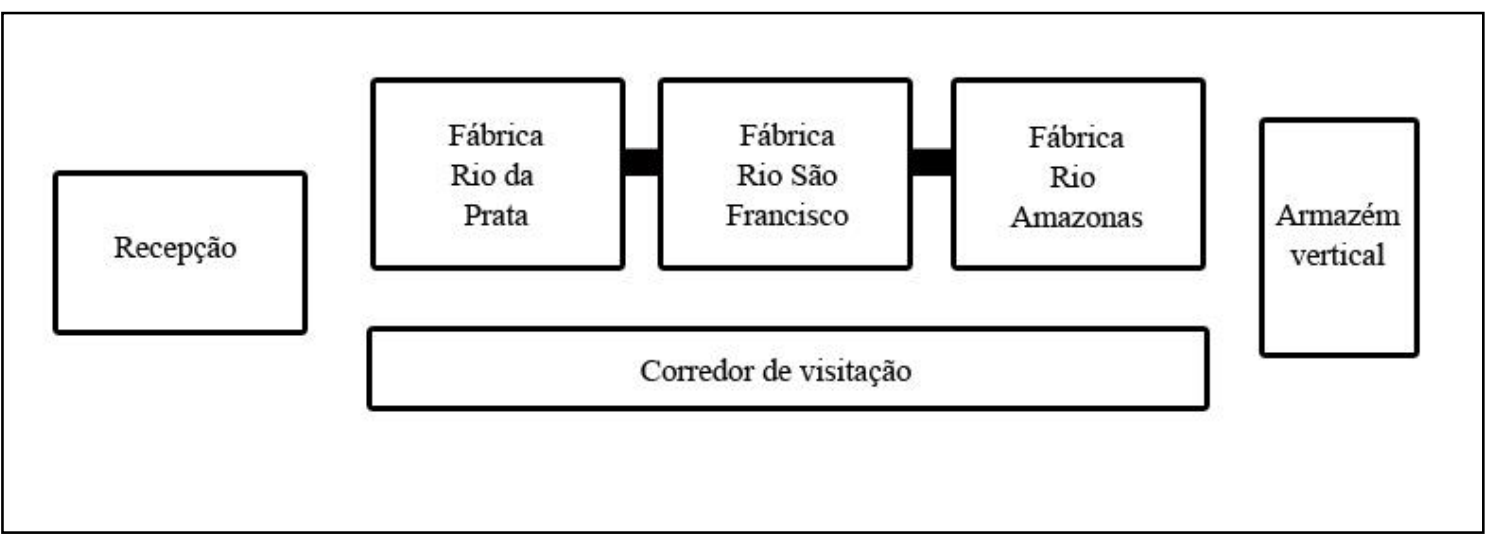

Figura 1: Ilustração esquemática da disposição das fábricas e do AV na planta da Natura em Cajamar ${ }^{16}$.

A recepção da fábrica é ampla e feita de concreto. No entanto, um grande painel com letras brancas - que afirma ser o "bem estar bem" a razão de ser da empresa - e um hall com sofás, plantas tropicais e um totem eletrônico, com informações sobre a história da companhia, trazem a impressão de amplitude do espaço e limpeza, confirmada pela permanente essência de erva doce vaporizada no ambiente. Desta recepção ao fim do edifício principal, um longo corredor permite percorrer as principais áreas da planta. Em particular, o corredor, por onde circulam cerca de 2000 visitantes $^{17}$ por mês, é a única forma de ver as fábricas. Nos “rios", somente operários ou pessoas individualmente autorizadas pela diretoria da empresa, na maioria grandes investidores interessados em conhecer de perto a produção, podem entrar.

Do corredor, chamam a atenção os amplos vidros que funcionam como parede de cada uma das fábricas. Por meio deles, é possível ver operários, a maioria dos quais vestidos de branco (alguns vestem macacão e toucas coloridas por questões de segurança ou por ocuparem funções específicas que requerem identificação), monitorando o fluxo da produção das máquinas ou encaixotando os produtos. Walter,

\footnotetext{
${ }^{16}$ Esta representação, produzida a partir de visita monitorada à planta, é meramente ilustrativa e, portanto, inexata se se levam em conta as reais proporções e localizações relativas dos espaços. O objetivo é meramente localizar o leitor a respeito das partes da planta descritas no texto. Agradeço à amiga Adria Meira pelo auxílio na montagem desta ilustração.

${ }^{17}$ Entre os visitantes estão consultoras da Natura convidadas a conhecer a empresa, investidores e estudantes das mais diversas áreas.
} 
formado em Relações Internacionais ${ }^{18}$ e um dos responsáveis pelas visitas guiadas à empresa, esclarece: os vidros são uma das demonstrações da "transparência" que norteia as atividades da empresa. "Transparência com os investidores, consumidores e consultoras", afirma. Esta é uma palavra que correntemente reaparece no discurso empresarial. Chama a atenção, no entanto, que a transparência dos vidros permita apenas ver, muito à distância, como se dá a produção, a gestão e as relações de trabalho na empresa.

Em termos de organização do trabalho, a planta da Natura de Cajamar adota uma série de procedimentos consoantes com as tendências de modernização da produção que se desenvolveram nos países centrais e, ao longo das últimas décadas, foram implementados no Brasil. Podem-se destacar as células e o regime de metas de produção. Além disso, conta com um programa de participação nos lucros e resultados $(\mathrm{PLR})^{19}$.

Susana Diniz ${ }^{20}$, diretora de Recursos Humanos da Natura, acompanhou de perto os primeiros anos de funcionamento da nova fábrica e as novas políticas de gestão da produção e do trabalho ali adotadas. Sua trajetória iniciou-se em bancos e no mercado financeiro. Em 2003, antes de assumir a diretoria de RH, Diniz chegou à empresa contratada para implantar processos de educação corporativa. Segundo ela a decisão de construir a nova fábrica foi um momento de inflexão, motivado por um período anterior de crescimento robusto da Natura, que continuou após Cajamar, e pela adoção, em anos anteriores, antes mesmo da abertura de capital, de um novo modelo de gestão.

"Nos últimos 20 anos, ela [a Natura] começou a crescer e ela estava com uma fábrica em Itapecerica, que tinha todo seu olhar para a qualidade, produtividade, mas que foi ficando pequena muito rápido. Tem um processo de crescimento de $30,40 \%$ ao ano nesse período. É completamente absurdo no mercado isto. Pouquíssima ou nenhuma empresa fez esse movimento. Acontece que a empresa teve que se profissionalizar - eu vou usar esse termo - muito rapidamente (...). E foi nesse momento que começou a mudar toda a estratégia de governança inclusive da organização (...). Então, se estabeleceu um processo em que íamos trazer mais um comitê executivo, criou-se a necessidade de já trazer a auditoria interna, sem que a gente fosse uma empresa aberta, fazia dividendos de ações, mesmo que a gente não tivesse ações na bolsa, era só fictício. Então, eles começaram a profissionalizar a empresa e ficar uma empresa de tamanho grande - na verdade, não no tamanho, mas de atitude, de atividade de tamanho de empresa grande e multinacional, com as melhores práticas dentro de uma empresa que era nacional e ainda de médio porte (...).

\footnotetext{
${ }^{18}$ Requisito da empresa pelo fato de lidar com investidores e público estrangeiros.

${ }^{19}$ Para um balanço mais detido das consequências da implementação da PLR no Brasil e que estão em linha com as mudanças na organização do trabalho, ver Krein (2007) e Galvão (2003).

${ }^{20}$ Conforme já dito acima, em todas as menções a trabalhadores, pessoal da gerência e direção da empresa ou sindicalistas, serão adotados nomes fictícios.
} 
Num determinado momento se decidiu então construir [a nova fábrica em Cajamar] e foi um salto bastante importante, foi um movimento que eu posso te dizer de muita audácia até. Quando eles mudaram, as fábricas ficavam quase que mais da metade [de seu espaço] vazias. Eles brincavam que iam alugar algumas partes para fazer salão de baile. Nenhuma das fábricas trabalhava 24 horas, nenhuma das fábricas trabalhava no fim de semana. Então, era outro nível de produção. E isto foi um processo tão rápido que, desde que eu entrei aqui [em 2003], ela não trabalhava 24 [horas] por 7 [dias] e hoje elas trabalham 24 por 7 , nós temos duas fábricas terceirizadas, uma fábrica em Belém [refere-se à fábrica de sabonetes em Benevides-PA], que nós levamos daqui, a gente continua produzindo parte aqui, na Argentina, na América Latina já tem produção porque na verdade a gente nem consegue atender a tudo isto (...). Houve uma época em que tudo saía daqui [de Cajamar], mesmo para França, Argentina, Chile, Peru, Venezuela (...).

Você começa a produzir num volume e numa quantidade que, de fato, você não suporta no processo quase que manual que ficava antes, não consegue. A gente agora olha para as máquinas daqui e fala: nossa, que coisa mais retrógada! Era o mais moderno que tinha 5 anos atrás e hoje você tem lá no picking [área de logística e distribuição] coisas que um autista pode desenvolver, trabalhar e separar produtos com super naturalidade. É um salto brutal de como você pode ganhar eficiência e produtividade (...)".

Mas as mudanças com a nova fábrica não se deram apenas, obviamente, no volume da produção, nos lucros ou nas novas estratégias de gestão e de negócios. O grupo operário da Natura vivenciou não apenas a mudança física da planta, como também a introdução das novas formas "modernas" da produção. Dirce é uma das trabalhadoras antigas da empresa, contratada em 1991 ainda menor de idade, aos 17 anos, que começou a trabalhar na fábrica de Itapecerica da Serra e segue até hoje trabalhando em Cajamar.

Quando da mudança da fábrica, a empresa realizou um programa de demissão voluntária (PDV), destinado especialmente aos trabalhadores que não estivessem satisfeitos com as modificações em seu deslocamento e em seu cotidiano ocasionadas pela mudança da cidade onde trabalhavam. Dirce foi parte do contingente que aderiu ao PDV naquele momento. Porém, 4 anos depois, ainda em contato com colegas na Natura, soube de um processo de contratação na empresa e decidiu voltar, por conta do salário, dos benefícios e também porque, a esta altura, já havia sido organizado pela Natura um sistema de transporte via ônibus fretados, facilitando seu deslocamento, que leva e busca os trabalhadores a diversos pontos da capital, da Grande São Paulo e da Região Metropolitana de Campinas (a planta de Cajamar, às margens da rodovia Anhanguera, está estrategicamente localizada entre as duas mais importantes regiões metropolitanas do Estado de São Paulo, o que facilita o recrutamento de mão-de-obra bem como a logística de distribuição de seus produtos e o recebimento de insumos).

Entre as principais mudanças apontadas por Dirce estão a introdução de novas máquinas, que reduziram o número de trabalhadores por linha e algumas atividades 
manuais, mas, sobretudo, a forma como os trabalhadores se relacionam em suas atividades cotidianas na produção.

"Lá [na fábrica de Itapecerica da Serra] era bem simples, né? Um galpão inteiro e várias linhas. Tudo bem simples, um telhado de Brasilit que, quando chovia, sujava todas as linhas. Só tinha duas salas separadas, que era onde fabricava Chronos [uma linha de produtos da Natura] e outros produtos que tinham contaminação. Os demais eram todos juntos. Hoje nós temos três fábricas, né? Fábrica de perfumes, cremes e maquiagens. Eu sou do Rio da Prata, cremes e maquiagens (...). E era tudo, assim, junto. Era bem legal. Aí veio para cá. É diferente, né? Automatizou tudo. Lá [em Itapecerica], por exemplo, uma linha de batom, você tinha que colocar 18 pessoas para rodar uma linha de batom. Hoje, (...) com 4 pessoas, você roda uma linha e produz muito mais do que se produzia antes com 18 pessoas. Mas era muito gostoso lá. Aqui mudou bastante, facilitou muito o trabalho. (...) Era tudo muito manual.

(...) Lá era tudo muito junto. Era outro tipo de empresa. Aqui mudou bastante. As pessoas cobram mais. Mudou em que sentido? (...) Aquele negócio de estar todo mundo junto hoje não existe mais. Era uma coisa mais familiar.

Hoje é melhor. Automatização, a empresa tem algo a mais para oferecer. As pessoas são mais capacitadas. Hoje você vê na linha as pessoas são bem mais formadas. $\mathrm{Na}$ época [anterior], nem segundo grau as pessoas tinham... Hoje, você chega na linha e uma ou outra tem segundo grau. A maioria é formada [no ensino superior]”.

Dirce, desse modo, aponta o aumento da escolarização dos trabalhadores como outra das características da nova fábrica de Cajamar. Sua própria trajetória demonstra-o: auxiliar de produção, anos depois de ingressar na empresa, ela matriculou-se no ensino superior e graduou-se em Gestão Ambiental. Apesar disso, a progressão salarial e a promoção, na Natura, não estão diretamente relacionadas ao fato de obter formação superior. $\mathrm{Na}$ verdade, ambas estão condicionados, entre outras coisas, ao avanço no desempenho na avaliação "Meu Caminho"21.

Mônica, auxiliar de produção na fábrica "Rio São Francisco", é uma jovem trabalhadora, de 22 anos, que há 4 está na empresa. Ela não vivenciou a introdução das mudanças na fábrica e na produção, sobre as quais falou Dirce, e assim descreve a combinação, que ocorre em suas atividades cotidianas, entre a produção automatizada e algumas das tarefas manuais pelas quais é responsável.

"Na verdade, o envase é tudo na máquina. Tudo maquinário. Existe uma espécie de tubulação, que sai lá do retanque, lá de cima, onde os manipuladores trabalham, e desce para a linha de envase. Na linha de envase tem um equipamento que vai envasando dentro dos frascos, que é onde a gente abastece. Aí, envasado o produto, são colocadas as válvulas... Aí, vai depender de que produto é. Por exemplo, um Kaiak [perfume], coloca as válvulas, coloca a tampa. Por exemplo, o acionador, na linha que eu trabalho, é manual. Aí a gente coloca. Depois é encartuchado, depois é celofanado e depois é colocado na caixa. Aí a parte de colocar na caixa também é manual”.

\footnotetext{
${ }^{21}$ Sobre a qual a dissertação se debruçará no capítulo 3, bem como sobre o estímulo da empresa ao aumento da escolarização e suas consequências no interior do grupo operário.
} 
No que se refere às mudanças mais importantes na produção, pode-se falar além das já mencionadas células, metas e PLR - do sistema TPM, Total Productive Maintenance, que está na linhagem do "modelo japonês". O TPM foi introduzido na nova fábrica de Cajamar em conjunto com as células semiautônomas. De acordo com Ludmila Abílio (2011), o TPM é

"uma organização da fábrica voltada para a eliminação de problemas, tendo como objetivo a máxima eficiência da produção. 'Zero acidente, zero de defeito, zero de quebra/falha' definem as metas, que envolvem desde os trabalhadores do chão de fábrica até os gerentes. Assim, trabalhadores tornam-se responsáveis por monitorar e criar soluções para o aumento da produtividade e redução dos prejuízos" (ABILIO, 2011: 56).

Susana Diniz assim definiu como operam as células semiautônomas, organizadas de acordo com os princípios do TPM:

"A gente criou um conceito que a gente chama de células semiautônomas. Na produção, estas células se autogerenciam, elas são grupos, elas podem ser menores ou maiores, dependendo da linha em que elas estão de produção. Elas todas [as trabalhadoras e trabalhadores] têm que passar por todas as estações, ou seja, aprender todos os processos e elas combinam, então, quando todo mundo está pronto, qual é a atividade [a ser realizada por cada um na célula num dado turno]. Quando todo mundo está pronto, têm algumas pessoas que podem fazer algumas funções e outras não. É certificado, tem um crachá comparado, se ela não tiver feito outro treinamento, não passou na prova física, prática, ela não pode fazer aquela operação. E eles se autoavaliam, né? Eles não têm um chefe para avaliar. Eles se autoavaliam para ver como foi a questão do grupo.

(...) São processos que vieram juntos [células semiautônomas e TPM], né? O TPM é um processo que vai trabalhando vários pontos de produção, desde o processo de Recursos Humanos - então, como lidar, fazer, desenvolver (...) -, toda a parte que vai criar processos e procedimentos das ITs (as Instruções de Trabalho), como se faz cada coisa, como controla, como faz perdas, como faz o processo, como se reprograma... Então, na verdade, ela é um orientador grande, com foco em qualidade, de forma que a gente vá produzir a melhor coisa e não esquecer dentro dos processos. Tem todo um plano de comunicação, então, é um modelo que a gente segue, de forma que seja único para todas as fábricas (...) e que a gente monitora desempenho, desenvolvimento e produtividade em cima de um único processo padrão. E isto é obviamente em virtude do crescimento [da empresa] (...). Você tem que garantir controle de qualidade, um mesmo processo. (...) Este é o pressuposto do TPM: cada um é responsável pelo seu processo”.

Ao falar de suas atividades diárias na produção, Norma, operadora de máquina na fábrica "Rio da Prata", mostra como os princípios do TPM organizam a produção na prática. Há 15 anos na empresa, Norma foi contratada em 1999 e vivenciou o processo de transição da fábrica de Itapecerica para Cajamar, ocorrido entre 2000 e 2001. Tendo iniciado na empresa como auxiliar de produção, técnica em Química, passou a ser operadora de máquina e estuda Farmácia numa faculdade privada com vistas a obter uma promoção.

Norma mostra como, em suas tarefas, não lhe cabem apenas as atribuições da operação das máquinas de envase. O TPM implica que Norma seja responsável por uma 
série de outros procedimentos: ela deve, em primeiro lugar, receber do gestor, responsável por toda a fábrica "Rio da Prata", a programação para sua célula, as demandas de produção da jornada, que são determinadas pelas metas gerais da empresa, mas também por flutuações circunstancias da produção que dependem do fluxo de encomendas das consultoras ou mesmo de mudanças episódicas ocasionadas pelo lançamento de um novo produto. Além disso, ela deve acompanhar o desempenho da máquina e será a primeira responsável, antes de buscar auxílio com algum mecânico ou eletricista, por encontrar soluções para algum eventual problema que nela se apresente. A produção de uma série de registros e gráficos que monitoram a produção também é de responsabilidade de Norma. Através deles, o desempenho da produção será medido e o acompanhamento do alcance das metas pelos analistas, determinante para que se possa ganhar a PLR integral, realizado.

"O gestor vem, passa a programação da linha numa folha e a gente vai tomando as nossas atitudes. Tem um canal aberto entre a gente. Eu passo as coisas para ele, ele passa para a gente. Às vezes minha visão não está legal, ele barra a minha visão. É sempre pensando na qualidade e na produtividade com segurança. [A programação enviada pelo gestor] é diária. Não só diária, como pode acontecer o tempo todo, dependendo da necessidade e do que está acontecendo no processo. (...) A gente responde pelas nossas metas. Cada linha tem a ferramenta TPM, onde a gente faz uns trinta gráficos e todas são metas: algumas mensais, outras diárias, algumas quinzenais. Então a gente tem que correr atrás de atingir essas metas (...).

Eu lido com aquele rio, com aquela máquina. A gente toma conta ao redor daquele rio, daquele trecho. Então, tudo que vai estar saindo, entrando na máquina a gente, operador, responde para os analistas. Eles passam a responsabilidade e tudo o que estiver contra ou a favor da linha a gente toma conta e passa o retorno para eles. (...) Se vai atingir, se não vai atingir as metas (...).

São várias [tarefas em seu trabalho diário]. A gente faz todo o processo de controle de qualidade do produto acabado. A gente faz todo o processo de abertura de documentação, tanto física como no computador. A maioria é no computador, mas tem alguns que é físico, que confronta os dois depois. (...) A gente faz setup na máquina, a gente opera, a gente multiplica o nosso conhecimento para os auxiliares. A gente faz tipo um treinamento, fica treinando os auxiliares que vêm trabalhar conosco. A gente fica treinando eles para ficar eficaz, né, para estar atuando juntamente com a gente, somando e... É que são várias, né, não dá para lembrar de todas”.

Mariano, mecânico de manutenção na fábrica "Rio da Prata", trabalha há 10 anos nesta função. Em seu relato, descreve as atividades que desenvolve em sua célula "Rio Tietê", composta por mecânicos, ao mesmo tempo em que também trata da multiplicidade de tarefas com as quais deve lidar em seu cotidiano.

"Nossa célula [Rio Tietê] é só de manutenção. É a que faz manutenção em todas as outras células. (...) A gente roda pela fábrica [Rio da Prata] toda. Dentro da fábrica, fora da fábrica.(...) Cada linha tem um padrinho. O padrinho que é o mecânico 
responsável. A gente atende todas as linhas, mas uma linha tem um mecânico que é o responsável por dar toda a assistência aquela linha ali, responder pelos indicadores dela. Eu sou padrinho de uma máquina de envase. (...) Tem o programador, que faz a programação (...). [No início da jornada] Já tem a programação do que a gente vai estar fazendo. Então, a gente chega no nosso dia-a-dia comum de atender as linhas e, se tiver algo programado, a gente se divide: você vai para tal lugar, você vai para tal lugar, é bem direcionado. Tem o sistema, que é o SAP. Pelo sistema, a gente controla o tempo de parada de máquina, a disponibilidade de máquina, é calculada pelo SAP. SAP é o sistema que tem na Natura, o sistema de gerenciamento. Este sistema, tudo o que é feito na máquina, quando para a máquina, o programa vai lá e dá uma nota e aquela nota o sistema vai contabilizando, tipo um cronômetro, vai contando lá. (...)

A gente faz atendimento de linhas. É responsável por dar assistência aos operadores na linha e a gente trabalha em cima de análise, PDCA, então, são as ferramentas que a gente usa no dia-a-dia, como o TPM, resolução de etiqueta, é o que a gente faz no dia-a-dia, atender fornecedor, desenvolver componentes novos para os equipamentos, fazer melhoria nos equipamentos que chegam e vêm os equipamentos de fora, mas sempre precisa de alguma melhoria. Então a gente entra nessa área, para desenvolver novas ferramentas para auxiliar no equipamento ali para poder ter alguma melhor produção. Ou, se tem alguma coisa que pode causar desperdício de material, que vai impactar no meio-ambiente, então a gente já trabalha em cima para poder reduzir aquilo ali ou eliminar. (...) A gente faz manutenção nas máquinas, que já são usadas para deixar o produto pronto. (...) A gente trabalha na área de envase".

Os princípios do TPM, a preocupação com a manutenção e ampliação da produtividade, precauções contra o desperdício e questões relacionadas à preservação ambiental: tudo isto passa a compor a miríade de atividades prescritas aos trabalhadores da nova planta da Natura de Cajamar. Na fala do mecânico Mariano, é possível notar concretamente vários dos quesitos apresentados por Susana Diniz da orientação, pelo Total Productive Maintenance, da produção da Natura em sua nova fábrica, destinados a garantir a manutenção do crescimento da produtividade, da dimensão de mercado e dos lucros da empresa. O discurso operário, desse modo, parece incorporar preocupações típicas da direção da empresa e de seus acionistas, inclusive na percepção dos saberes e tarefas específicos à realização do trabalho cotidiano.

A expectativa de polivalência, na célula, também se refere à necessidade de autocontrole e controle do outro, com a saída de cena de um superior identificável imediatamente. Mariano assume, em sua célula, a função de monitor. Além do controle dos trabalhadores por seus pares na célula, típico das formas de produção pós-fordistas, o monitor assume tarefas de controle e organização da produção e do trabalho, ampliando a já elástica gama de funções pelas quais precisa responder. A expectativa que a empresa tem de autocontrole do grupo operário através da introdução das células e o papel do monitor na célula podem causar, como mostra o relato de Mariano, algum desconforto e eventualmente algum tipo de conflito cotidiano no interior do grupo. 
"A gente tem programa de semiautonomia e nas células têm padrinhos de performance, monitores de performance, segurança e monitores de pessoas e quando tem algo que está, assim, prejudicando a equipe [fala sobre dificuldades para alcançar as metas ou queda de produtividade por parte de algum dos trabalhadores na célula], a gente - eu, por exemplo, sou monitor de pessoas - procura chamar a pessoa e já orientar a pessoa, antes de passar para o superior. A gente procura ter uma conversa com a pessoa, procura se controlar, ver o que está acontecendo ali, tentar resolver, antes de passar. Se não conseguir, através de diálogo, resolver com a pessoa ali, então é encaminhado para o superior: olha, está acontecendo algum problema ali, tal, a gente precisa de uma ajuda. (...) Às vezes, causa desconforto porque esse bate-papo que a gente vai ter com a pessoa é um feedback que a gente vai dar para a pessoa e tem muitas pessoas que não aderem a essa ideia de feedback: ah, você tá querendo falar para mim, não é meu chefe! Então, fica uma coisa meio... Gera um desconforto, sim. O superior é em último caso porque na maioria das vezes a gente consegue controlar entre a gente mesmo. Tem um ou outro que não dá, mas aí a gente troca uma ideia, deixa pra lá porque o cara tá nervoso, vai lá e conversa com o cara de novo. Daí consegue controlar. Mas é raro levar a situação para o superior, só se o cara tá faltando muito, aí não tem como. Se você conversa e a pessoa não tomar posição, aí já não é mais na esfera da gente, é como na hierarquia de qualquer empresa, que é com o superior mesmo".

Na opinião de Mariano, no entanto, as mudanças na produção, em comparação com o que ocorria antes, foram benéficas no que se refere à relação entre os trabalhadores e as chefias. Caberá abordar, à frente ${ }^{22}$, o significado desta percepção para o grupo de trabalhadores e para a empresa que conscientemente introduz tais mudanças.

"Eu creio que assim é uma maneira boa [de organizar a produção e o trabalho] porque já tivemos experiência de formas anteriores que não eram assim. Aí ficava uma coisa: só quando você tinha algum problema você ia conversar com o líder de produção, na época. Aquele contato é muito difícil e hoje, dessa forma, as metas ficam mais claras, a gente vê que a forma de chegar a essas metas a gente não precisa ficar o tempo todo com o líder ou o analista ali do lado, você já consegue controlar. Foi bem legal essa implantação do gerenciamento na Natura assim”.

É possível, então, nas falas de Norma e de Mariano, observar as consequências do TPM, na verdade uma atualização dos princípios do "modelo japonês" (HIRATA, 1993) - também consagrado na literatura, por exemplo, como "especialização flexível" (PIORE e SABEL, 1984), "acumulação flexível” (HARVEY, 2011), pós-fordismo ou just in time - na atividade cotidiana dos trabalhadores. Beaud e Pialoux (2009) abordam os efeitos sociais e simbólicos do controle realizado pelos pares no interior do grupo operário. Os autores narram, eloquentemente, em sua discussão a respeito das “contradições do jovem monitor", uma espécie de drama pessoal ilustrativo de como as tarefas relacionadas ao controle dos colegas levam um jovem trabalhador, que assume a tarefa de monitor na Peugeot-Sochaux, quase ao colapso psicológico. Os conflitos

\footnotetext{
${ }^{22} \mathrm{O}$ que se pretende fazer mais detidamente no capítulo 5, destinado às conclusões da dissertação.
} 
ocorrem principalmente com colegas da geração operária mais antiga, acostumados ao embate cotidiano com as gerências e com a formulação de estratégias para burlar o controle, que rejeitam as novas imposições impessoais do fluxo e o papel do monitor como organizador coletivo das atividades, após as mudanças na produção introduzidas naquela empresa. Como resultado, o monitor acaba tendo de assumir, requisito de sua função, muitas das tarefas que seus colegas recusam-se a fazer por não aceitarem o aumento da produtividade $\mathrm{e}$ as novas disposições empresariais. Não apenas a solidariedade no interior do grupo operário foi sendo aos poucos erodida, através do estímulo ao conflito geracional, por parte da empresa, e da desqualificação social e simbólica da velha geração ao obrigá-la a responder a jovens monitores, seus pares na produção. A introdução do monitor foi uma estratégia empresarial para dificultar o "corpo mole" ou a recusa ao ritmo, típica forma de luta de classes na produção. Os monitores, no entanto, foram submetidos a intensa pressão, seja pela intensificação brutal de suas tarefas e atividades, seja pela confrontação permanente, ora de seus pares ora da gerência.

É possível, também, através dos relatos de Susana Diniz, Norma e Mariano, que mostram o modo como opera o TPM na Natura, recolocar em questão a caracterização de Durand (2003) sobre o "fluxo tensionado" orientando a produção flexível e fazendo com que os operários não mais identifiquem o superior, a gerência ou o controle capitalista como os responsáveis pela intensificação e pela exploração, mas antes as demandas impessoais do fluxo produtivo, destinadas a garantir a lucratividade e a produção em empresas financeirizadas, nas quais o antigo patrão pulveriza-se numa miríade de acionistas desconhecidos. Manter o fluxo tenso torna-se um imperativo de todos os trabalhadores para assegurar seus empregos e muitas vezes a localização da própria planta, haja vista a mobilidade ampliada do capital. Trata-se da mobilização do trabalho coletivo para atender às demandas de acumulação do capital, através do comprometimento do trabalhador individual com as metas e expectativas de produção e realização de lucros das empresas. A "pilotagem pelo fim" organiza e articula a produção nas células, as encomendas de subcontratadas - nas quais a precarização do trabalho amplia-se - e a possibilidade de atender às demandas do mercado em tempo real.

$\mathrm{Na}$ Natura, as encomendas das consultoras determinam em larga medida as imposições do fluxo produtivo. O picking é o centro de logística no qual se conectam a 
produção e a rede de mais de 1,5 milhão de consultoras que vendem os produtos da empresa. Conforme sublinharam os gerentes Roberto Andrade e Pedro Lima, cujas entrevistas serão objeto de discussão na seção abaixo, a inauguração do novo picking no quilômetro 13 da Anhanguera viria acompanhada de inovações no que se refere à coordenação entre vendas e produção. Em particular, eles falaram a respeito do desenvolvimento de uma nova ferramenta online que permitiria não apenas às consultoras, mas também a suas clientes, fazer encomendas. Além do uso da internet, a novidade está em explorar a rede de contatos de cada consultora, permitindo que uma cliente encomende diretamente ao site da Natura um produto do catálogo, atrelando o pedido ao perfil da consultora que lhe atende normalmente, mas podendo optar por receber a encomenda em casa com ou sem a mediação física da consultora. Desse modo, é como se a comissão da consultora com a venda, aos poucos, passasse a ser uma espécie de "aluguel" de sua rede de contatos real e virtual. Inovações deste tipo servem para ampliar as vendas e garantir a manutenção do "fluxo tensionado" da produção. Porém, aqui, pode-se falar na inauguração, aos poucos, de uma espécie de "fluxo tenso online", organizado pela empresa de forma a garantir o máximo de produção e a diminuição do tempo necessário para a distribuição das mercadorias em seu sistema de venda direta.

É possível ver, assim, a pressão individual pela realização das metas e a responsabilização crescente do trabalhador por uma série de tarefas, justificada no discurso empresarial como forma de autonomia e polivalência, como na verdade intensificação dos ritmos e racionalização de custos com a diminuição de funções. As consequências disto, inclusive no aparecimento de casos de Lesões por Esforços Repetitivos (LER) em diversos trabalhadores, serão objeto de discussão no capítulo 3.

As novas técnicas de organização do trabalho e da produção, introduzidas em Cajamar, foram responsáveis por um grande aumento da produtividade e pela competitividade internacional da empresa. No entanto, a intensificação do trabalho e a pressão individual, também estimulada pelas recompensas materiais (como a PLR e os 'prêmios'), fazem com que muitos cheguem à conclusão de que, do ponto de vista da fadiga e das exigências, a velha fábrica taylorista de Itapecerica não tenha realmente terminado. "Itapecerica e Cajamar são a mesma coisa", resume Marilda, uma trabalhadora demitida com LER durante período de reabilitação. Marilda, que buscava à época da entrevista sua aposentadoria por invalidez, parece demonstrar a proliferação de 
casos de doenças do trabalho como consequência da introdução das formas de produção flexível.

As células semiautônomas e a organização da produção de acordo com os princípios do TPM, combinadas com o regime de metas, são muitas vezes apontados como sinônimos de intensificação do trabalho.

"Você produz 1700 [cartuchos] num dia, no outro eles querem 1800. A linha é assim. É pauleira porque, como as máquinas mudaram, a produção é maior (...). Isso já em Cajamar porque, quando veio de lá eles foram mudando as máquinas, mudando, mudando para melhor para eles e não para os trabalhadores” (Entrevista com Marilda).

O regime de metas, coletivas e individuais, adotado pela empresa, é visto como um dos grandes responsáveis pela intensificação, pela introdução da concorrência no seio do grupo operário e pela vulnerabilidade às doenças do trabalho, em especial à LER.

As vicissitudes da implantação das células semiautônomas e do TPM, e as dificuldades de adaptação dos trabalhadores às exigências empresariais são narrados por Susana Diniz num relato bastante significativo a respeito dimensão intencional da empresa na busca de alguns dos efeitos da introdução do controle pelos pares na célula, das metas e da autoavaliação pelo grupo. O objetivo parece bastante claro: fazer com que os trabalhadores aceitem - e não apenas isto, mas reconheçam como positivas - as mudanças na produção.

“Hoje, já está um processo muito estruturado [a organização do trabalho por células e metas], está muito já arraigado. No começo, tivemos algumas coisas. Então, por exemplo, quando a gente foi implementar isto e a gente fez avaliação de desempenho e eles se autoavaliavam todo mundo tirou 10. Então é natural porque a gente tem esse padrão de ser humano brasileiro [rindo] que é ser bonzinho e tal. E a gente aos poucos foi treinando, foi desenvolvendo, dizendo assim: olha, não produziu, você também está ganhando menos, esta fábrica não está entregando resultado porque umas células não entregaram, então não é bem assim... Ao longo do tempo, foi ganhando maturidade e hoje eles se autoavaliam e avaliam o outro com mais critério. Ainda é um processo benevolente? Sim. Mas avaliam com mais critério do que avaliavam antes. Tem uma característica Natura e uma característica Brasil que é isto. É mais benevolente.

[No início da implantação das células] começou um estresse porque as pessoas queriam um chefe. Nas pesquisas de clima que a gente faz do focus group, elas diziam: 'não, não tá bom, preciso de alguém'. E a gente, num primeiro momento, até falou: não, fizemos errado, tem que pôr gente. E aí a gente mesmo se cutucou dizendo assim: não, nós estamos aqui na verdade querendo conservar algo que a gente não quer conservar. Porque se eu tiro e coloco o chefe de volta eu estou abrindo mão de estipular um novo modelo de autoconhecimento, de evolução contínua e que naquele momento era difícil. Mas que, se eu não me posicionasse mais fortemente, eu também não conseguiria fazer a mudança. Porque se eu escuto direto o que eles me dizem, não necessariamente eu estou fazendo o melhor. E aí a gente decidiu que a gente ia, na verdade, ouvir mais a 
nossa razão e dizer: nós precisamos de mudança. Então, vamos ficar firmes na nossa posição! (...) Agora, se isto faz uma grande diferença, eu não sei dizer. No sentido delas [as trabalhadoras e trabalhadores]. Eu tenho certeza de que elas não gostariam de voltar no modelo anterior porque hoje elas têm muito mais desenvoltura, crescimento, enfim, têm muito mais autonomia pela sua carreira do que elas tinham antes".

Num caso que parece significativo do que aqui se entende por desestruturação do grupo operário, nas trilhas de Beaud e Pialoux (2009), será discutida no capítulo 3 a demissão de 33 trabalhadoras, boa parte das quais em reabilitação, portadoras de LER. $\mathrm{Na}$ Natura, meses antes de que a situação ganhasse alguma repercussão na imprensa e chegasse até mesmo à Câmara dos Deputados, o Sindicato dos Químicos de Osasco já editava boletins chamando a atenção para a questão ${ }^{23}$.

"Uma coisa que está preocupando muito, que está ganhando cada vez mais corpo nos acordos de PLR é a questão das metas individuais. (...) Uma coisa é você ter uma meta coletiva em que um trabalhador pode compensar a dificuldade do outro. (...) É mais fácil você controlar o cara individualmente do que você controlar o todo. Então, você chega lá, tem a meta coletiva, normalmente relacionada ao resultado da empresa, só que tem a meta individual, que é aquela em que você vai 'sentar com o gestor' bonito pra caramba, né, 'sentar com o gestor', que em outras palavras você poderia dizer sentar com o capataz - e você vai acertar com ele a meta. Uma coisa maluca. (...) Você vai dizer para ele qual é a meta, qual é o compromisso que você está assumindo!” (Entrevista com Amarildo Silveira, diretor do Sindicato dos Químicos de Osasco).

\footnotetext{
O modo como a Natura articula a proposição de metas, a PLR e mesmo "prêmios" incidentais são um exemplo notável de individualização do trabalho, competição entre os pares no grupo e desmonte da solidariedade coletiva, típica da classe operária.
}

\section{Box 1: Principais funções na produção ${ }^{24}$}

\footnotetext{
${ }^{23}$ Em abril de 2010, durante as negociações para definição das metas anuais da PLR, o boletim do sindicato relatava o recrudescimento das negociações e a ampliação das metas. Em maio de 2010, o boletim especial "Quem está bem!?" (ironia com o slogan "Bem estar bem", da Natura) tratava exatamente da intensificação da produção requerida pela empresa no período, do aumento nos casos de LER na Natura e sua relação com as exigências do TPM.

${ }^{24}$ Como a empresa proíbe a entrada nas áreas de produção da planta, a descrição destas principais funções, que não esgota todas as posições assumidas na produção, foi realizada a partir dos relatos oferecidos pelos trabalhadores a respeito de suas tarefas cotidianas e das atividades de seus colegas. Agradeço em especial a Antônio, que atua há mais de 20 anos na Natura, e auxiliou a produção desta síntese.
} 
Auxiliar de produção - responsável por auxiliar o operador de máquina, acompanhando, fornecendo e mantendo os materiais, como por exemplo as embalagens de envase, nos locais e quantidades adequadas para a manutenção do fluxo. Também pode ser responsável pelo encaixotamento dos produtos finalizados. O auxiliar pode assumir ocasionalmente, na ausência temporária do operador, algumas das funções do último.

Operador - responsável pela operação das máquinas e linhas de envase, o operador acompanha o cumprimento da programação, a manutenção do ritmo, as variações ocasionais na produção durante a jornada, além de produzir gráficos, que monitoram a produtividade e a consecução das metas, e adotar procedimentos primários relativos à manutenção e ao reparo eventuais no equipamento.

Manipulador - responsável pelas atividades de mistura de insumos e componentes necessários, por exemplo, à produção de cremes, loções, desodorantes e perfumes. Nas fábricas "Rio São Francisco" e "Rio Amazonas", os manipuladores atuam na área superior da fábrica, de onde a mistura final desce por meio das tubulações, com auxílio da gravidade, às máquinas e células de envase e embalagem.

Preparador - responsável pela ligação entre os tanques de mistura e os "rios", ele realiza as atividades de setup da máquina, ou seja, a preparação das máquinas para receber misturas diferentes relativas a tipos diversos de cremes, loções, perfumes ou óleos envasados nos rios. O preparador trabalha na parte inferior das fábricas "Rio São Francisco" e "Rio Amazonas".

Mecânicos e eletricistas - responsáveis pelas atividades relativas à melhoria de desempenho, preparação, manutenção ou reparo de máquinas e equipamentos nas fábricas.

\section{A abertura de capital e internacionalização da Natura: a criação de uma empresa cosmética global de capital nacional}

Entre o final dos 90 e começo dos anos 2000, houve um período de assédio à empresa. Investidores estrangeiros tinham interesse em adquirir a companhia. Os controladores viajaram ao exterior e tomaram contato com especialistas e donos de outras empresas da área. Chegam à conclusão de não vender a Natura, mas de reorganizá-la para ampliar sua produção e o mercado num momento em que a empresa parecia haver alcançado seu limite. A marca foi relançada e construção de nova fábrica tornou-se uma prioridade.

"A necessidade de ter tudo integrado num prédio icônico que expressasse as crenças na transparência, como você pode ver pelo tanto de vidro, nas relações, porque 
tem todo o corredor de visitação para as pessoas virem, conhecerem, nos visitarem, verem o que acontece... Então foi por isso. Obviamente, pela necessidade de construir uma nova etapa da Natura, ter um marco dessa nova etapa, de uma marca renovada e de ter um prédio icônico que reunisse tudo, distribuição, produção, administrativo, etc. Mas um tempo depois já estava pequeno de novo para acompanhar o ritmo de crescimento da empresa. E é por isso que a gente vai abrindo outras frentes".

Renato Andrade assim explica o planejamento que envolveu mudanças profundas na Natura, a inauguração da nova fábrica em Cajamar, a introdução de novas máquinas e as mudanças na organização do trabalho e da produção. Trabalhando há 10 anos na empresa, Andrade é graduado em Ciência Política e gerente de assuntos corporativos. Contratado para criar a área de relações governamentais, hoje é responsável pelos relatórios anuais da empresa, por suas relações com a imprensa e pela assessoria da presidência, do CEO e dos controladores. Em entrevista com Pedro Lima, gerente de parcerias e alianças ${ }^{25}$ da Natura, graduado em Engenharia de Produção, eles abordaram uma série de aspectos da expansão da Natura em sua nova fase.

No geral, em suas respostas, Renato Andrade aborda as questões de um âmbito político ou mais afeito ao que se poderia chamar de discurso oficial da empresa. Já Pedro Lima, oriundo do mercado financeiro, expressa-se muitas vezes com os jargões desta área, revelando, em diversos momentos, uma certa disposição a abordar o aspecto "real" ou "do jogo" envolvido nas questões. No que disse ser uma "posição individual", Lima avalia desse modo o atual cenário de negócios no país:

"O ponto em que nós estamos é um ponto crítico. (...) Eu acho que esses últimos 8, 10 anos foram completamente inúteis do ponto de vista de garantir que certas reformas fossem feitas para garantir crescimento. E para garantir reformas que todo mundo conhece há muito tempo: tributária, trabalhista, mais recentemente, a política e tudo isso".

Para ele, a estabilização econômica e a ampliação do consumo foram conquistas da sociedade que começaram no governo FHC e cresceram no governo Lula. As empresas se beneficiaram disto e o crescimento da Natura é em parte resultado dessas transformações econômicas no Brasil. Andrade, por sua vez, explica que o mercado de cosméticos apresenta uma característica peculiar: quando a economia se encontra em dificuldades, o sistema de venda direta de cosméticos segue vivo e pode garantir crescimento, já que as pessoas buscam novas fontes de renda, em especial "sem amarras". Quando a economia cresce, o cenário seria ainda melhor porque os recursos adicionais disponíveis ampliam a venda de cosméticos.

\footnotetext{
25 "Parcerias e alianças" é o nome que a área de fusões e aquisições recebe na Natura.
} 
Por isso, teria havido em sua opinião dificuldade para que a Natura definitivamente tomasse a decisão de internacionalizar-se. O tamanho de um país como o Brasil seria como uma vantagem e, ao mesmo tempo, um inibidor, uma "faca de dois gumes": o fato de aqui milhões falarem a mesma língua, conviverem em uniformidade cultural e terem à disposição meios de comunicação capazes de atingir amplos contingentes tende a levar as empresas brasileiras a se focarem neste grande mercado. Seria, portanto, uma dificuldade voltar-se ao exterior. Apesar de toda a expansão internacional da Natura, os resultados, para eles, são ainda tímidos: apenas 10\% da receita vêm de fora do Brasil, enquanto $100 \%$ do lucro são garantidos pelas operações nacionais.

A expansão internacional da Natura, segundo descrevem Andrade e Lima, ocorreu em três "ondas". A primeira ocorreu nos anos 80 e 90. Trata-se de uma onda "amadora", que ocorreu sem planejamento, a partir do interesse que alguns distribuidores tinham de levar produtos da Natura para outros países ou de uma busca da empresa ainda tímida e inicial por ampliar as operações e vendas a outros países. Nesse período, tentou-se de modo frustrado iniciar operações em Portugal, depois abandonadas, e abertura em Chile e Peru, onde atualmente o negócio já atingiu margem de equilíbrio. Na Argentina, onde se iniciaram operações também nesta "onda", a empresa hoje é top five nos rankings de top of mind. Também se realizou um acordo comercial na Bolívia com parceiro local, que distribui ainda hoje produtos da empresa.

A abertura de capital da Natura, ocorrida em 2004, três anos depois da inauguração da planta de Cajamar, marca a segunda "onda" de internacionalização da empresa, ocorrida com mais planejamento. Naquele ano, foram abertas atividades na França e no México. Sua característica comum à "onda" anterior é que esta expansão também se baseou em operações próprias. A abertura de flag ship store (loja-conceito) na França ajudou a alavancar a marca no que Andrade chama um "mercado premium". Houve um forte reforço na percepção da marca Natura, como consequência, no próprio mercado brasileiro. Como parte desse esforço, inaugurou-se um laboratório também na França e, em 2006, foram banidos os testes em animais em toda a cadeia. Esta "onda" levou as operações da Natura à Colômbia e à Venezuela em 2005, mas, em 2010, as atividades neste último país foram encerradas. Colômbia, México e Argentina consolidaram-se como mercados externos muito importantes para a companhia. 
"Nessa segunda etapa já existia uma visão muito mais profissional sobre esse esforço de internacionalização. (...) Muito dessa visão profissional estava fundamentada na crença, que existe até hoje - e é uma crença que motiva a Natura a aportar esforços na internacionalização -, de que a marca da Natura é muito maior do que o negócio que a Natura tem hoje. Porque a marca da Natura, apesar de não ser conhecida em mercados onde não está presente, como os EE.UU., tem um apelo para o consumidor americano assim como teria um apelo para consumidores em outros mercados. Porque a marca da Natura fala de valores universais, representa valores universais de uma forma muito legítima. O cuidado, por exemplo, com a Amazônia, com os ingredientes que são extraídos da Amazônia, tudo isso tem apelo para esses consumidores. Por isso, a gente acredita que a marca da Natura, representando isso de forma legítima, tem um tamanho em potencial muito maior do que o business que tem hoje”.

A dimensão adquirida pela empresa, o relativo sucesso da segunda "onda" e o potencial, do qual fala Pedro Lima acima, levaram a grandes discussões de estratégias de longo prazo para a expansão internacional da companhia a partir de 2006. Tal foi necessário, em particular, porque o cenário externo viria a modificar-se radicalmente. $\mathrm{Na}$ época da ida ao México, pensou-se em levar a marca Natura a outros países, adotando o sistema de venda direta e a busca de crescimento orgânico. Seria necessário mandar a estes países profissionais brasileiros. "Levar a Natura começando do zero", como afirma Roberto Andrade.

\footnotetext{
"Veio a crise e isso afetou os nossos planos não por medo ou conservadorismo, mas porque a crise estava acontecendo justamente naqueles países foco da nossa entrada. Ou seja, você entrar em um ambiente instável... E a gente tinha a América Latina, nosso principal mercado, estável e, naquele momento, com a percepção de imune à crise, como é efetivamente até hoje. Tem sido. Então, a decisão foi justamente essa: bom, temos um mercado estabelecido onde a economia vai muito bem e estávamos estudando mercados onde a economia estava indo para o buraco. Então, foi essa a decisão. E não por medo da crise, mas por ver que a crise estava acontecendo naqueles lugares onde a gente tinha intenção de entrar".
}

A situação que descreve Andrade ocorreu num momento em que estavam nos planos a abertura de operações nos EE.UU. e a entrada definitiva na Europa, através do Reino Unido, além da chegada à Rússia. No entanto, foi preciso abandonar "temporariamente" tais expectativas por conta da crise econômica de 2007/08. Veio um momento de algumas dificuldades para a Natura que, após algumas reformas, especialmente administrativas, "volta a crescer satisfatoriamente". A estratégia de internacionalização é reavaliada. Inicia-se o planejamento da prática de "parcerias e alianças", ou seja, expansão dos negócios da companhia através da aquisição de outras empresas do setor, sem necessariamente levar os produtos e a marca Natura aos mercados onde estas se localizam.

Para Pedro Lima, o sistema de venda direta, de "crescimento orgânico" das operações “a partir do zero", é difícil. Os casos de Argentina e Chile demoraram muito 
para trazer retorno e puderam desenvolver-se em circunstâncias específicas. "Nossos acionistas não têm mais tanta paciência", afirma. "A marca Natura é muito grande, mas por seus valores, por sua essência e pela dificuldade de crescimento orgânica, a marca Natura não consegue acessar todos os perfis de consumidores que a corporação Natura gostaria de atingir". Existe espaço, avalia, para que a corporação seja multimarcas.

Esta avaliação abriu a "terceira onda" de expansão internacional, que teria começado com a aquisição da empresa australiana AESOP em $2012^{26}$. Uma marca que, para Lima, tem grande potencial de expansão e que não "competiria com Natura". Não há planos para que a marca Natura entre na Austrália e nem de a marca australiana entrar no Brasil. A diferenciação entre "expansão de marca com crescimento orgânico" e "fusões e aquisições", como dois modelos de expansão, seria uma característica dos novos planos da Natura. Tal esforço visaria "preservar" a marca para não descaracterizá-la com a ampliação dos negócios, que poderia associar à empresa produtos que não tenham tanta relação com seus "valores". Para o gerente de parcerias e alianças, "se é para ser pra todo mundo, ela acaba não sendo para ninguém porque o consumidor quer se identificar com a marca".

Um dos grandes desafios de todo este período de consolidação do crescimento foi como lidar com o governo. A partir de 2003, foi criada uma política de relações governamentais estruturada por dois pilares na busca por "transparência": 1) não contribuir com campanhas eleitorais e 2) fazer e defender abertamente uma política de lobby. Como explica Roberto Andrade:

"[A Natura fez doações de campanha] em quatro ou cinco eleições. Muito pouco. Eu acho que o ano em que mais se contribuiu foi alguma coisa em torno de... menos de duzentos mil reais para uns quatro ou cinco candidatos, enfim, de variadas cores. Então, já teve apoio para o José Serra, já teve apoio para o Alckmin, já teve apoio para a Marina Silva, quando a Marina era do PT, senadora do Acre, mas, enfim, poucas contribuições, todas declaradas. Mas, em 2004, a Natura virou uma companhia aberta e estava nesse processo de internacionalização. Então, como a gente vai fazer isso? Como a gente vai gerenciar essa questão em todos os países? Então, decidimos não fazer mais doações e, ao invés disso, investir, em cada eleição, aqui no Brasil, recursos para a conscientização da nossa rede. E o que a gente vem fazendo, desde então, é a campanha pelo voto responsável com o nosso exército de consultoras.

(...) [Para nós, o lobby é] o relacionamento da Natura, [cujo] fim principal é ter a Natura como interlocutora. Este é o fim do relacionamento da Natura com o governo e não ter todas as suas demandas atendidas porque é uma discussão que, se ela for boa mesmo, você vai ter que ceder, vai ter que abandonar aquela posição em algum momento porque aquela discussão foi aberta, foi franca e você estava disposto realmente, nas bases legais, transparentes e éticas, a ceder também. É uma negociação,

\footnotetext{
${ }^{26}$ De acordo com o que noticiou a Folha de São Paulo (20/12/2012), a Natura comprou o controle de “65\% da Emeis Holdings [empresa que opera a marca AESOP], fabricante australiana de cosméticos e produtos de beleza, por cerca de R\$ 148,7 milhões”. Disponível em http://www1.folha.uol.com.br/mercado/1204224-natura-compra-marca-australiana-de-cosmeticos.shtml.
} 
não uma imposição. A Natura não pode impor nada. Então, tendo isso como fim, ser um interlocutor primordial, sim [é efetivo], porque somos chamados, somos consultados, não precisamos mais ir lá. Sempre que tem alguma coisa relativa ao nosso setor ou às questões que a Natura historicamente defende, a Natura tem sido convidada. Então, sim, muito, temos sido muito bem sucedidos nessa caminhada."

Ao mesmo tempo em que a Natura prega "transparência" para lidar com lobby e abstenção de doações de campanhas eleitorais, em 2010 o copresidente da empresa Guilherme Leal foi candidato a vice-presidente na chapa de Marina Silva (então no PV) e um de seus grandes financiadores. A candidatura de Marina buscou trazer ao debate eleitoral questões relacionadas à "sustentabilidade" ambiental, a novas formas de participação e a novos valores de desenvolvimento e de consumo, adotando, desse modo, uma agenda próxima ao que Inglehart (1993) classificou de valores "pósmaterialistas”. É interessante notar que muitas destas questões assemelham-se ao que a Natura adota em seu discurso empresarial e publicitário a respeito da preservação do meio ambiente e da "responsabilidade socioambiental" que nortearia suas atividades na Amazônia, como mostrou Lima acima ao avaliar as possibilidades de negócio abertas pela "percepção" dos consumidores sobre a marca Natura e seus "valores". Guilherme Leal afastou-se temporariamente da empresa durante o período eleitoral, o que foi comunicado em carta enviada a todos os trabalhadores da Natura, bem como ao sindicato, afirmando, desse modo, fazer política "transparente". Nela, Leal dizia não pretender utilizar a influência e a dimensão da empresa da qual é sócio para realizar sua campanha. Esta seria realizada, segundo a carta, em caráter pessoal, já que Natura não teria candidato. Por fim, Leal afirmava que rechaçaria fazer propaganda de sua candidatura a seus empregados. Fazia-o... numa carta direcionada, como dito, a todos os trabalhadores da empresa.

Entre os "valores" que a Natura afirma defender, está a responsabilidade ambiental. Em Cajamar, inclusive, busca-se organizar uma "fábrica sustentável", através da educação de seus "colaboradores", do uso de energia solar, da reciclagem de água e de resíduos sólidos. Estas preocupações também se manifestam em metas da empresa. O relatório de 2012, por exemplo, aponta redução das emissões de gás carbônico em 7,4\% de 2008 a 2012 (abaixo da meta estipulada de 10\% para o período $)^{27}$. Nas relações governamentais da empresa, Roberto Andrade também apontou os temas ambientais como uma preocupação:

"[A Natura] tem o intuito de ser um interlocutor preferencial do governo e ajudar a construir uma agenda do país naquilo que a Natura acredita, quer, que faça

\footnotetext{
${ }^{27}$ Relatório Natura 2012. http://relatorio.natura.com.br/relatorio/node/7.
} 
sentido pro negócio, mas não exclusivamente. Só para te dar um exemplo: nós participamos da campanha "Desmatamento zero". O que isso tem a ver com cosmético? Não tem nada, mas tem tudo a ver no sentido em que é o país em que a gente vive, que a gente tem esse posicionamento. Então, a gente apoia”.

\title{
Opacidade e transparência: o lugar da "responsabilidade ambiental" como ativo econômico
}

\begin{abstract}
“O Brasil não é um país, por definição, onde se imaginaria encontrar um líder internacional de cosméticos. Isto historicamente não era suposto. (...) Só que nós inauguramos e tivemos, tenho a impressão, uma particular felicidade, a partir do ano 2000, de explorar a linguagem da potencialidade, da riqueza, da força da biodiversidade brasileira com a linha $\operatorname{Ekos}^{28}$. Isto abriu um potencial que está aí para ser melhor explorado e eu acredito que é esta a via de maior probabilidade, a via de maior potencial para as empresas brasileiras, mas em particular para a Natura porque a Natura é que saiu na frente. E saiu na frente de um jeito que, modéstia à parte, é como a Natura sabe fazer: realmente comprometida com as comunidades, com as comunidades na Amazônia, etc. Isto costumava ser e ainda é um impedimento operacional porque é muito complicado você atuar nessas comunidades. São culturas muito diversas e você tem que ter a disposição real de investir em regiões que são muito remotas, muito carentes. Fomos fazendo. Já temos 12 anos nesse tipo de convívio e acho que nesse aspecto nós estamos à frente de quase toda a concorrência".
\end{abstract}

Com estas palavras, Luiz Seabra, fundador e copresidente da Natura, mostra a relação entre o sucesso empresarial da companhia, sua expansão internacional e a "responsabilidade socioambiental". Muito além de um simples "valor" ou postura ética com relação ao meio ambiente ou às comunidades com que lida, a imagem criada pela Natura de empresa que incentiva o desenvolvimento sustentável e demonstra suas preocupações ambientais - inclusive, como destacou Roberto Andrade, em fóruns governamentais - tornou-se parte decisiva de sua marca e um atrativo para a compra de seus produtos e a expansão dos mercados.

Como se discutirá nos capítulos posteriores, o discurso empresarial da Natura organiza a produção e o trabalho levando em conta a demanda de "aderência à essência" 29 por parte de seus trabalhadores. Nesta "essência", a preocupação com os quesitos ambientais ocupa um lugar privilegiado, transparente, ainda que sejam opacos,

28 "Ekos" é uma linha de produtos da Natura baseada em matérias-primas típicas do Brasil (e da Amazônia em particular), extraídas por produtores locais em suas comunidades. De acordo com a apresentação que a empresa faz desta linha, trata-se de um "modelo de negócios sustentável de Ekos [que] leva em conta o desenvolvimento socioeconômico dos produtores rurais”. Disponível em http://naturaekos.com.br/.

${ }^{29}$ A questão da “Aderência à Essência” será abordada com mais detalhes no capítulo 3. 
de fato, seus efeitos para o grupo operário e mesmo para os que acessam as campanhas publicitárias da empresa. Trata-se de um verdadeiro ativo econômico. Um diálogo com Roberto Andrade e Pedro Lima é bastante ilustrativo deste jogo transparênciaopacidade, que parece sintetizar algumas das contradições do discurso empresarial da companhia.

[Roberto Andrade] "A gente agora está no processo de Avaliação de Aderência à Essência. É um processo grande, que é anual, que a gente faz, se nós mesmos... É uma autoavaliação, que a gente faz e pede feedbacks de gestores, de pessoas do time, de pares, etc.. Então, é uma avaliação extensa, eu diria, de você verificar se está expressando aqueles valores, este código de valores e se os seus colaboradores diretos, os seus pares, etc., também estão. Então, a gente passa por uma avaliação anual, por exemplo, para falar de pessoas, de aderência à essência. Os produtos, por exemplo, isso tem lá. O produto tem que entregar os atributos filosóficos da marca. Tem que estar aderente a isso. Tem que ter menos carbono e tem que gerar menos impacto e tem que ser melhor e tem que ser mais barato e tem que chegar melhor na consultora e tem que ser o que ela quer".

[Thiago Aguiar] É possível conciliar tais valores com as expectativas dos acionistas, a necessidade ampliar os lucros?

[Roberto] "Se a gente não fizer, a gente está na rua. Os acionistas mandam a gente pra fora. Basicamente isso. [Pausa longa e reflexão] É uma empresa um pouco diferente - e é isso que a torna tão bacana - é a visão de longo prazo. Se, no curto prazo, a gente for perder um pouco de qualquer coisa, de dinheiro, de share, sei lá, por falar a verdade, o compromisso com a verdade, a gente vai perder. E ninguém vai ser demitido por isso. Será demitido, vamos dizer assim, desligado, se você não tiver esse compromisso com a verdade".

Andrade, que, entre suas várias funções, atua como uma espécie de porta-voz dos controladores da empresa e de seus altos executivos, sabe que há algo de muito concreto e palpável para além da "essência" e dos "valores" cultivados pela Natura. Ao sinceramente dizer que se não for possível conciliar tais valores aos lucros eles estariam "na rua", o gerente chega ao limite do deslize. Por isso, pausa, reflete e recoloca a questão: sim, como em qualquer empresa, o que preside suas atividades é o lucro e a busca por sua ampliação, para além de qualquer outra preocupação; no entanto, retomando o controle de seu raciocínio, trata-se de uma empresa "diferente", cujo centro é a "verdade". Logo na sequência, entretanto, Pedro Lima, mais afeito às discussões práticas e instrumentais, arremata:

[Pedro Lima] "Primeiro, não é fácil fazer isso [conciliar "valores" e as expectativas de lucro dos acionistas]. Segundo, acho também que a Natura não pode dizer que sabe fazer isso perfeitamente. Esse é um processo de aprendizado para o resto da existência da Natura. Agora, o que acho que dá para falar é que a Natura é mais madura nesse aspecto do que $90 \%$ das empresas. Isso dá para falar com segurança. (...) Isso daí você consegue medir porque o resultado financeiro e o resultado socioambiental, primeiro, a Natura mede e, segundo, é muito maior que os competidores 
e não competidores. (...) Existe também essa crença aqui dentro, que faz parte de tudo isso, que é você unir esse esforço de preocupação socioambiental com o esforço de gerar valor para o acionista, que na verdade é um esforço de tratar bem todos os seus stakeholders [partes com que a empresa se relaciona, em linguagem de administração], que é difícil, gerar valor para todo mundo. Não é um esforço de 'eu perco aqui mas ganho ali'. É um esforço que gera... É uma atitude mental e corporativa que gera valor para todos, indistintamente. Por quê? Porque, em primeira instância, gera uma coerência de marca tão grande que as pessoas acabam admirando e, porque admiram, preferem comprar esse produto. E, porque admiram, aceitam pagar mais por esse produto e, portanto, valorizam mais essa empresa. Então, a lógica é que a gente faz porque gera valor - para todo mundo e inclusive para o acionista".

[Thiago Aguiar] Mas a empresa conseguiu transformar as preocupações socioambientais em um ativo econômico...

[Pedro] "É, com uma capitalização desse tamanho, é possível dizer que sim [Pedro e (também) Roberto riem bastante]. Com uma capitalização e uma margem desse tamanho é possível dizer que sim”.

\title{
Uma empresa onde nunca houve greve
}

\begin{abstract}
"Aqui em Cajamar, com certeza absoluta [nunca houve greve]. O que eu sei é que, pelo menos nos últimos 20 anos, nunca teve. Se teve, foi antes disso (...)

Hoje, nós temos uma relação com o colaborador que me permite não ser impactada por este olhar do sindicato. Então, toda vez que a gente comunica antes, que a gente explica o que foi, que a gente diz o que tem, que a gente abre este canal, o sindicato perde totalmente a força aqui dentro. À medida que eu não tenho este canal aberto, que eu não faço esta relação, o sindicato ganha força rapidamente. Esse foi o grande aprendizado (...)."
\end{abstract}

É desse modo que Susana Diniz descreve o que, para ela, é o sucesso da empresa em sua política com relação a conflitos trabalhistas e a relação com o Sindicato dos Químicos Unificados ${ }^{30}$, cuja comprovação seria o fato de não haver greve na empresa há pelo menos 20 anos. Trabalhadores antigos da empresa, como Antônio, diretor do sindicato, trabalhador da Natura desde 1991, cujo pai havia trabalhado na empresa e era amigo dos primeiros empregados de Luiz Seabra, confirmam a informação. Na planta de Cajamar nunca houve greve e não há notícia, retomando memórias e contatos de colegas que permitem chegar pelo menos até os anos 80 , de ter havido na empresa a paralisação organizada da produção por parte dos trabalhadores.

\footnotetext{
${ }^{30}$ O Sindicato dos Químicos de Osasco é uma regional do Sindicato dos Químicos Unificados de Campinas, Osasco, Vinhedo e regiões, uma interessante experiência de atuação conjunta de um sindicato em bases municipais distintas. O Sindicato dos Químicos Unificados surgiu a partir de plebiscito na base de quatro sindicatos em 2001, referendada em Congresso de Base da categoria em 2002, que decidiu pela atuação unificada.
} 
Isto não significa, no entanto, ausência de conflitos ou que a gerência não tome medidas visando à estabilidade de sua produção e a evitar que a atuação do sindicato estimule uma paralisação. Diniz explica que houve situações de tensão durante negociações salariais nas quais a empresa esteve à beira de uma greve. $\mathrm{O}$ aprendizado trazido nesta situação fez com que a área de Recursos Humanos desenvolvesse uma estratégia de relação com seus trabalhadores: antecipar-se ao sindicato.

"A gente já teve situações, vamos dizer assim, de crise em que a gente quase chegou a ter greve porque o sindicato atuava fortemente com questões que, enfim, nós não estávamos atentos. Então, ele acabou ocupando um espaço que a gente não previa. A gente estava numa negociação com os patronais. Eles não fechavam a negociação de dissídio e aí o sindicato voltou e falou assim [aos trabalhadores]: 'se vocês não fizerem greve, não vamos fechar'. Então, eles foram muito antes [falar com os trabalhadores]. A gente não estava dizendo para eles [os trabalhadores da empresa] o que estava acontecendo, qual era a política da Natura, o que a Natura estava fazendo. A gente perdeu esse ponto. A partir de agora, com esse aprendizado, a gente agora já faz tudo isto. A gente vai agora, sempre com uma comissão junto, e diz: 'o dissídio é tanto, as empresas querem dar tanto e nós vamos dar tanto'. E assim isso começa a caminhar. E a gente, assim mesmo, abre espaço. Então, eles vêm fazer assembleia, eles param o ônibus, eles falam".

Márcia, diretora do Sindicato dos Químicos, afirma que a Natura participa das negociações de dissídio anual, cuja data-base é $1^{\circ}$ de novembro, representada pelo sindicato patronal, o SIPATESP ${ }^{31}$, e não realiza negociações em separado com o sindicato. Segundo ela, os salários na empresa não diferem do piso da categoria: “Os salários seguem o piso da categoria. Em 2013, o piso era $\mathrm{R} \$ 1063,00$ e os salários pagos pela Natura [eram de] R $\$ 1080,00$, ou seja, uma diferença ínfima. Pagam o mesmo que as concorrentes".

A afirmação de Márcia parece ter eco na opinião que muitos dos trabalhadores entrevistados têm sobre seus salários. Em geral, eles afirmam que seu salário é igual ou inferior ao que se paga em outras empresas, mas esta diferença é compensada pelo valor da PLR. Questionada se está satisfeita com seu salário, Norma assim responde:

"Sim porque a gente tem uma boa PLR. O salário em si está igual ao de muitas empresas lá fora, mas o diferencial em si é uma boa PLR. Em termos de salário, tá igual o de outras empresas por aí, no mesmo patamar da Natura, no mesmo nível e, somando com a PLR, nosso salário eleva, né, fica em alta e aqui é legal pelo que eu falei. A gente tem a liberdade de ir ao RH, de passar algumas situações caso isso aconteceu, entendeu? (...) E o tempo todo eles estão treinando a gente. Eu falo: o tempo todo eles nos ensinam a nos defender, devido aos treinamentos que eles dão para a gente, a gente aprende a ter mais conhecimento, de até discutir de igual para igual porque eles são essa ferramenta para a gente."

\footnotetext{
${ }^{31}$ Sindicato das Indústrias de Perfumaria e Artigos de Toucador no Estado de São Paulo.
} 
O patamar salarial rebaixado é um elemento de descontentamento recorrente que se pode perceber ao insistir na questão durante as entrevistas, embora seja comum aparecer, como no relato de Norma, em meio ao elogio, igualmente presente em algumas vezes, à possibilidade de trabalho sem muito "controle" da supervisão como uma vantagem do trabalho na empresa, somada à PLR superior ao que se paga em empresas concorrentes do mesmo setor.

No que se refere à satisfação com o salário que recebe, Mariano apresenta uma opinião semelhante à de Norma.

"No aspecto salarial, poderia ser melhor porque, aqui na Natura, se você pegar a pesquisa de salário, quando a Natura faz a pesquisa de salário, ela pega tudo que $\mathrm{o}$ funcionário ganha $-13^{\circ}, 14^{\circ}$, a PLR e o salário. Daí soma tudo. Ah, num ano o funcionário tira $\mathrm{R} \$ 60$ mil. Aí eu vou pegar uma outra empresa. Vamos supor: a empresa B, lá, também o funcionário lá ganha $\mathrm{R} \$ 60$ mil por ano. Só que, nos $\mathrm{R} \$ 60 \mathrm{mil}$ dele lá, a PLR é menor. Só que na PLR não conta para o seu fundo de garantia. Então, várias outras coisas que o seu salário contaria - férias, $13^{\circ}$, tudo, tempo de casa - que na PLR não engloba. Aí é para o valor financeiro, uma fatura de um mês, né, mas o restante... Então, em relação à área, à atividade que a gente exerce, à importância que a gente tem na fábrica na área de manutenção, eu acho que poderia ser um pouco melhor. E tem muitos, tem gente da área de manutenção que está tendo a oportunidade de ir para outras empresas para poder ganhar quase $1 / 3$ a mais. Pelo que a gente já conhece de equipamento, a experiência que a gente tem e a mão-de-obra. Lá fora não encontra. [...] E tenho até proposta de sair para outras empresas também. Então, a Natura poderia reconhecer um pouco mais disso aí, como uma forma de segurar os profissionais que ela tem aqui dentro porque vai chegar uma hora que vai começar a faltar aqui. Aí vai ter que pagar mais querendo ou não".

Na opinião de alguns trabalhadores, como Mônica e Aurélia, embora de modo implícito esteja o reconhecimento de que os salários na empresa não sejam satisfatórios ou estejam no mesmo patamar de empresas concorrente, não transparece no entanto o descontentamento, ou ao menos frustração, presente nas declarações de Mariano e Norma.

"Então eu acho que é proporcional. [Em] outras empresas, um auxiliar de produção ganha mais, porém trabalha mais. Não que a gente não trabalhe, mais aqui tem muita máquina. Aqui o nosso trabalho não é um trabalho pesado, não é um trabalho braçal, então eu acho que uma coisa é proporcional à outra. Então, eu acho que salário é relativo. Se eu ganhasse $5 \mathrm{mil}$, eu ia gastar os $5 \mathrm{mil}$. Eu ganhando mil, vou gastar os mil. Acho que isto aí é relativo. Está proporcional ao seu serviço" (Entrevista com Mônica).

“Ah, foi feita a pesquisa no ano passado e está dentro do que a região pede. Todas as empresas fazem [pesquisa] para saber se estão pagando a mais ou a menos [A pesquisa salarial foi apresentada, segundo ela, pela empresa na comissão de PLR]. Tem a comissão, né? Sempre é escolhida uma pessoa de cada área, um representante, e ela participa das reuniões [...]. [A informação] é colocada em intranet, mural... Sempre a gente quer ganhar mais, né? Mas tem que estudar, né? Tem que estudar! (...) Eu acho que não tem esse negócio de sindicato pressionar. Eles [a empresa] sabem que têm que pagar. E a imagem deles lá fora? Tem esse 'merchan[dising]' também. Como ela 
fala: cuidar das relações, que é a 'essência'. Então, ela não vai deixar de pagar a gente." (Entrevista com Aurélia).

Para Mônica, os salários pagos pela empresa estariam condizentes ao trabalho que ela realiza. Talvez, ela também esteja expressando com sua resignação, através da afirmação sobre "proporcionalidade" entre o salário e suas tarefas, uma espécie de reconhecimento de sua posição social e da (pouca) valorização de suas qualificações na própria fábrica, tendo em vista que se trata de uma auxiliar de produção.

Aurélia, por sua vez, mostra-se não apenas resignada com o fato de que os salários pagos na empresa estejam sintonizados com a média do mercado (o que ela faz, note-se, levando em conta as informações sobre salários difundidas pela própria direção da Natura). Para ela, a forma de obter ganhos superiores no trabalho é exclusivamente individual: se alguém quer ganhar um salário superior, deve estudar! Coerente com sua visão da primazia do indivíduo na relação com a empresa onde trabalha e na responsabilidade pelo progresso de sua carreira profissional, Aurélia desvaloriza o sindicato e o papel da organização coletiva do grupo operário para reivindicar melhores condições de trabalho e salários.

Ela não demonstra insatisfação com o salário que recebe, mas sim com a posição que ocupa. Próxima de concluir a graduação em Farmácia, com 25 anos, ela espera ser promovida e, por essa via, melhorar sua condição de trabalho e remuneração. "Não [estou satisfeita] profissionalmente. Gostaria de estar em outra função, mas tudo tem seu tempo. Tudo tem sua hora, eu penso. Tudo tem sua hora, seu dia, não adianta querer acelerar o tempo", afirma.

A existência da comissão de negociação de PLR, feita entre empresa e representantes dos trabalhadores, e as informações fornecidas pela Natura sobre a situação salarial no mercado são, para Aurélia, a garantia de que os trabalhadores têm uma situação estável, na qual, se não ganham mais, tampouco recebem menos do que seus pares em outras empresas. A garantia de que tudo permanecerá assim - e da possibilidade de progredir individualmente caso haja esforço do trabalhador que estude e se qualifique - também reside no fato, para Aurélia, de que a Natura teria uma imagem publicitária a zelar. É como se o sindicato perdesse lugar e função. 
Susana Diniz mostra que, na realidade, os esforços da política de Recursos Humanos visam exatamente a isto: antecipar-se às iniciativas e posições do sindicato, esvaziando seu papel de interlocutor e representante do grupo operário organizado. Há uma tentativa de entrar no debate político e ideológico acessando diretamente o grupo operário na busca por dirimir resistências à ampliação da produtividade e à consecução das metas propostas pela empresa. Com isto, busca-se coordenar as expectativas dos trabalhadores com as metas empresariais, ao mesmo tempo em que se estimula o contato direto entre as posições da direção da empresa e o grupo operário a tal ponto que, para Diniz, constitui-se em "erro" ou "falha" se algum trabalhador busca o sindicato.

"Tem uma relação super próxima [entre empresa e sindicato], mas o que eu quero te dizer é que, assim, não tem um diálogo aberto. Porque eles têm um princípio claro. Isto é uma regra do sindicato. E foi isto que ele [um diretor do sindicato] me respondeu. Era uma época de PLR. Eu falei: nossa, isto é um bom caminho [a discussão sobre as metas na empresa] para a gente aprender junto. Vamos conversar. Mas, assim, eu topo fazer se nós fizermos juntos. Vamos sentar. Não quero fazer nada que depois a gente fica brigando por ter ou não ter, que visão tem ou não tem. Ele se enfezou comigo! Ele falou: 'aí você está querendo que eu volte 20 anos do que eu consegui andar como sindicato. O sindicato demorou 100 anos para ter voz ativa. A gente agora consegue ser o contraponto e você vai fazer isto. Não, nós somos, especificamente, contra! Estamos aqui para este papel. Então, não me chame para construir'. Ah, tá. Para mim, é frustrante. Quando eu estava em banco eu fiz algumas conversas com sindicatos e eu conseguia coisas muito boas - em São Paulo, no Rio nunca - e o sindicato vinha, trabalhava junto, dizia o que era melhor. Então, assim, eu tinha outra vertente. Aqui não rolou. Aqui não rola. (...) Eu sei que esse sindicato tem clareza de que ele é oposição. Sempre. Então, todas as vezes em que a gente vai falar alguma coisa, vem um texto completamente maluco, né? A gente tem que voltar e falar. O que a gente aprendeu é: a gente sempre dá a nossa versão antes. $E$ aí o sindicato diz o que ele quer. Então, coisas do tipo: ah, a gente tá pagando PLR a 90\%. Eles voltam e dizem assim: 'a empresa está abusando de vocês, está pagando $10 \%$ a menos. Vocês têm direito!'. Então, é assim: é resultado, é combinado, está acordado no sindicato. Mas eles sempre têm um olhar para o outro lado.

(...) Quando a gente lançou esta parte de TPM, o sindicato era super contra. Porque você, de uma certa maneira, imprime um grau de produtividade, de mais eficiência. E eles viviam botando nos jornaizinhos que a gente só pede mais. Um olhar totalmente avesso. E como isto representava de outra maneira, para as pessoas, desenvolvimento, crescimento e tal, [elas] nunca deram bola. Então isso passou despercebido (...). Eu acho o sindicato... Eu imagino que, no íntimo, eles possam dizer: 'ah, eu acho que é legal, essa empresa é boa e ela não entra nesse modelo escravista ou daquela história do começo do século como empresa'. Mas jamais vão dizer isto. E eles sempre têm um pontinho para pegar uma vírgula e dizer: 'nós vamos melhorar aqui e tal'. Porque é onde eles ganham dinheiro, é onde eles têm o processo, onde eles podem se colocar. A gente, internamente, percebe como um erro e como uma falha quando alguém vai direto no sindicato e não tem acesso à gente".

No entanto, não apenas no discurso empresarial transparece a busca pela antecipação ao sindicato - seja na discussão sobre dissídio, PLR ou outras questões 
relacionadas às condições de trabalho na empresa - com a consequente tentativa de esvaziamento do papel do sindicato como ator legítimo, representante do grupo operário, no cotidiano da empresa. Antecipação, nesse caso, não se refere apenas à busca por fazer chegarem as posições da empresa antes da visão do sindicato, dificultando a mobilização coletiva. A empresa também antecipa o próprio dissídio. Mariano, em sua resposta a questão sobre como vê as negociações salariais anuais, mostra os efeitos da política da empresa de antecipar o aumento salarial anual, antes das negociações entre sindicato patronal e o Sindicato dos Químicos, sobre a percepção que os trabalhadores têm da disposição da empresa em debater e atender reivindicações.

"A empresa discute com os funcionários [as negociações sobre dissídio]. A relação de PLR também, quando vai fazer eleição para a comissão de PLR é discutido com os funcionários, é aberto, vão os representantes da empresa, da área operacional e do sindicato. Isso é tratado em diálogo. E quando tem o dissídio também é tratado com o sindicato. E tem um negócio muito legal na Natura - e tem poucas empresas [em] que a gente vê isso aí - sempre que tem dissídio, o dissídio sai no mês de outubro ou novembro, dois ou três meses antes a Natura antecipa quase que $90 \%$ do dissídio que vai ser, entendeu? (...) A gente já chegou a pegar três meses antes [do dissídio], já tinha recebido o valor que acertou depois com o sindicato. Só acrescentou [depois] o restante que veio".

Recebendo meses antes da negociação uma parte do aumento que será posteriormente acordado, é provável que o esforço da empresa em diminuir o papel da mobilização e do sindicato para obter ganhos salariais tenha efeitos reais sobre os trabalhadores e que seu ímpeto de questionar um eventual percentual inferior a suas expectativas diminua consideravelmente. Daí que uma paralisação ou greve não seja vista como perspectiva a se adotar pela maioria dos trabalhadores. Ainda segundo Mariano:

\begin{abstract}
"Graças a deus a gente nunca precisou fazer greve aqui, de parar nada. A gente para assim, quando tem assembleia, para não criar confusão, o próprio pessoal da Natura orienta a gente: 'olha, vocês podem parar, vão lá ver o que eles querem falar'. [A gente] ouve de boa. Mas de parar, assim, fazer greve, isso nunca aconteceu aqui. Pelo contrário. Quando o sindicato se dispõe a fazer isso aí, a área operacional, ninguém se dispõe a falar 'ah, a gente vai parar' ou não vai porque a Natura vai penalizar. É aberto para a pessoa poder ir, você entendeu? Mas a pessoa não vai porque vê que não tem que fazer manifestação lá contra a empresa se a empresa está suprindo o que a gente tá esperando dela. Aqui não precisa [fazer greve]. Em 13 anos trabalhando aqui - 'ah, vamos parar a Natura' -, nunca teve uma situação assim e, dentro da área que a gente trabalha, funcionário falar 'ah, vamos fazer motim para poder parar'... Isso nunca aconteceu. E a gente conversa no dia-a-dia. Você vê agora, que estão tendo estas manifestações [de junho de 2013] que estão tendo aí por todo lugar, aqui todo mundo é tranquilo.
\end{abstract}

(...) O sindicato, aqui na Natura, para te dizer a verdade, chega sempre depois que o fogo apagou. Ou quando tem algum problema: o funcionário fica insatisfeito com 
alguma situação, vai lá e liga para o sindicato. Aí os caras vêm, fazem o jornalzinho e entregam aí na porta. O papel deles. Mas, em relação a pagamento, a contratação, esses negócios assim... O que é acordado, né, no acordo coletivo, a empresa sempre pega, né, sem problema, e já paga. O sindicato, aqui na área operacional, eles vêm bastante na Natura, mas, como eu posso dizer, colocar as situações que eles querem, são poucas as situações [em] que [o que] eles apresentam têm valia para a empresa e a empresa aprova. A maioria das coisas, mesmo quando tem PLR, quando eles vêm, a Natura já acertou o valor de PLR, a Natura só vai passar o valor para eles. Aí fica só a negociação entre eles. Quero mais, tal, aí fica o tempo deles. Mas o que a Natura coloca para eles lá é o que depois vem para cá”.

A Participação nos Lucros e Resultados, como se viu nas falas de Norma, Mônica, Aurélia, Mariano e de Susana Diniz, tem papel fundamental na política salarial da Natura, seja na atração de mão-de-obra, pagando salários na média do mercado, mas com PLR superior à concorrência, seja para antecipar-se ao sindicato e oferecer privilegiadamente sua visão através do formato de funcionamento da comissão de PLR, onde o sindicato tem assento, mas há um contato direto entre direção da empresa e representantes do grupo operário. Para Márcia, o funcionamento da comissão faz o papel do sindicato ser "quase formal".

“O programa que eles fazem é instituído no inicio do ano, quando eles fazem uma programação interna e posteriormente eles chamam o sindicato para formalizar e dar legalidade às metas. A participação do sindicato é quase formal e a comissão às vezes tem participação ativa, mas esbarra nos mesmo limites que nós, que é o estabelecimento das metas e tudo que se relaciona ao programa antes da negociação propriamente dita. Os valores são melhores comparados aos da convenção coletiva. Em 2013, [o valor da PLR] foi de R $\$ 760,00$ e o valor que poderia chegar na Natura seria mais ou menos $\mathrm{R} \$ 5000,00$, mas o acompanhamento do atingimento das metas fica todo com a empresa, que somente divulga em dezembro e aí quase não é possível fazer nada. Minha avaliação é que a PLR é o único atrativo para os trabalhadores na empresa, porém tem ficado pouco estimulante e muito difícil de atingir as metas estipuladas”.

Os efeitos da PLR e o papel das metas na intensificação do trabalho, no aumento da produtividade e, ao mesmo tempo, como forma de buscar o consentimento operário serão objeto de discussão mais aprofundada nos capítulos 3 , quando também se falará das lesões como um efeito da intensificação, e 5.

É possível dizer, pelo exposto até aqui, que a Natura habilidosamente consegue esvaziar o papel do sindicato e da mobilização na conquista de aumentos salariais e de melhorias para os trabalhadores ao mesmo tempo em que estimula, no grupo operário, a percepção de que há abertura e possibilidades de diálogo direto entre trabalhadores e a empresa. Tudo ocorre como se a empresa - e não a pressão dos trabalhadores e de suas organizações - concedesse anualmente o aumento antes inclusive das rodadas de 
negociação sindicais. Invisibilizando o papel do sindicato na conquista anual do dissídio para seu grupo de trabalhadores, através da antecipação parcial do aumento, a empresa tenta fazer com que o sindicato aparente reduzir-se quase a um "cartório", um agente que homologa o que a própria companhia decidiu e repassou aos trabalhadores meses antes da negociação. Certamente, para que até hoje a Natura tenha sido bem-sucedida em evitar mobilizações e greves, esta política salarial é decisiva.

A descrição de uma situação concreta pode demonstrar o que se afirma acima. No dia 11 de julho de 2013, na esteira das mobilizações que ocorriam em todo o país desde o mês anterior, houve um chamado unificado das centrais sindicais brasileiras por uma paralisação nacional (chamado de "Dia Nacional de Luta"). Em várias cidades do país, atividades produtivas foram paralisadas. O Sindicato dos Químicos Unificados planejava na data organizar uma assembleia e paralisação na fábrica da Natura, como parte da jornada de lutas daquele dia. Surpreendentemente, porém, a empresa, notando a movimentação que se organizava em frente à fábrica ainda de madrugada, pouco antes de se iniciar o turno da manhã, decidiu desviar todos os ônibus com os trabalhadores para o novo picking (distante da planta de Cajamar apenas 17 quilômetros na mesma rodovia Anhanguera) e logo após dispensar imediatamente os trabalhadores.

Flor, que atua na fábrica "Rio Amazonas", assim descreve os acontecimentos daquele dia:

"A Natura olha sempre o lado do colaborador. Já chegou a vez de eles [o sindicato] estarem aqui e eles passarem com o ônibus direto e levar o pessoal para o $\mathrm{NASP}^{32}$. Então, nós fomos para lá e lá receberam a ordem de dispensar. Foram aquelas épocas de manifestações que estavam tendo, né? Então, para não deixar o pessoal ficar parado ou, então, sem ter como ir embora, eles dispensaram. Nós ganhamos esse dia. Esta é uma das coisas que a Natura faz. Agora, o real motivo a gente não sabe, né? Teve o caso do AV [Armazém Vertical], que está amassado. Não sei se você reparou. Há quase um mês atrás, teve uma chuva aqui na região, uma chuva rápida, de vento, forte, que chegou a amassar um lado dele [do edifício]. Então, por isso, nesse dia não teve o primeiro turno. Foi num sábado. Eu vim num sábado. E, durante a semana, nós começamos a fazer um outro trajeto para ir embora por dentro porque eles queriam saber o que foi afetado, se tinha perigo, né? (...) Quer dizer: a Natura pensa na segurança de todo mundo sim! Nessa parte, tanto o que vai acontecer lá fora, como aqui dentro. Então, a Natura tem uma preocupação muito grande”.

A fala de Flor mostra que os trabalhadores, naquela circunstância, não apenas foram impedidos de tomar contato com o sindicato e decidir coletivamente em

\footnotetext{
${ }^{32}$ Novo centro administrativo e logístico da Natura, que recebeu estas atividades após a transferência deste setor (picking) da fábrica de Cajamar. Está localizado também na rodovia Anhanguera, no quilômetro 13, no município de São Paulo.
} 
assembleia se queriam ou não aderir ao movimento. Eles sequer puderam tomar contato com o que estava ocorrendo e saber a posição do sindicato. Na voz de Flor, pode-se encontrar a provável justificativa patronal para o ocorrido: a necessidade de garantir a segurança dos trabalhadores por conta dos transtornos no trânsito naquele dia e das passeatas previstas. Sua declaração mostra que esta decisão, claramente ferindo o direito à organização e atividade sindical, foi, por falta de informações, vista pelos trabalhadores como um ganho - "Nós ganhamos esse dia" - ao mesmo tempo em que foi identificada por eles com os procedimentos relativos à segurança do trabalho.

Com uma flecha, a empresa acertou dois alvos: mostrou uma postura benevolente e preocupada com a garantia da "segurança" dos trabalhadores ao mesmo tempo em que impediu que a mobilização proposta pelo sindicato pudesse ocorrer. Fortaleceu-se, assim, a imagem que procura apresentar a respeito da "transparência nas relações" com os trabalhadores. No entanto, o que ocorreu foi o exato oposto de transparência. Ao mesmo tempo, a deliberada confusão entre o bloqueio à participação na paralisação e a segurança serviu para fortalecer o discurso empresarial, reproduzido por Flor, de que a Natura "faz" uma série de coisas pensando na segurança dos trabalhadores "fora" da fábrica - ou seja, dificultando a atuação sindical - e "dentro", por conta das precauções, de resto um requisito legal e uma obrigação do empregador, com a segurança do trabalho.

Márcia, diretora do sindicato, avalia dessa forma a postura da empresa com relação à tentativa de mobilização promovida em 11 de julho de 2013:

"No dia nacional de luta o Sindicato dos Químicos Unificados foi para o portão da empresa para realizar uma assembleia com os trabalhadores. Eles desviaram os ônibus fretados da empresa e levaram os trabalhadores para a unidade de São Paulo, não permitindo assim o contato com o sindicato. Nos outros turnos, os trabalhadores foram dispensados. Penso que ali, na verdade, iniciou-se a postura dura intransigente da Natura naquele dia, estabelecendo que o sindicato não teria mais contato com os trabalhadores".

Apesar das tentativas de esvaziamento do papel do sindicato por parte da empresa, sua importância para os trabalhadores e a necessidade de que esteja presente no cotidiano da fábrica são valorizadas por muitos trabalhadores, ao mesmo tempo em que outros demonstram maior distanciamento ou, algumas vezes, até antipatia pelo sindicato, como mostram as falas a seguir: 
"[O sindicato] Tem importância. É uma forma de, quando acontecer algo que vai prejudicar a classe operacional, eles intervirem de alguma forma. Se tiver necessidade, sei lá" (Mariano).

"O sindicato não! O sindicato eu até falo: esse sindicato não me representa porque eles só fazem baderna. Não fazem nada. E até escrevem uns negócios no jornalzinho que não é verdade. (...) Então, poxa, as pessoas ficam reclamando, mas tem ouvidoria [da empresa]! Tem medo de pôr o seu nome? Não põe o nome! Simplesmente vai lá e reclama! Mas esse sindicato para mim não. Esse sindicato aí não vale nada. Esse sindicato aí... Os caras não sabem nem falar! Sabe? Eles colocam umas coisas no jornalzinho, mas quem falou isso daqui? Não é nada disso! Uma vez falaram até que a Natura estava se negando a dar água para os funcionários porque um bobão chegou lá e falou. Por que acabou a água na fábrica? Ué, porque acabou e outro não foi lá repor! Entendeu? Então, tem casos, assim, de o ônibus chegar de madrugada e eu mesma não desci do ônibus [para participar de uma assembleia]. Não sou obrigada! Aí, eles fizeram um monte de coisa! Quase me peguei com o cara lá. Não vou descer! Não sou obrigada! Desço se eu quiser! E as pessoas têm medo de falar, de fazer isso. Não é que eu seja, assim, que eu queira criar caso, mas eu não quero! Vou ficar lá no sereno, na chuva, no frio para ouvir abobrinha?! Sabe? Prefiro não! Então, assim: esse sindicato não me representa. Mas, assim, tudo que está errado na fábrica, eu vou e falo com o analista. Olha, está acontecendo isto, isto e isto" (Cida, auxiliar de operação, fábrica Rio Amazonas).

"[Na sua opinião, o sindicato é presente no cotidiano da empresa?] O nosso, dos Químicos, é. Eles vêm direto entregar jornais, notícias novas, vem falar quando é PLR, alguma coisa sobre horário. Eles sempre vêm comunicar a gente" (Mônica).

"Eles enchem um pouco o saco. Não sou muito fã de sindicato não porque eles só fazem barulho. Não vejo conseguir muita coisa, não, só fazem muito barulho. (...) Tumultos no portão. Eles fazem aí um tumulo. É até engraçado porque o sindicato quer que os colaboradores desçam do ônibus. (...) E aí eles querem obrigar a gente a participar, é muito chato, sabe? 5 horas da manhã! Eu não tô a fim!" (Dirce).

"Sim, ele [o sindicato] é útil porque têm muitas coisas que a gente quer [na negociação da PLR] e que a Natura não está de acordo e é aí onde o sindicato pesa. Então, a gente passa 'ah, a Natura não quer fazer, mas a fábrica, as pessoas em si, querem aquela meta'. Aí o sindicato intervém e faz aquela ação deles como jurídico, né? Eles [a empresa] até dificultam no início [a ação do sindicato], mas depois acabam cedendo porque se a maioria dos funcionários está insatisfeita com aquela atitude, com aquela meta, eles acabam cedendo, entendeu, pela maioria Participo, participo sim [das assembleias], como já participei das demais que já ocorreram. (...) Eles [a empresa] não dificultam. A gente participa. Até porque eu já tenho 14 anos de empresa e até hoje eu nunca vi 'ah, ele foi mandado embora, tomou advertência, por ter ficado lá na frente na assembleia'. Eu nunca vi, nunca presenciei isso" (Norma).

"Não, não desço [para as assembleias]. Uma que eles chegam de manhã. Você tá morrendo de sono, tá com fome, quer vir tomar café... Ah, não. Agora, quando eles vêm até o $\mathrm{NAN}^{33}$, que aí a gente pode vir, toma café e aí desce direto [para a reunião], aí sim. O pessoal vai em mais quantidade. Agora, de manhã é difícil. Falo: ah, não, não vou descer (...). Você tá cansado, você quer tomar um café, você quer despertar. Aí sim. $\mathrm{Eu}$ acho que se eles abrissem uma assembleia, que nem eles fazem [às vezes] a partir das 6 horas, tá todo mundo lá embaixo. Aí sim. Ou então se te pegam num dia de frio: você não vai ficar parado lá fora no frio. É difícil” (Flor).

\footnotetext{
${ }^{33}$ Flor refere-se ao Núcleo de Aprendizagem Natura, espaço onde são realizados cursos e palestras. O NAN fica na parte interna da planta. Ocorre, porém, que a maioria das assembleias e atividades organizadas pelo o sindicato é realizada em frente ao portão da fábrica, na parte externa. Dificilmente, por óbvio, o sindicato é autorizado, como afirmam alguns de seus diretores, a entrar na fábrica.
} 
A criação da planta de Cajamar, a modernização da Natura e sua consolidação como empresa global de capital nacional, como visto, trouxeram mudanças profundas na organização da produção e nas relações dos trabalhadores entre si, com seu trabalho e com as chefias. Pôde-se notar nas falas de algumas das trabalhadoras e trabalhadores que vivenciaram o período de transição que a introdução de formas flexíveis de produção foi acompanhada também por mudanças na sociabilidade no interior do grupo operário.

Ao mesmo tempo, na seção acima, pôde-se esmiuçar alguns elementos da forma como a Natura articula a relação com seus trabalhadores, o sindicato que os representa e sua forma de lidar com as negociações sobre salários e PLR. Se há, como visto, a tentativa de realizar um diálogo direto, apresentado pela direção da empresa como "transparente", com os trabalhadores, buscando antecipar-se ao sindicato e afastá-lo do cotidiano da fábrica, seria possível apontar para uma erosão dos valores associativos, da expectativa de garantir conquistas através da mobilização e da valorização do sindicato como locus de relacionamento e organização dos trabalhadores. De fato, vários destes elementos podem ser encontrados nas falas dos trabalhadores. Por outro lado, segue presente, para muitos, o reconhecimento da importância do sindicato na defesa dos interesses coletivos do grupo operário - a "classe operacional” nas palavras de Mariano.

O próximo capítulo pretende fazer uma digressão sobre a organização dos trabalhadores brasileiros à luz de alguns debates já clássicos da Sociologia do Trabalho em nosso país. A tentativa será de retomá-los para que se possa avaliar, sem pretender esgotar a questão, se e até que ponto o sindicalismo no pós-fordismo está fadado à decadência - na direção em que, por exemplo, argumenta Rodrigues (1999) - e em que medida é possível cogitar uma hipótese de revivificação do movimento sindical e das lutas dos trabalhadores no período pós-reestruturação produtiva no Brasil. 
Box 2: Algumas características do grupo operário da Natura a partir de dados ilustrativos - não representativos - dos trabalhadores associados ao Sindicato dos Químicos Unificados (regional Osasco) ${ }^{34}$

1) Distribuição sexual dos trabalhadores da Natura associados ao Sindicato dos Químicos Unificados

\begin{tabular}{|c|c|}
\hline \multicolumn{2}{|c|}{ Sexo } \\
\hline Masculino & Feminino \\
\hline 414 & 559 \\
\hline $43 \%$ & $57 \%$ \\
\hline
\end{tabular}

Total de sócios da amostra: 973

\section{2) Distribuição etária dos trabalhadores da Natura associados ao Sindicato dos Químicos Unificados}

\begin{tabular}{|r|r|r|r|}
\hline \multicolumn{4}{|c|}{ Faixas de idade } \\
\hline$\leq 27$ & $28-37$ & \multicolumn{1}{|c|}{$38-47$} & \multicolumn{1}{c|}{$\geq 48$} \\
\hline 147 & 483 & 263 & 80 \\
\hline $15,1 \%$ & $49,6 \%$ & $27,0 \%$ & $8,2 \%$ \\
\hline
\end{tabular}

Total de sócios da amostra: 973

\footnotetext{
34 Ao longo da pesquisa, houve diversas e infrutíferas tentativas de obter com a área de Recursos Humanos da Natura alguns dados sobre os trabalhadores da empresa, com vistas a sua melhor caracterização. Pretendia-se, com eles, ao menos conhecer sua distribuição sexual, etária, de escolaridade e de tempo de trabalho na empresa. Infelizmente, a companhia não os forneceu, ora alegando não poder disponibilizar dados que não estivessem contidos em seus relatórios anuais, ora afirmando que poderia atender a alguns dos pedidos em data futura, que, contudo, nunca se viabilizou.
}

Com a ausência de dados da empresa, tais informações foram solicitas ao Sindicato dos Químicos. Entretanto, o sindicato não possui informações sobre todos os trabalhadores da Natura. Constam em seu banco de dados algumas informações sobre seus associados, que são apresentadas no box 2. Optou-se por reproduzi-las aqui apenas a critério ilustrativo, já que as informações apresentadas não provêm de amostra representativa do grupo de trabalhadores da Natura e seria, portanto, impossível extrair conclusões bem acabadas e fundamentadas a respeito deles. Agradeço à gentileza do Sindicato dos Químicos Unificados (regional Osasco) por cedê-las e, em particular, a Nádia Gebara, assessora sindical, pela paciência em organizá-los e fornecê-los. A amostra é de 973 associados ao sindicato para os dados relativos a sexo e idade. Já no que se refere à escolaridade, a amostra é menor, de 393 associados, por não incluir recadastramento realizado pelo sindicato.

Os dados de rotatividade (turn-over) também foram demandados da empresa e tampouco foi possível obtê-los satisfatoriamente. No box, explica-se o porquê. Agradeço a Victor Gnecco Pagani, técnico do DIEESE, por fornecer a nota técnica de rotatividade do setor químico em 2012 do DIEESE e por alertar que provavelmente a taxa de turn-over informada por Susana Diniz mostre que a empresa utiliza metodologia diferente daquela adotada pelo DIEESE e pelo Ministério do Trabalho e Emprego (MTE) no cálculo do turn-over. 


\section{3) Escolaridade dos trabalhadores da Natura associados ao Sindicato dos Químicos Unificados}

\begin{tabular}{|c|r|r|l|l|r|}
\hline & \multicolumn{5}{|c|}{ Escolaridade associados 2013 } \\
\hline & EF* $^{*}$ & EM** & Superior & Não responderam & Total \\
\hline Absolutos & 2 & 294 & 51 & 46 & 393 \\
\hline$\%$ & 0,5 & 74,80 & 13,0 & 11,7 & 100,0 \\
\hline
\end{tabular}

Total de sócios da amostra: $393 /$ *EF - Ensino Fundamental/ **EM - Ensino Médio

\section{4) Dados de rotatividade (turn-over)}

Os dados de turn-over foram buscados com vistas a melhor compreender a intensidade da renovação do grupo de trabalhadores da empresa bem como para auxiliar na avaliação, especificamente, do caso de demissão de 33 trabalhadoras lesionadas na Natura. Ou seja, caso se obtivessem dados de turn-over precisos, seria possível discutir o impacto concreto do número de demitidas no conjunto de demissões imotivadas anual da empresa.

Susana Diniz, diretora de Recursos Humanos, em entrevista, afirmou que o turn-over na Natura era de 9\% para o ano de 2012. Esta informação, no entanto, não aparece no relatório anual da empresa. Os dados apurados pelo DIEESE (de acordo com sua nota técnica de rotatividade do setor químico), no mesmo ano de 2012, são de rotatividade global de 46,1\% e taxa de rotatividade descontada (desconsiderando os desligamentos que não se enquadram como demissão imotivada) de 33,5\% no setor de cosméticos, no qual a Natura é líder nacional de mercado.

Portanto, é altamente provável, pela discrepância entre os números da empresa e a média do setor cosmético, que a empresa utilize metodologia distinta da aplicada pelo DIEESE e pelo MTE. Para confirmar os números, utilizando a metodologia do DIEESE, seria preciso saber se houve aumento ou diminuição do número de trabalhadores ao final do período anual, o que é impossível, pois nos últimos relatórios a empresa informa apenas números aproximados de seus trabalhadores ("cerca de 7 mil"). Além disso, para o cálculo, seria preciso obter com o RH da Natura a média dos totais de empregados no início e no fim do ano, já que os dados da RAIS não permitem isolar e buscar os dados de uma empresa específica.

Como a Natura não disponibiliza dados que não estejam em seu relatório anual e as tentativas de obter alguns deles diretamente com o RH da empresa foram mal sucedidas, o cálculo do turn-over, de modo a confirmar a informação de Susana Diniz, não foi possível. Por isso, infelizmente, optou-se por não utilizar os dados de turn-over informados nas discussões realizadas na dissertação. 


\section{Capítulo 2 - Uma digressão sobre a organização dos trabalhadores brasileiros e o sindicalismo no pós-fordismo: há lugar para um novo "milagre"?}

Parece fundamental, para uma Sociologia do Trabalho no Brasil posterior à reestruturação produtiva, levar em conta nossas especificidades em termos de formação da classe operária, padrão de relações industriais assumido ao longo do tempo, organização sindical e o contingente ainda hoje expressivo de desempregados e trabalhadores no setor informal. Este capítulo é uma tentativa de realizar um pequeno balanço da discussão a respeito.

Há pouco mais de trinta anos, o sociólogo inglês John Humphrey publicou Fazendo o "milagre", obra de referência sobre o grupo operário do ABC paulista, que protagonizou as mais importantes mobilizações da história da classe trabalhadora brasileira, no triênio 1978 - 1980. Pode-se ler o "milagre" de que fala Humphrey de duas maneiras. Por um lado, evidentemente, a obra trata dos anos de grande crescimento econômico do Brasil durante a ditadura militar. Em especial, trata dos operários que "fizeram o milagre", os responsáveis por um período de crescimento da produção industrial e rápida expansão econômica do país. Por outro, porém, é possível entender o "milagre" como referência às enormes mobilizações operárias do $\mathrm{ABC}$, inesperadas para muitos observadores da época. Pela composição da classe operária, pelas dificuldades impostas por uma conjuntura adversa ou mesmo pelos entraves do padrão sindical corporativista brasileiro, vários analistas em debate no período anterior apontavam para a quase impossibilidade de desenvolvimento de um padrão de ação coletiva e reivindicatória dos trabalhadores brasileiros, particularmente daqueles que desde os anos 50 compuseram enormes contingentes de trabalhadores na incipiente indústria paulista.

O movimento de massas que enfrentou a superexploração imposta por poderosas multinacionais, a política salarial do governo militar e seu dispositivo repressivo poderiam ter sido vistos por muitos, naquele período, como "um raio em céu azul". No entanto, o acúmulo de contradições da sociedade brasileira cujo locus principal era a fábrica permitia compreender que se estava diante de um novo período para a classe trabalhadora do país. A virtude de Humphrey foi recuperar a produção como um local 
prioritário de investigação e buscar na totalidade as possibilidades de compreensão daquele fenômeno.

O que para muitos, hoje, pode parecer um conjunto de questões superadas em torno do surgimento do que se chamou "novo sindicalismo", num certo ponto de vista permite ao menos inspirar uma postura intelectual diante das mudanças paradigmáticas do trabalho no Brasil e no mundo e de suas consequências para a formação da identidade de classe e de um padrão de ação coletiva. Muito já se escreveu e debateu sobre a reestruturação produtiva e o que estava em questão com a mudança de um padrão fordista para um padrão pós-fordista, flexível, de organização da produção e do trabalho. Comum a muitos, está o diagnóstico de que tal processo impôs enormes dificuldades à organização dos trabalhadores. Seria o fim de movimentos reivindicatórios, ao menos como os conhecemos anteriormente, dos trabalhadores?

Essa discussão, ao menos, permite manter-se alerta sobre qualquer caracterização fatalista a respeito da inviabilidade da organização dos trabalhadores e de seus movimentos reivindicatórios a partir dessa transição. Aqui, levantam-se algumas questões e se apresentam alguns dos argumentos mobilizados por autores da Sociologia do Trabalho acerca das mudanças paradigmáticas do trabalho, dos desafios para o sindicalismo e para a ação coletiva dos trabalhadores. Além disso, serão discutidas as greves do ABC, através de Humphrey e Antunes, como um momento importante que pôs à prova uma série de diagnósticos até então majoritários sobre as possibilidades de mobilização dos trabalhadores brasileiros. Nosso interesse é refletir sobre se estaríamos de fato diante da modificação completa das possibilidades e da forma da ação coletiva dos trabalhadores, em que estaria em jogo por exemplo o "recuo do sindicalismo" (RODRIGUES, 1999), ou se ainda há espaço para a classe trabalhadora "fazer um novo milagre". Evidentemente, apesar da proposta algo provocativa, não há a pretensão de, nas poucas páginas seguintes, esgotar qualquer uma dessas discussões. O que se propõe simplesmente é colocar em questão alguns de seus aspectos.

\section{As mudanças na organização da produção e do trabalho: a passagem de um padrão fordista para um padrão pós-fordista}

Nas últimas décadas, a necessidade de recuperação dos lucros levou as empresas a buscar ampliar a produtividade do trabalho. O recrudescimento da competição internacional, o aumento do deslocamento de capital e o desenvolvimento de 
tecnologias de informação têm chamado a atenção de estudiosos de várias áreas do conhecimento. A Sociologia tem dedicado especial atenção às alterações nos padrões de relações industriais, na organização do trabalho e na gestão das empresas. Há um elemento fundamental para a compreensão de tal processo: o modo como se forjam novas identidades sociais operárias a partir dessas mudanças na produção e da crise de seus valores tradicionais.

As novas tendências de organização e de gestão do trabalho, desenvolvidas nos países centrais e, depois, difundidas para a periferia, aprofundaram a individualização da performance no trabalho e a pressão recebida agora também - e talvez sobretudo pelos pares. Além disso, assistiu-se à emergência de novas formas de remuneração e no tempo de trabalho.

Jacob Carlos Lima (2010) discute como a reestruturação produtiva acarretou, também, mudanças na percepção do trabalho e dos valores a ele vinculados. A aceitação do discurso da participação e uma forma de autonomia com forte viés individualista modificariam as possibilidades de que o caráter coletivo do trabalho fosse a base da identidade e da formulação de projetos globais a ele relacionados. A criação de uma "nova cultura do trabalho" seria, nesse sentido, a consequência do desmonte do trabalho coletivo. Com isso, perderam visibilidade projetos de transformação social e ganhou força um perfil de trabalhador "empreendedor de si mesmo", cuja responsabilidade é buscar sua formação permanente para manter o emprego. Tal responsabilização individual é parte de uma ressignificação do mundo do trabalho, em que a informalidade passa a ser valorizada. Evidentemente, como aponta Lima, o que está em jogo é uma disputa entre ideologias e contraideologias do capital, já que esta nova informalidade valorizada engloba desde consultores altamente remunerados em contratos individuais até trabalhadores precários excluídos de direitos trabalhistas. A relação entre as esferas pública e privada também se modifica, com o maior afastamento do Estado da regulação das relações capital-trabalho.

Argumentos semelhantes são apresentados por Stéphane Beaud e Michel Pialoux (2009) ao discutir as consequências das modificações na organização do trabalho para a classe operária de um ponto de vista sociológico. Eles partem do diagnóstico corrente de que, no mundo industrial, aumentou o desemprego e a concorrência entre operários. Ressaltam também que as grandes fábricas passaram a exigir escolaridade cada vez 
maior e um novo tipo de socialização para a produção. Esta é a "nova condição operária", cheia de contradições e conflitos, que opõem uma velha geração, com seus valores, rituais e totens, a uma nova geração que não reconhece o patrimônio simbólico da primeira.

Segundo os autores acima, a desestruturação do antigo grupo operário relacionase a um processo objetivo de mudanças na produção e a uma profunda desvalorização simbólica, cultural, política e subjetiva do grupo. O conflito geracional faz os filhos da classe operária rejeitarem a herança de seus pais. Em todos os lugares, repete-se a inadaptabilidade e o envelhecimento dos operários. A recusa a repetir a trajetória dos pais é estimulada pelo sistema escolar, cada vez mais consoante com as novas exigências da produção. Porém, a nova geração depara-se com a frustração de muitas vezes não conseguir romper com o passado.

No entanto, muitas das questões que motivaram antigas gerações operárias a constituir-se como um grupo - criação de vínculos, valores e instituições num processo de resistência coletiva - seguem presentes ou até se ampliaram num período de "forte degradação das condições de trabalho" (BEAUD e PIALOUX, 2009: 295) marcado por: intensidade do trabalho, acidentes, jornadas elevadas, conflitos com chefias, falta de democracia.

A caracterização da "empresa enxuta" (LIMA, 2010: 169), com uma nova cultura subjacente ao "capitalismo reticular" de que fala Lima, pode ser bem captada na descrição de Jean Pierre Durand. Para o sociólogo francês, em A refundação do trabalho no fluxo tensionado (2003), a introdução de tecnologias de informação e comunicação foi fundamental no processo de transformação da organização da produção e do trabalho. Os ganhos de produtividade, entretanto, não podem ser imputados somente à renovação tecnológica e à complexificação da produção. Pode-se falar numa "nova etapa de racionalização do trabalho" (DURAND, 2003: 140), marcada pelo uso da informática na gestão de materiais e homens, e de uma "nova combinatória produtiva" em que se destacam 1) a ampliação da circulação de informações; 2) a externalização das atividades da empresa para subcontratadas e fornecedores; 3) a externalização da mão-de-obra; 4) a avaliação por competência como forma de mobilização da força de trabalho; e 5) o "fluxo tensionado" (Idem, p. 142) orientando a produção através de uma "pilotagem pelo fim", em que o fluxo de informações ocorre de cima para baixo e o de matéria se dá de baixo para cima. O "fluxo tensionado", 
característico do toyotismo ou "modelo japonês", traz consequências de larga escala para a organização do trabalho. Introduz-se um elemento de naturalização: é o fluxo o responsável pelo ritmo e pelas condições de trabalho e não a chefia ou um superior identificável.

Pode-se dizer que mesmo no cenário das fábricas reestruturadas, pós-fordistas, continua havendo conflitos que opõem uma classe a outra classe (operários e patrões) em termos estruturais. Porém, a nova geração não foi socializada no espírito comunitário e associativo da geração de seus pais, que são os operários fordistas típicos. Há, então, uma espécie de paradoxo nesse período. Na discussão a respeito do pósfordismo, como se nota, também não há lugar para generalizações. No “capitalismo reticular" convivem formas distintas de organização da produção e do trabalho. É fundamental ter em mente esta questão ao se discutir as consequências de tais mudanças para a organização dos trabalhadores e para o sindicalismo neste período.

\section{As greves metalúrgicas de 1978, 1979 e 1980 como momento fundamental da formação da identidade coletiva da classe trabalhadora brasileira}

No Brasil, a tradição de sociologia industrial tem raízes que remontam aos anos 50, em São Paulo, com Juarez Brandão Lopes, além de Leôncio Martins Rodrigues nos anos 60. O trabalho desses autores pode ser visto como uma primeira tentativa de sistematizar o estudo sociológico das relações de trabalho. Muitas questões que aparecem como pertinentes apenas ao atual cenário de reestruturação produtiva e pósfordismo, na verdade, podem estar presentes desde aquela época.

A formação (tardia) da classe operária brasileira não seguiu os padrões clássicos de formação e desenvolvimento do capitalismo europeu. Juarez Brandão Lopes, em Sociedade Industrial no Brasil (1964), mostrou como contingentes migratórios rurais, crescidos em comunidades onde domina a racionalidade tradicional, compuseram a classe operária paulista. Muitas vezes pretendendo retornar à pequena propriedade rural - aqui a pressão da expropriação dos meios de produção não se fez presente como no caso típico inglês -, os trabalhadores industriais semiqualificados ou não qualificados não teriam desenvolvido laços de solidariedade ou padrões de ação coletiva. A possibilidade de retorno ao campo ou o desejo de abrir negócio próprio sempre significaram dificuldade para a estabilização da classe operária e responderam por grande parte do alto turnover visível nas primeiras décadas de industrialização. 
Desse modo, para Lopes, não se criou uma solidariedade de classe entre esse incipiente operariado paulista. Orientado para o retorno ao campo, o migrante nordestino não se comporta como os trabalhadores dos países de desenvolvimento capitalista mais consolidado. Por isso, com a ausência de consciência de classe, para Brandão, não seria possível esperar do grupo operário paulista padrões de ação coletiva, mas, antes, uma relação individualizada com o trabalho fabril, vista, por exemplo, na maneira como lida com a legislação trabalhista. Os críticos de Juarez Brandão Lopes apontam para a necessidade superar uma visão de modernização que, ao orientar-se pelos casos típicos europeus, atesta a impossibilidade da criação de padrões coletivos de ação operária.

$\mathrm{O}$ movimento dos operários metalúrgicos do $\mathrm{ABC}$ em fins dos anos 70 colocou em xeque muitos destes argumentos. Afinal, boa parte daqueles que fizeram greves e lotaram assembleias multitudinárias eram migrantes nordestinos em sua primeira experiência como trabalhadores industriais. A criação de práticas renovadas de sindicalismo e o impulso à formação da CUT e do PT são a demonstração da formação de uma forte identidade de classe desse grupo operário.

John Humphrey debate com esta tradição de análise da classe trabalhadora brasileira. Questionando Leôncio Martins Rodrigues, para quem os operários por ele entrevistados nos anos 60 viam o sindicato como uma entidade assistencial, o sociólogo inglês afirma que este diagnóstico apresentava muito mais o estado do sindicalismo no período do que uma atitude geral dos operários para com o sindicalismo, derivada "das características estruturais gerais da classe operária (teorias de migração, valores rurais, etc.)" (HUMPHREY, 1982: 144). Numa chave distinta, também se contrapõe a Maria Hermínia Tavares de Almeida (1975), para quem o sindicalismo de São Bernardo demonstraria as contradições entre uma legislação generalizadora da classe trabalhadora (a CLT) e a diversificação da economia brasileira, que traria a heterogeneidade estrutural no interior da classe. Os metalúrgicos do ABC, parte de um "setor moderno" da economia, desse modo, passariam a apresentar demandas específicas de sua condição na produção e poderiam estar construindo, em germe, um modelo de "sindicalismo de negócios".

Questionando se o grupo metalúrgico de São Bernardo era uma espécie de aristocracia operária que começava a apresentar exigências diferenciadas do conjunto da classe trabalhadora, Humphrey afirma ser fundamental analisar a "questão da unidade e da diversidade da classe operária". Adotando uma perspectiva totalizadora, ele aborda 
as reivindicações anteriores e as apresentadas nas greves de 1978 - 1980 para chegar à conclusão de que o centro de suas reivindicações estava no combate à política salarial do governo militar, que levava ao "arrocho" e à superexploração. Estes eram os pilares da política econômica do governo militar e submetiam não apenas este grupo operário, mas o conjunto da classe trabalhadora brasileira.

A diretoria do Sindicato dos Metalúrgicos de São Bernardo tinha uma ligação profunda com a base que representava. Atuantes nas fábricas, os diretores tinham plena consciência do que inquietava os trabalhadores metalúrgicos e foram, ao longo dos anos, ganhando maior autoridade. A reivindicação de recomposição salarial respondia a um desejo de milhares de trabalhadores submetidos à decomposição salarial, ao trabalho em condições muito duras e numa conjuntura política bastante adversa. Aos poucos, a postura pró-empresarial do governo militar também foi sendo revelada. A greve de 1978 foi fruto de alguns anos de experiência do grupo operário com negociações de dissídio que não levavam em conta os sentimentos dos trabalhadores, de sonegação de informações sobre a inflação e a corrosão salarial por parte do governo e do enorme descontentamento com as chefias e sua política de alta rotatividade de trabalhadores para pressionar os salários para baixo. Os trabalhadores metalúrgicos e a direção de seu sindicato foram percebendo que a greve era a única saída. Misto de espontaneidade com esta experiência, a greve demonstrou a relação entre as demandas econômicas e o conflito político.

Nos anos seguintes, esta relação revelou-se ainda mais. A FIESP e o governo passam a adotar uma política de linha dura nas negociações e pressão sobre os dirigentes sindicais. Por isso, as reivindicações de maior autonomia do sindicato, organização por local de trabalho, contratação coletiva e negociação direta com os patrões revelavam não um desejo de autonomia por parte de um grupo operário privilegiado frente à classe, senão a necessidade de maior liberdade de organização dos trabalhadores num contexto de repressão e autoritarismo. Nesse sentido, Humphrey discorda do argumento de Almeida sobre o possível desenvolvimento de uma fissura entre sindicatos "fortes", dos trabalhadores em setores "modernos" da economia, e setores "fracos". É possível dizer que a negociação direta conquistada pelos metalúrgicos de São Bernardo não apenas não prejudicou trabalhadores de outros setores, como os favoreceu ao pressionar a política salarial do governo militar que submetida a todos. Além disso, as fundações da CUT e do PT, no bojo de tal processo, 
demonstram a vocação mais ampla do projeto político defendido à época pelo "novo sindicalismo".

Ricardo Antunes, em A rebeldia do trabalho (1988), apresenta muitos argumentos semelhantes aos de Humphrey na caracterização das greves metalúrgicas do ABC. Vale sublinhar, em especial, a hipótese central de seu trabalho, que afirma ter sido "o eixo das Greves de Maio [de 1978] (...) contra a superexploração do trabalho, contra o arrocho salarial" (ANTUNES, 1988: 27). Este era seu "elemento fundante". A centralidade da reivindicação salarial, no entanto, não significa uma prática de sindicalismo "apolítico". Muito pelo contrário. Apesar das avaliações distintas de cada uma das três greves, para Antunes simplesmente o fato de que elas tenham existido tinha um enorme significado político. O enfrentamento à política salarial do governo, a manutenção de greves - mesmo quando declaradas ilegais, quando começa a haver demissões ou quando a diretoria do sindicato é presa - era uma demonstração poderosa da disposição da classe trabalhadora em enfrentar também na arena política a ditadura militar. Um exemplo simbólico de tal disposição deu-se quando, na greve de 1979, o governo interveio no sindicato e os trabalhadores realizaram uma tomada simbólica da instituição. De conjunto, o movimento operário de 1978 - 1980 "tratava-se, portanto, concretamente de um movimento político de classe, desencadeado por um de seus segmentos, o operariado metalúrgico" (ANTUNES, 1988: 86).

Alguns importantes matizes, no entanto, diferenciam Antunes da perspectiva de Humphrey. Para o primeiro, as greves foram marcadas por um forte grau de espontaneísmo. Os trabalhadores metalúrgicos, não suportando mais a política de arrocho salarial do governo, em 1978, promoveram greves por fábrica e a "irrupção da espontaneidade operária". O segundo, por outro lado, como discutido anteriormente, destaca o papel da direção do sindicato em todo o processo. Não apenas nos três anos das históricas greves, como nos anos anteriores, em cada batalha por que passou o sindicato - a luta pela negociação em separado da Federação, a busca pela organização no local de trabalho, as campanhas pela reposição salarial em 1977 e 1978 - houve, para Humphrey um acúmulo de experiência da direção do sindicato e do grupo operário, chamado à mobilização em cada um desses momentos. Se houve um forte componente espontâneo, não se pode negar, contudo, o importante papel que coube àquela geração de sindicalistas.

\footnotetext{
${ }^{35}$ Em itálico no original.
} 
Para Antunes, tal caráter espontâneo desdobrou-se numa falta de direção política das greves. Ainda que não negue a preparação da direção para as greves de 1979 e 1980 - o chamado de Lula à trégua e à negociação em 1979 após vislumbrar um cenário difícil para a luta e a criação do comando de greve no ano seguinte, por exemplo -, por outro lado teria faltado um esforço de análise "científica e estratégica" para acumular mais do que um avanço de "consciência espontânea". A direção do sindicato teria sido refém do espontaneísmo do movimento e muitas vezes teria seguido sua disposição ao invés de antecipar-se a ele para propor os passos seguintes.

Humphrey, por sua vez, não enfatiza tal dimensão. Numa perspectiva bastante convincente, trata das especificidades da indústria automobilística e da força potencial daquele coletivo de trabalhadores e mostra como a direção do sindicato não apenas estava muito relacionada à base como foi hábil em utilizar as brechas do sistema sindical corporativista. A discussão a respeito da ação coletiva dos trabalhadores e do sindicalismo num contexto de mudanças no padrão de organização da produção e do trabalho no Brasil, aliás, precisa levar em conta um balanço das reflexões acerca do sindicalismo brasileiro.

\section{Algumas palavras sobre o sindicalismo corporativo brasileiro}

A permanência do modelo sindical corporativo brasileiro chamou a atenção de inúmeros pesquisadores do trabalho no Brasil. Leôncio Martins Rodrigues (1990) trata das origens desta modalidade de sindicato no Brasil e tenta explicar os motivos de sua longevidade. Para ele, a via corporativa brasileira explica-se pela amálgama de interesses em jogo no contexto da Revolução de 30 e da modernização econômica nos anos seguintes. Uma oligarquia decadente, do ponto de vista econômico, mas com fortes posições no aparato burocrático criou tal modelo para garantir sua hegemonia ao mesmo tempo em que, desse modo, a fraca e incipiente burguesia nacional foi adaptando-se a tal sistema e relacionando-se com o governo num momento em que se criavam políticas protecionistas e de substituição de importações. Aos trabalhadores, em especial ao menos qualificados, foram garantidas proteções inéditas. Com o tempo, tal sistema passou a ser objeto de interesses, criando e expandindo uma burocracia sindical, da qual muitos dirigentes sindicais são parte. Os empregadores, por sua vez, beneficiaram-se do fato de que tal estrutura tenha sido responsável pelo amortecimento dos conflitos.

Eli Diniz e Renato Boschi (1991) demonstram que a criação do sistema corporativo esteve relacionada com a modificação do eixo da economia de uma base 
agrária para uma base industrial. Sem uma clara hegemonia burguesa, o corporativismo foi o canal pelo qual novos grupos puderam ser incorporados e expressar seus interesses. "O Brasil ingressa na modernidade industrial pela via corporativa" (DINIZ e BOSCHI, 1991: 18), afirmam. Tratou-se, desse modo, da criação de uma forma específica de articulação público-privado, que incluiu de modo distinto empresários e trabalhadores, mas, apesar disso, permitiu aos últimos acesso a uma arena pública, até então inédita, pela qual poderiam buscar direitos e benefícios. Tal articulação públicoprivado explicaria a longevidade deste sistema.

Rodrigues não desconhece o fato de que a liderança do "novo sindicalismo" surgiu de dentro da estrutura corporativista. Entretanto, para ele, o mesmo sistema que permitiu seu surgimento também foi utilizado para controlar o movimento através da intervenção em 1980. Com uma perspectiva marxista estruturalista, Armando Boito Jr. (1991) afirma ser impossível a "conversão do sindicato oficial, de instrumento de controle dos trabalhadores, em seu contrário. O sindicato de Estado é, sempre, e ao contrário do que se passa com outros tipos de sindicalismo, uma instituição que amortece o conflito de classes" (BOITO JR., 1991: 16). A filiação voluntária, a falta de autonomia (posteriormente revertida na Constituição de 1988), a mediação pela Justiça do Trabalho, o imposto sindical e a unicidade sindical seriam todos problemas derivados de uma questão central, que faz com que o sindicato no Brasil seja irremediavelmente atrelado ao Estado: a investidura sindical, ou seja, o reconhecimento pelo Estado de que um sindicato é o representante legítimo e legal - e único - de uma dada categoria de trabalhadores numa determinada região. A estrutura sindical brasileira torna o sindicato dependente de um ramo da burocracia do Estado e tal dependência, para Boito Jr., faz com que o movimento de trabalhadores no Brasil, apesar das várias demonstrações de vigor reivindicativo ao longo da história, padeça de uma debilidade organizativa crônica, que impede seu avanço e leva ao amortecimento dos conflitos de classe. Boito Jr. trata das possibilidades de variação nos efeitos do controle por parte do Estado com muita reticência, já que a "estrutura sindical e seus efeitos são dotados de uma elasticidade relativa (...) [cujos] limites nunca rompem a barreira que é imposta pela própria lógica da estrutura: se é o Estado que outorga a representação sindical, é ele que, obrigatoriamente, regula-a" (Idem: 40).

No entanto, se os limites dentro dos quais os sindicalistas podem agir, dada a correlação de forças entre as classes, são tão estreitos e acabam por submeter totalmente a organização dos trabalhadores ao Estado, dificilmente o movimento metalúrgico do 
$\mathrm{ABC}$ de fins dos anos 70 teria alcançado tal vulto. Humphrey insiste no fato de que a direção metalúrgica pôde manobrar com tais limites, por um certo período de tempo, num contexto em que as contradições na fábrica eram imensas e o impulso à luta aumentava dia a dia no interior do grupo operário. Desse modo, apesar de algumas tergiversações da direção a respeito de seu posicionamento com relação à estrutura sindical, a unicidade, por exemplo, foi útil naquele contexto para evitar a divisão da categoria por conta das disputas pela representação legítima. Mesmo a oposição uniu-se à direção do sindicato naquela luta. Quando, ao final, ocorreu a intervenção, a tomada simbólica do sindicato demonstrou que, a despeito da real debilidade organizativa que a estrutura sindical traz à organização dos trabalhadores, esteve em jogo, ao menos para aquele grupo operário em luta, uma clara noção sobre a quem pertencia, afinal, o sindicato. Ele pertencia aos operários.

Tal discussão revela-se útil por vários motivos. A estrutura sindical corporativa, em que pese ter havido mudanças nas últimas décadas, permanece. Num contexto de transformações na organização da produção e do trabalho, novas gerações de trabalhadores precisarão lidar com tal estrutura para organizar-se. Fica a questão de até onde a debilidade organizativa apontada por Boito Jr. poderá ser superada. Há, na atualidade, direções sindicais comprometidas com a mobilização dos trabalhadores? Em que medida a estrutura sindical dificulta-lhe os movimentos? Poderá surgir, numa conjuntura de polarização como a vivida pelos operários metalúrgicos do $\mathrm{ABC}$, uma vanguarda operária como aquela?

Por outro lado, os desafios para o movimento operário estão principalmente na estrutura sindical brasileira ou há algo mais? Que questões a reestruturação produtiva e as mudanças paradigmáticas do trabalho e da produção trouxeram? Parece-nos ser preciso, então, refletir a respeito delas e recolocar o debate sobre as relações entre economia e política para tratar do atual cenário.

\section{Como forma de concluir}

Uma fotografia revela apenas parte da realidade. Reproduz um aspecto. Enfatiza o estático. Muito já foi discutido a respeito da reorganização da produção e do trabalho e da introdução de novas tecnologias, num processo de mudança para um "capitalismo flexível" ou "pós-fordista". A generalização das consequências desse processo para a organização política dos trabalhadores e para o movimento sindical é, no entanto, problemática. Richard Sennet (1999) traça um panorama de tais consequências para a 
vida dos trabalhadores. O caráter pessoal foi completamente modificado numa sociedade que passou a valorizar o provisório e a adaptabilidade a novas situações. A reestruturação das rotinas e a lógica do risco permanente dificultam a formação de valores estáveis e submete os trabalhadores a uma espécie de "deriva" em que o trabalho perde a possibilidade de oferecer uma orientação de longo prazo e a formulação de um projeto daí decorrente.

Se, por um lado, tal diagnóstico do capitalismo contemporâneo parece bastante fiel aos processos de reestruturação a que se assistiu nas últimas três décadas, por outro é necessário questionar se seria válido para todos os trabalhadores. Trata-se de um grande desafio compreender as desigualdades, sem evidentemente perder o marco geral da discussão, ao se ter em vista que o pós-fordismo complexificou a produção: a terceirização, a externalização das atividades, as novas formas de contratação, de remuneração e de uso do tempo introduzem novas variáveis que tornam qualquer generalização difícil.

Para Rodrigues (1999), há dois grandes grupos de fatores, socioeconômicos e político-institucionais, que estariam minando as bases do sindicalismo. Sem debatê-los a fundo, parece útil, em especial, tratar das conclusões a que chega o autor. A tese que apresenta afirma: "as características gerais da sociedade pós-industrial abrem pouco espaço para a organização sindical, embora a extensão desse espaço possa ser diferente quando se avaliam sociedades nacionais específicas" (RODRIGUES, 1999: 301). Por isso, para ele, pode-se falar em "recuo do sindicalismo à medida que avança a desindustrialização" (Idem). Sem ignorar as especificidades nacionais e as variações no ritmo da mudança, para Rodrigues há um processo internacional em que o sindicalismo, tal como se conheceu - misto de instituição e movimento que expressa "algum componente de oposição aos que estão no comando" (Idem, 297) -, entra em decadência. Não seria seu fim, mas certamente, com o passar do tempo, causado pelos fatores antes discutidos, seus dias de pujança e glória teriam ficado para trás.

Armando Boito Jr. (2003) critica as hipóteses de Rodrigues e a caracterização de declínio do sindicalismo. Para ele, pode-se falar num refluxo internacional do sindicalismo, mas que se desenvolve de modo desigual e combinado. Com isso, Boito Jr. pretende levar em conta a totalidade da economia capitalista mundial. O refluxo seria maior nas economias centrais - e, mesmo ali, já haveria tendências de recuperação ${ }^{36}$.

\footnotetext{
${ }^{36}$ Pode-se mencionar, por exemplo, como forma de ilustração, a greve geral ibérica ocorrida em 14 de novembro de 2012, quando sindicatos de Portugal e Espanha, a partir de chamado da CGTP-IN
} 
Não levar em consideração o crescimento do sindicalismo em novas áreas produtivas, especialmente na Ásia, onde antes era muito fraco, seria um desvio eurocêntrico. Mesmo no Brasil, tal caráter desigual e combinado se manifestaria na medida em que há recuo do sindicalismo se se compara ao cenário dos anos 80 , mas há mais atividade sindical se a referência são os anos 50 e 60. Boito Jr. critica, em especial, a abordagem acerca de duas questões teóricas daqueles que argumentam em favor do declínio do sindicalismo: em primeiro lugar, tais observadores não levariam em conta corretamente as mudanças na composição da classe trabalhadora e nem compreenderiam suas reais consequências. Seria possível existir com o tempo, afirma Boito Jr., a organização de um forte movimento sindical do recente proletariado de serviços. Subestimar tal possibilidade seria o mesmo que fizeram os que se surpreenderam com o movimento dos ferroviários, trabalhadores do setor de serviços, no século $\mathrm{XX}$, em vários países. A crítica mais importante levantada por Boito Jr, a nosso ver, no entanto, trata da relação entre a política e a economia. Para ele,

"O erro teórico do raciocínio que estamos criticando consiste em analisar a classe operária e o sindicalismo separadamente do processo político nacional e internacional. Toda classe social deve ser analisada em sua relação com as demais classes sociais, nunca isoladamente" (BOITO JR., 2003: 331).

Seria, então, um erro economicista considerar a forma específica de que se reveste a fragmentação do trabalho nessa etapa do capitalismo como a única existente. Sempre houve, argumenta Boito Jr., heterogeneidade e fragmentação socioeconômica.

Por isso, parece-nos correto argumentar no sentido da recuperação da dimensão da política, já que muito deste debate se processou numa conjuntura de forte ofensiva ideológica neoliberal que, diga-se, parece estar em franco processo de mudança. Os anos recentes têm trazido demonstrações de que talvez os trabalhadores e suas organizações e sindicatos possam voltar a ter protagonismo num futuro próximo: as recentes notícias de numerosas greves e organização sindical em vários setores na China e outros países asiáticos; a crise econômica internacional e as respostas massivas que já se processam, inclusive por movimentos de trabalhadores, em países europeus como Grécia, Portugal e Espanha; as mobilizações no norte da África e no Oriente Médio que derrubaram regimes autocráticos; e, last but not least, as recentes jornadas de junho de 2013 no Brasil, um movimento de massas que a princípio questionou o aumento das

portuguesa e posterior adesão de sindicatos e centrais dos dois países, organizaram um dia de greve geral na Península como forma de combater as políticas de austeridade impostas pela Troika (FMI, Banco Central Europeu e Comissão Europeia) e adotadas pelos governos dos dois países no contexto da crise econômica europeia. 
tarifas de transporte em diversas cidades e se ampliou, exigindo a conquista de novos direitos e abrindo espaço para um dia de paralisação nacional dos trabalhadores, em 11 de julho, fato inédito em muitos anos ${ }^{37}$.

A leitura de Humphrey deixa duas questões interessantes sobre as possibilidades de ação coletiva dos trabalhadores. O sociólogo inglês encerra sua obra com uma reflexão sobre a relação entre a economia e a política. Como marxista, Humphrey tenta ao longo da obra demonstrar as relações dialéticas entre ambas, ou seja, como o que se passa no âmbito da produção e da economia determina a política e como, por sua vez, a política também pode num sentido determinar a situação na produção.

"No início dos anos 80, as perspectivas para os trabalhadores da indústria automobilística são incertas. Dependem mais do desenvolvimento geral da vida política no Brasil do que da situação das fábricas. No entanto, a análise dos desenvolvimentos políticos no Brasil precisa ser fundamentada num estudo concreto da existência material das forças em luta. A luta no nível da produção permanece um aspecto vital, mas pouco estudado da experiência da classe operária no Brasil” (HUMPHREY, 1982: 244)

Por tudo o que se disse anteriormente, tratar o desenvolvimento do movimento sindical brasileiro do surgimento do "novo sindicalismo" aos dias atuais à luz dessa instigante reflexão pode ser interessante. Se é verdade que muitas das tendências de reorganização da produção e do trabalho incidiram em cheio no país e trouxeram dificuldades para a organização dos trabalhadores e o movimento sindical, é duvidoso afirmar que tal situação permanecerá a mesma no médio prazo. Os acontecimentos de fins dos anos 70, numa conjuntura política dificílima para a organização sindical e quando ainda se falava no "milagre econômico", podem ser uma importante referência para a discussão das perspectivas para o sindicalismo brasileiro.

Há algo mais: no debate com Almeida, Humphrey demonstra que o sindicalismo de São Bernardo não caminhava na direção de um modelo de "sindicalismo de negócios", de tipo estadunidense. Um dos principais argumentos para rechaçar tal possibilidade, entretanto, era que naquela conjuntura política o estabelecimento de um sindicalismo que negocia permanentemente com a empresa e é por ela reconhecido "teria significado um rompimento total com o sistema sindical estabelecido e com as formas de relações industriais instituídas pelo Estado, (...) bem como sérios problemas

\footnotetext{
${ }^{37}$ A falta de dados consolidados sobre o ano de 2014 neste momento impede afirmar categoricamente, mas parece evidente que o número de greves no Brasil, crescente nos últimos anos, deve encontrar no período 2013-2014, na esteira das jornadas de junho, seu maior patamar, bem como de horas paradas por atividade de greve, em duas décadas, apontando para um possível reaquecimento da atividade sindical no país.
} 
políticos" (HUMPHREY, 1982: 177). Ou seja, tal possibilidade estava descarta do ponto de vista de trabalhadores e de empresários naquele contexto.

Hoje, no entanto, com um olhar retrospectivo, não seria possível questionar a respeito do desenvolvimento, em alguns setores econômicos particularmente, de um sindicalismo que "aceita a lógica do sistema capitalista monopolista (..) [e é] integrado a ele" (Idem, 232)? No ramo automobilístico, passadas décadas dos históricos conflitos do $\mathrm{ABC}$, as negociações em torno da flexibilização e o tipo de prática sindical que desenvolvem hoje as entidades outrora pioneiras do "novo sindicalismo" parecem ser indícios disso. Em grande medida, saíram de cena os grandes enfrentamentos e mobilizações. Se esta for a referência, em comparação com o que houve anteriormente, podem parecer bastante razoáveis os argumentos em favor do recuo do sindicalismo e de sua nova localização no século XXI.

Por outro lado, a complexificação da produção trouxe uma série de novos personagens e de novas questões. Há muitos setores taylorizados convivendo com fábricas bastante "modernas", que adotam preceitos pós-fordistas. A terceirização e a precarização do trabalho são uma realidade muito mais presente, no conjunto da classe trabalhadora, em relação aos novos empregos "pós-industriais" em que a dimensão valorizada dos quesitos de autonomia, participação e flexibilidade estão presentes. Talvez já possam ser encontrados indícios, como as grandes greves no setor da construção civil a que assistiu o país nos últimos anos, da renovação e do crescimento do sindicalismo no país, envolvendo também novas categorias profissionais, que começam a deparar-se com o desafio da organização coletiva como resposta aos problemas estruturais que a produção capitalista segue impondo-lhes. Muito se disse a respeito de um momento de desenvolvimento econômico do país vivenciado nos últimos anos. Este terá uma correspondência social com a formação de uma nova classe operária brasileira? Evidentemente, este é um processo incipiente e em processo. Por ora, e apenas por ora, questionar se haverá "um novo milagre", nos dois sentidos insinuados na obra de Humphrey ainda está no campo das especulações. 


\section{Capítulo 3 - Nos limites do "comprometimento": a demissão de trabalhadoras lesionadas e a desestruturação do antigo grupo operário na Natura}

Novas tecnologias produtivas, regime de metas, internacionalização e best practices de um lado; de outro, intensificação da produção e doenças do trabalho. Em novembro de 2010, 33 trabalhadoras, a maioria das quais lesionadas em processo de readaptação ${ }^{38}$, mulheres e que estavam há bastante tempo na empresa, são demitidas num caso que parece bastante representativo do que está em jogo nas empresas flexíveis.

"Ah, foi humilhante. Porque, assim, a gente chegou e eles entravam um de cada vez. Estavam ele [o gerente] e uma mulher que a gente nunca viu. Eles ficavam sentados, ajeitando o cabelo, e sorrindo. 'Se você quiser assinar, você assina. Se não quiser, é seu direito não assinar"” (Juliana, em entrevista conjunta com Darci).

“Eu falei: eu não vou assinar. 'Então tá [disse o gerente]. Ela assina por vocês'. E o pior de tudo: um funcionário que está há 10, 15 anos na empresa, tem direito a fazer o [exame] demissional. Nenhuma fez demissional. Nenhuma menina. Ninguém fez o exame. E simplesmente mandaram a gente 'se virar'. 'Vão para o posto, vão procurar, vão atrás dos seus direitos"” (Darci, em entrevista conjunta com Juliana).

"Eu virei para o médico [da empresa] e falei assim: o senhor, sendo dono de uma empresa, aceitaria eu, com uma cirurgia na mão e outra no cotovelo, como sua funcionária? Uma pessoa que não tem força para trabalhar com agilidade? Aceitaria? Porque ele falou assim: 'Você pode usar as suas qualidades para trabalhar em outro lugar'. Eu falei bem assim para ele: bem, a única qualidade que eu ainda tenho é a minha língua, que não tem tendinite, (...) não vou desistir. Vou procurar meus direitos sim. (...) Aí eu falei pra ele assim: você daria um emprego para alguém como eu trabalhar? Alguém doente? 'Não'. Não. Eu falei: o senhor tá vendo? O que eu vou fazer agora? (...) Empresa nenhuma hoje pega alguém com tendinite para trabalhar porque as empresas, hoje, fazem um exame admissional da ponta do fio até a ponta do dedão. Então, ninguém vai querer trabalhar com a gente mais. Ninguém” (Juliana, em entrevista conjunta com Darci).

Era desta forma, com um misto de indignação e tristeza, que várias das trabalhadoras se manifestavam durante as entrevistas ou nas reuniões com o sindicato para discutir sua situação. Boa parte das trabalhadoras demitidas estava “em reabilitação profissional em função de quadro de LER/DORT (Lesão por Esforço Repetitivo/ Doenças Osteomoleculares Relacionadas ao Trabalho) adquirido na própria empresa"39.

\footnotetext{
${ }^{38}$ De acordo com levantamento do Sindicato dos Químicos de Osasco, ao menos 22 delas possuíam algum tipo de lesão adquirida durante o tempo em que trabalhavam na empresa. As mulheres compõem a maioria do grupo, razão pela qual se opta por usar o substantivo feminino.

${ }^{39}$ Conforme carta-denúncia do Sindicato dos Químicos Unificados à Câmara dos Deputados.
} 
A maioria dessas trabalhadoras tem "entre 35 e 44 anos, eram funcionárias da Natura há pelo menos oito anos" $" 40$ e tinham passado por período de afastamento do trabalho motivado pelo quadro de LER. Muitas delas, além disso, haviam sido operadas ou esperavam por cirurgias já agendadas àquele momento. Trata-se de uma força de trabalho "velha", "desajustada" e doente, que vai sendo substituída.

Quando de seu retorno ao trabalho, foram instaladas numa linha especial de readaptação na fábrica "Rio São Francisco". "Quem arrumou essa linha foi o INSS junto com a Natura, que decidiram que quem estivesse em reabilitação tinha que ficar ali. Não podia sair dali", narra Juliana. Nessa linha especial, eram-lhes destinadas atividades de "retrabalho", ou seja, de consertar defeitos em produtos oriundos de outras linhas.

"A nossa célula não tinha metas. A gente tinha que atender prioridade: 'Olha, meninas, parem tudo o que vocês têm que fazer pra fazer um favor pra gente? A gente precisa entregar $\mathrm{x}$ até o final do dia. Você pode fazer? (...) A gente se acabava, mas a gente fazia" (Entrevista com Darci).

No entanto, em seu período de retorno à empresa após o afastamento por lesão, passaram não apenas a trabalhar numa linha diferente como a vivenciar uma experiência de exclusão, na prática, das atividades regulares da empresa e mesmo a ser discriminadas pela gerência e até por alguns de seus colegas de trabalho. O tema das metas e da PLR estaria, segundo narram, no centro dessa questão. Fisicamente incapazes de perseguir as metas estipuladas pela empresa, passaram a ser vistas com desconfiança pelos próprios colegas, uma vez que seu desempenho, a seus olhos, poderia afetar as metas coletivas. Por outro lado, tampouco tinham condições de buscar metas individuais, razão pela qual muitas vezes se viram privadas dos 'prêmios' distribuídos pela empresa quando se alcançam metas desse tipo.

Pairava sobre sua célula uma espécie de "estigma": ausência de metas, separação clara das outras células, inespecificidade, cuja síntese é a marca de “faz tudo". É como se a célula não tivesse uma qualificação que a legitimasse perante as outras, o que mostra como a qualificação é uma noção completamente relacional e social. Beaud e Pialoux (2009) abordam tal aspecto ao discutir a relação entre os antigos Operários Especializados (OEs) da fábrica da Peugeot-Sochaux e o grande número de

\footnotetext{
${ }^{40}$ Boletim do Sindicato dos Químicos Unificados de Campinas, Osasco, Vinhedo e Regiões - Especial Natura, abril de 2011.
} 
trabalhadores temporários que afluiu à oficina nos anos 80. Os temporários, mais jovens, buscavam uma oportunidade para ser contratados em definitivo e eram, nesse sentido, concorrentes dos mais velhos. Mais disponíveis às exigências da chefia e menos propensos à ação sindical que marcava a "cultura de oficina" do período anterior, os temporários - e posteriormente os jovens contratados formados pelos novos currículos oferecidos pelo sistema escolar francês - revelavam aos OEs antigos seu envelhecimento biológico e social, colocando em questão seus saberes e qualificações, num processo, estimulado pela Peugeot, de desvalorização simbólica da geração operária antiga, destinado a facilitar a implantação das medidas de flexibilização num tipo de conflito que opôs, nas palavras de Pialoux (2011), o "velho operário e a nova fábrica".

Nas reuniões entre sindicato e trabalhadoras demitidas, várias situações ilustrativas a respeito eram narradas. Algumas linhas ganhavam uma hora adicional para café, cestas de produtos ou até mesmo churrasco num fim de semana por terem alcançado determinada meta incidental proposta pela empresa.

"Estimulam muito, muito, porque um quer ser melhor do que o outro. Pessoas doentes se matando de trabalhar para ganhar. Eles estimulam as pessoas para ganhar churrasco, prêmios, café... Você, por uma coisinha de nada, não ganha e fica olhando os outros terem 1 hora de café.” (Entrevista com Juliana).

As trabalhadoras na linha de reabilitação, contudo, nunca podiam recebê-las. Não apenas a remuneração anual da PLR, mas também estes benefícios são muito valorizados pelo conjunto de trabalhadoras.

"As pessoas da gerência, eles empurram as pessoas para ser um melhor do que o outro. E como a gente era uma célula pequena, a gente não trabalhava com produção, só com retrabalho, então era onde a gente servia de chacota para as pessoas. (...) Um quer ser melhor do que o outro. Pessoas doentes, se matando de trabalhar para ganhar churrasco, café. (...) Ganhavam uma pausa de uma hora para café. A gente, que estava em reabilitação, não ganhava não.” (Juliana, em reunião das trabalhadoras demitidas).

A concorrência no interior do grupo operário é apontada como uma das principais consequências da introdução das células pela literatura a respeito da flexibilização da produção. Jean Pierre Durand (2003), por exemplo, fala a respeito do "fluxo tensionado", que traz grandes consequências para a organização do trabalho. O trabalho em grupo, por sua vez, para o autor, implicaria na publicização e socialização 
do savoir-faire, requisito para a exigência de polivalência. $\mathrm{O}$ paradoxo do aumento do fluxo informacional é que, do ponto de vista gerencial, a autonomia e a eficiência são ampliadas, mas, por outro lado, o indivíduo é pressionado por seus pares no grupo - um constrangimento naturalizado, já que cabe a todos atender às exigências impessoais "do fluxo" sob pena de perder seus rendimentos individualmente. O segredo é a mobilização do trabalhador coletivo para manter a tensão do fluxo ao mesmo tempo em que, para isso, se exige e se recompensa a lealdade do trabalhador individual. Amarildo Silveira ${ }^{41}$, dirigente sindical, destaca este como um dos principais aspectos da PLR: "um trabalhador controla o outro. (...) O cara fica com medo de faltar, trabalha doente com o atestado no bolso porque 'se você faltar, você vai lascar a gente na linha de produção!'. Você tem noção da pressão psicológica?".

Norma, trabalhadora da fábrica "Rio da Prata", entrou na empresa em 1999 e viveu a transição da antiga fábrica de Itapecerica para Cajamar. Ela também desenvolveu LER no trabalho. Após cirurgia, tratamento e afastamento do trabalho, ela retornou a suas funções na produção. Ao falar sobre o trabalho na célula e a relação no interior do grupo operário e com os superiores, ela mostra os efeitos do controle pelos pares no trabalho sob o "fluxo tensionado", de que fala Durand, ao mesmo tempo em que deixa claro como o interesse pelos ganhos da PLR - e, portanto, a necessidade de cumprir as metas empresariais - condiciona estas relações.

‘Um cobra o outro - 'Fulano, vamos lá! Está precisando de ajuda?' - a gente tem que estar passando o tempo todo estes objetivos porque, no final, a gente sabe que tem a meta para atingir e, no final, a gente tem a nossa PLR em jogo. Então, é bom para o nosso crescimento pessoal, mas também a gente pensa no futuro, na frente. Se eu não conseguir fazer o melhor de mim, eu não vou ganhar, mas também a culpa foi minha. Eu não posso só culpar só a empresa porque uma parte dessa culpa foi minha, se eu não corri atrás, se eu não estou nem aí e eu não atingi a meta, então a culpa foi minha. Então, é um retorno, uma troca: você dá e eles te dão. Se você não dá, sinto muito, entendeu? Então, a gente corre atrás pensando nisso sim. Não vou ser hipócrita de dizer que a gente não pensa porque a gente pensa sim. Porque a gente sabe que vai vir um bom dinheiro para a gente. Tanto que é assim: se a gente atinge 90\% [das metas], a gente recebe $90 \%$ do piso total delas. Então elas são proporcionais. Se a gente atinge $100 \%$, é $100 \%$ que a gente recebe. Então, a gente sempre busca os $100 \%$.

(...) $\mathrm{O}$ gestor tem uma visão que a gente não tem. Ele já sabe de uma visão de mercado, lá fora, de vendas, que a gente não tem. A gente sabe que está vendendo aquele produto $\mathrm{x}$ por mês, $\mathrm{x}$ por semana, mas a visão atual quem está tendo o tempo todo é o gestor, então a gente um pouco obedece ele sim. [...] A gente entende e respeita. Faz o que tem que fazer, que é quebrar o setup, parar a linha aqui para completar a linha lá. Porque, de uma certa forma, não é a minha meta só. É a meta da

\footnotetext{
${ }^{41}$ Os nomes dos dirigentes sindicais, bem como de trabalhadores e pessoal da direção da empresa, como já enfatizado outras vezes ao longo da dissertação, foram substituídos por nomes fictícios.
} 
fábrica. Então, não adianta eu pensar na minha linha só e não pensar na linha do colega porque, no final, é o resultado em conjunto que vale".

De modo eloquente, Norma mostra como o trabalho coletivo é acionado na célula através, no entanto, do "comprometimento" do trabalhador individual. É possível pôr em questão o próprio discurso empresarial a respeito da "polivalência" ou da "autonomia" ${ }^{42}$ do trabalhador ao ver, pelas palavras de Norma, como as posições e demandas da chefia seguem fortemente presentes. Talvez, a aceitação e mesmo concordância com as posições da gerência ("O gestor tem uma visão que a gente não tem") seja facilitada pela preocupação crescente do grupo de trabalhadores em coesionar seus esforços e integrá-los às metas empresariais por conta dos requisitos da PLR.

Dirce, trabalhadora da fábrica "Rio da Prata", também fala da relação entre o interesse pelo ganho máximo da PLR e o estímulo que o grupo tem, na célula, para dar conta das metas propostas pela empresa:

[Dirce] "Com certeza [a PLR] é um incentivo, um estímulo. As pessoas ficam muito satisfeitas quando conseguem atingir [as metas]... Mas eles correm atrás para receber, especialmente quando vai chegando o final [do período]. Às vezes, as pessoas não se envolvem tanto, mas quando vai chegando mais perto eles se empenham mais". pessoas?

[Thiago Aguiar] Se as metas não são alcançadas, qual a reação das

[Dirce] "Nossa, você não tem noção! Querem pendurar no lustre! Eles ficam bem insatisfeitos. Bolso, né, meu filho. Mexe em qualquer coisa, mas não mexe na parte sensível do colaborador".

Mas não se trata apenas de ganho econômico, como mostram as falas das trabalhadoras lesionadas demitidas. Aspectos simbólicos e de status parecem ter papel importante na cobrança permanente dos trabalhadores sobre o trabalho dos colegas, como revela Norma ao falar sobre alguns dos conflitos vividos em seu dia-a-dia:

\section{[Thiago Aguiar] Existem conflitos entre os colegas?}

[Norma] "Têm [conflitos]. A gente tem. Como em todas as indústrias, todos os trabalhos. Conflitos pessoais, a famosa picuinha. A gente tem, mas tenta lidar de uma forma, assim, da catraca pra dentro é profissional. Se daqui para fora, você não quer almoçar com seu colega, isso aí é pessoal seu. Mas eles deixam isso aí bem claro de que a gente tem que ter a postura de profissional. [...] Tem [picuinha], coisinhas

\footnotetext{
${ }^{42}$ Vistos por exemplo, no capítulo 1, na descrição da diretora de RH, Susana Diniz, do TPM e da introdução na empresa de formas flexíveis de produção.
} 
desagradáveis, 'ah, minha máquina é melhor que a sua!', 'a minha está produzindo melhor que a sua', 'a sua está dando retrabalho, a minha não tá', quanto pessoal, né?”

[Thiago Aguiar] Mas por que há discussões deste tipo?

[Norma] "Porque é motivo de orgulho! [...] Então, se alguém cometeu uma falha na qualidade, por exemplo, errou em alguma coisa. Então, dá a impressão de que você é desatento, passou despercebido. Onde você falhou? A pergunta é: onde você falhou? Por que aconteceu isto na sua linha?" questionam?

[Thiago Aguiar] Então, se algum colega não está trabalhando bem, vocês o

"Sim, a gente faz o feedback negativo. Olha, fulano, você está despercebido aqui, ali. Lógico, de uma forma educada. Nada de informalidade porque sou o operador, sou o gestor, de impor... Mas de conversar, saber o que está acontecendo com aquele colega. Porque se não é o perfil dele, algo está acontecendo para ele estar naquele nível. Então a gente tenta buscar aquele nível daquele profissional que a gente conhecia porque às vezes é um momento que aquela pessoa está passando, que está acontecendo isto. Então, a gente conversa, uma, duas vezes. Se for necessário, a gente faz um feedback escrito, entendeu? Aí, se for uma coisa mais grave, a gente passa para o gestor. Mas, até aí, a gente tenta resolver entre nós, entre equipes e sempre dá certo”.

Desse modo, Norma mostra que há uma espécie de “orgulho" por ver a célula da qual participa produzindo em quantidades satisfatórias, sem ocorrência de problemas em máquinas ou defeitos nos produtos que possam ocasionar queixas dos colegas e superiores e mesmo a desvalorização, por meio de "picuinha", de seu trabalho pelos pares. Ou seja, nas atividades cotidianas dos trabalhadores, há algo além das preocupações exclusivamente relativas ao ganho econômico, ainda que este condicione aquelas. A imbricação entre a busca pelo ganho econômico maior por parte dos trabalhadores e a satisfação simbólica que encontram (o "orgulho" de fazer o trabalho bem feito, de receber um "feedback" positivo e de não ser alvo de "picuinha" dos colegas) permite encontrar paralelos interessantes com o que Burawoy (1989) descreveu a respeito dos "jogos" de bater a meta. Estes possibilitam aos trabalhadores obter uma satisfação residual no trabalho para além de seus ganhos materiais ao mesmo tempo em que pode ser instrumentalizado pela gerência capitalista de modo a "obscurecer e assegurar” (BURAWOY, 1985) a mais-valia. A tentativa de desenvolver estes nexos através do caso da Natura será realizada no capítulo 5, onde são sintetizadas as conclusões desta dissertação.

Quando foram anunciadas as demissões, a empresa alegou ${ }^{43}$ que "o desligamento de 33 colaboradores de suas fábricas de Cajamar [foi ocasionado] por falta

\footnotetext{
${ }^{43}$ Ao jornal Brasil de Fato (20/12/2010), disponível em http://www.brasildefato.com.br/node/5330.
} 
de comprometimento". Imediatamente, o sindicato buscou pressionar a empresa pela reincorporação das trabalhadoras. Uma comissão de trabalhadoras chegou a ir a Brasília discutir com parlamentares ${ }^{44}$ e entregar uma carta, preparada pela equipe jurídica e médica do sindicato, que mostrava tratar-se de demissão de trabalhadoras com doenças do trabalho. Meses depois, já em 2011, os diretores do sindicato, sem acreditar numa saída jurídica para o caso, propunham mobilização para fazer frente à questão. "A ideia é reverter as demissões, (...) mas nós não vamos conseguir nada da empresa, nada, que não venha da mobilização e da luta. Conversar, discutir com a empresa, essa história de 'bem estar bem', de preocupação com os colaboradores, é tudo fachada" (Rubinho, diretor do Sindicato dos Químicos de Osasco).

Não houve, contudo, uma mobilização que conseguisse reintegrá-las. A demissão de um conjunto numeroso de trabalhadoras, a maioria das quais há muitos anos na empresa e com lesões ocasionadas pelo trabalho, não deveria causar indignação e mover os trabalhadores? Várias questões - as dificuldades conjunturais do sindicalismo, a eficiência da empresa para fazer com que o caso não tomasse proporções maiores, o receio dos trabalhadores de envolver-se numa mobilização, etc. - poderiam ser discutidas a respeito. Há, entretanto, um aspecto que seria interessante abordar: até que ponto as trabalhadoras demitidas, isoladas numa linha especial e acusadas de terem pouco "comprometimento" com a empresa, eram vistas, naquele momento, como iguais pelos colegas? Em que medida a falta de solidariedade e de mobilização, por parte dos colegas, para reverter as demissões, têm relação com o tipo de conflito e de "picuinha" narrado por Norma? Os relatos das trabalhadoras demitidas permitem avaliar estas questões:

“Aquela vez que a gente foi pra Brasília, a gente serviu de piada lá dentro (...) Todo mundo lá: 'você tem algum problema, vai pra Brasília!' Viramos motivo de piada, principalmente a nossa foto que saiu no jornal, eles colocam na parede, tirando um barato. Eu não ligo pra isso não, eu não ligo, mas eu acho o seguinte: eles estão no mesmo barco que a gente ou até pior". (Roberta, em reunião das trabalhadoras demitidas)

"As pessoas começaram a fazer piada, falaram que a gente era encostada, que não fazia nada, que era um bando de pessoas inúteis (...). Pegam o jornalzinho que a gente saiu, o jornal do sindicato, e colam no banheiro. Os próprios líderes também. Os líderes tratam a gente como piada (...) São os analistas, lá a gente tem vários analistas, controle de qualidade, segurança”. (Juliana, em reunião das trabalhadoras demitidas)

\footnotetext{
${ }^{44} \mathrm{O}$ que motivou, inclusive, pronunciamento do Deputado Federal Ivan Valente (PSOL-SP) na tribuna da Câmara em 14/12/2010.
} 
Questionada sobre o caso de demissões, o relato de Norma (uma trabalhadora que também já viveu caso de lesão!) parece mostrar que as trabalhadoras lesionadas demitidas já não eram mais vistas como iguais em sua capacidade de trabalhar, mas também de relacionar-se com os colegas e ser parte do grupo operário. A situação é apontada por Norma como uma questão individual de cada uma das demitidas com o RH:

\section{[Thiago Aguiar] Houve um caso de demissão de trabalhadoras lesionadas. Você soube deste caso? O que você achou do que ocorreu?}

[Norma] "Sim [riso desconfortável]. Olha, tem dois lados dessa questão. (...) São aquelas duas versões. Você é um funcionário, independente de você ser reabilitado ou não, você volta e você não faz nada mesmo sem ser reabilitado, a empresa prefere te mandar embora e pagar uma demissão se for o caso, entendeu? E têm outros casos que é porque as pessoas pedem [demissão]. Então, tipo assim, pediu em janeiro. Eles vão analisar o caso da demissão. Não é duma hora para outra que eles vão mandar."

[Thiago Aguiar] Então, você acha que foi por conta disso?

[Norma] "É. Dos dois lados. Uma parte - pelo que eu fiquei sabendo porque eu estava afastada quando elas foram mandadas embora - tinha pedido. Mas quando mandou elas não queriam mais. Só que aí não passa para o gestor e ninguém tem bola de cristal para saber o que você quer se você não fala. (...) Então acontece o ato da demissão. Tem essa versão. Tem a versão de que a pessoa não quer fazer nada, nada, nada. E, aí, eu acho que, não sei, acontece essa demissão mesmo. E tem o caso... bom, eu não sei. Não conheço as pessoas porque na época eu não estava aqui. E talvez tenha casos de quem não pediu e foi junto. Agora, por qual motivo eu não sei porque isso é entre você e o RH. Entre você e o gestor. Não dá para saber como que é. Tem pessoas que 'ah, eu pedi'. Pessoas com LER que adoraram [ser demitidas] porque era um objetivo que a pessoa tinha. Mesmo estando limitada, ela queria sair. Agora, você vai ficar com funcionário que está pedindo para sair, mesmo devido a ter LER, insatisfeito?"

$\mathrm{Na}$ verdade, relatos como este mostram que o discurso empresarial é aceito, senão por todos, pelo menos por uma parte significativa do grupo operário. A alegação de que às trabalhadoras lesionadas demitidas faltava "comprometimento" foi replicada na voz de muitos trabalhadores como "encostadas" ou "inúteis". Além disso, as demissões e a maneira como muitos reagiram a elas na empresa pode ter tido um efeito "exemplar": outros trabalhadores, em situação semelhante, talvez pensem duas vezes antes de buscar tratamento médico e afastamento de suas atividades profissionais. É necessário ir ao limite, talvez, para ter “comprometimento".

"Eles [a gerência] tomaram a gente como exemplo: 'Se aconteceu com essas, também pode acontecer com a gente'. Daí as pessoas ficaram com medo e começaram, assim - não é 'puxar o saco' - a criticar, a dar razão para a empresa, com medo de ser 
mandado embora também ${ }^{45}$. Tem gente que também está doente, mas não está fazendo tratamento com medo de descobrirem que elas estão doentes e ser mandadas embora. As pessoas trabalham com atestado no bolso." (Juliana, em reunião com trabalhadoras demitidas).

\section{A articulação entre financeirização, aumento da produtividade e intensificação do trabalho no depoimento de uma trabalhadora lesionada}

A discussão sobre as metas, a PLR e a introdução das mudanças na organização da produção da empresa sob os marcos do TPM permite ver os casos de lesões para além do drama pessoal concreto vivido pelas trabalhadoras lesionadas demitidas. As lesões aparecem, desse modo, como um efeito extremado da intensificação do trabalho, promovida pela busca de ganhos de produtividade por parte da empresa flexibilizada. As articulações entre flexibilização e intensificação do trabalho, lesões e a pressão externa permanente pela consecução das metas por parte do corpo impessoal de acionistas da empresa financeirizada podem ser encontradas no rico relato de Flor, uma trabalhadora com LER da Natura que não é parte do grupo de lesionadas demitidas e que segue, após o remanejamento de suas funções e tarefas, trabalhando na empresa.

Há 9 anos na Natura, Flor, que ainda não completou 40 anos, trabalhava como auxiliar de produção na fábrica "Rio Amazonas". Após desenvolver LER, passou a exercer, há dois anos, tarefas de apoio por restrição a trabalhar na área operacional. Quando a fábrica de Cajamar foi implantada, Flor, que mora próxima ao local, passou a ter interesse em ali trabalhar. Segundo conta, seu interesse deveu-se à proximidade geográfica e ao fato de que se tratava de uma empresa de cosméticos. Para atingir seu objetivo, ela voltou a estudar, concluindo o Ensino Médio - requisito para trabalhar na empresa - e ingressou na fábrica como temporária até ser efetivada 8 meses depois. Anos depois, Flor também concluiria uma graduação em Logística.

A entrada de Flor na empresa ocorreu no momento imediatamente anterior à introdução das células semiautônomas e do TPM, de modo que, diferentemente de muitas das trabalhadoras lesionadas demitidas, Flor não viveu o período de trabalho em Itapecerica. Ao notar que já não conseguia mais exercer suas tarefas como antes, Flor procurou a gerência em busca de outras tarefas.

\footnotetext{
${ }^{45}$ Juliana queixa-se, aqui, de que o grupo operário passou a criticar as demitidas e o sindicato, mas não a empresa.
} 
"Tenho lesão no ombro, o que me fez não poder mais continuar trabalhando na linha de produção. (...) E chegou a um ponto em que eu não conseguia mais trabalhar na linha. Eu fui ao médico, fiz exames, tenho laudo médico e cheguei e fui falar na gerência: eu fui contratada para trabalhar como auxiliar de produção e não consigo mais. Eu queria saber o que a Natura tem para mim de agora em diante. Porque meu objetivo não é sair na empresa, é crescer na empresa. Mas eu preciso ter uma função. Aí eu queria saber o que seria de mim. Daí eles começaram a montar alguns cargos porque não só eu [tenho lesão]. Têm algumas outras pessoas que têm esses problemas. Então têm cargos que são de pessoas que não podem trabalhar em linha.

(...) Eu saí da linha. Comecei a auxiliar o analista de turno, saber o que rodava nas linhas, os problemas que têm nas linhas e até a fabricação, sabendo o que está sendo produzido. Cartão de ponto, atestado... O dia que ela não podia vir [a colega responsável pela função], eu sempre vinha para o RH trazer. Então sempre tinha alguma coisa para fazer. Mas não uma função certa. Só que, semana passada, a coordenadora da produção - como uma colaboradora nossa foi promovida, ela vai para outro cargo, então como precisa alguém para o cargo - ela me convidou e eu vou ajudar [a coordenadora] na parte (...) de documentação, preenchimento de ficha, de limpeza, de sanitização, gráficos, como está a documentação, alguns produtos, que é prioridade para a limpeza, sempre controlar o estoque de segurança. Agora eu estou começando a pegar as coisas que eu vou fazer. E também trabalhava com treinamento, com pessoal, quando era necessário um treinamento, eles pediam para mim. Eu montava o treinamento, passava para os coordenadores e depois para os colaboradores. Então, sempre fui ajudando os coordenadores com o que eles me pediam”.

[Thiago Aguiar] Você acha que foi satisfatória a resolução da questão pela empresa ou você teve contratempos nessa situação toda?

"Da empresa, não [tive contratempos]. É mais das pessoas ao redor. Porque da empresa nem tem como. Tem a prova, tem laudo médico, têm exames, então, não tem como contestar. Agora, com pessoas, aí já é difícil. Porque com pessoas às vezes é 'será que é mesmo?'. Então, eu já ouvi de pessoas 'ah, então eu vou ao médico para ver se eu consigo me afastar e sair da linha'. (...) Então, nessa parte, eu fiquei muito chateada sim. (...) Você percebe. Você ouve isto. Eu não sei [o porquê da discriminação pelos colegas]. Lidar com pessoas, com o ser humano. É diferente. Um é diferente do outro. Então, você sempre vai ser isto. Esta parte eu não sei te responder o que leva as pessoas a pensarem assim e a agirem assim não. (...) Acho que sempre vai ter [competição no interior do grupo de trabalhadores]. Se eu falar que não... Nem sei se eu estou falando demais. O que eu sinto, o que eu vejo, eu já falei com os coordenadores... É o que eu falo para as pessoas mesmo. Sempre tem competição entre as pessoas em qualquer área. Tanto na linha como onde eu estou porque, se você sai de um lugar e vai para outro, a pessoa para chegar naquele grupo, sempre vai ter alguém ameaçado. Então sempre tem. Sempre vai ter competição. Geralmente, as pessoas têm medo, né? 'Ah, a pessoa é mais inteligente'... Por exemplo, eu ajudo uma colega na minha. Aí, chegavam pessoas e falavam: 'cuidado' - o pessoal me chama de 'loira' - 'a loira vai tirar o seu lugar'. Então, as pessoas começam a atrapalhar um pouco, né? Eu falo para ela: pode ficar tranquila. Eu não quero tirar o lugar de ninguém. Só estou fazendo o que pode ser feito".

Assim como as lesionadas demitidas, Flor - que ao contrário destas afirma não ter vivenciado problemas com a gerência - não encontrou solidariedade de seus colegas. O descrédito com sua situação e o medo de que pudesse "tirar o lugar" de alguma das pessoas com que ela trabalha em suas novas funções de apoio são apontados por ela como as principais dificuldades enfrentadas. Ela afirma que talvez, por reações deste 
tipo da parte dos colegas e pelo medo de perder o emprego, muitas outras trabalhadoras lesionadas escondem sua situação e tentam ir ao limite físico.

"Eu não cheguei a ser afastada pelo INSS. Não sou operada. Eu falei para eles que eu não queria chegar a esse ponto de operar. (...) Se o médico falasse que é $100 \%$ [de chance de cura], eu faria. Mas a gente sabe que não é. Tive sim uma carta do INSS para eu afastar. Mas eu cheguei antes com o analista e conversei. (...) Há pessoas que não vão atrás. Não sei se por medo. Lógico, que no começo eu também tinha medo: ah, não sei se eles vão me dispensar. Não vou poder mais ficar aqui. Mas eu pensei assim: não posso deixar chegar ao limite. Então, eu penso que cada um tem que correr atrás do melhor para si o mais rápido possível. Foi o que eu fiz. Mas têm pessoas sim, que vão levando: 'ah, não tô aguentando de dor'. Vai à base de remédio. Porque o remédio, basicamente, mascara a dor. Aí você vai trabalhando e lesionando mais. E eu não queria ficar dependente disso. Então, foi daí que eu resolvi ter a atitude que eu tive. (...) Elas falam: 'ah, eu tô bem assim'. Não sei até que ponto elas acham bem, mas é o que as pessoas falam. Cada um tem que ir atrás do seu melhor. Eu fui atrás do meu o quanto antes. E falo: gente, o problema, você tem. Qualquer pessoa pode ter. Você não pode deixar o seu piorar."

Flor, em seu relato, associa o TPM e as mudanças na produção, cuja introdução na nova planta de Cajamar ela vivenciou em tempo real, à intensificação da produção. De forma bastante perspicaz, ela mostra ter plena noção da relação entre as metas propostas para os trabalhadores e as exigências do aumento dos lucros por parte não apenas da direção da empresa, mas também dos acionistas sobre esta (o que, aliás, o gerente Roberto Andrade também fizera ao admitir que os acionistas colocariam a direção da empresa "na rua" caso os resultados financeiros da empresa não fossem suficientes).

Tratando de seu cotidiano no trabalho, Flor consegue mostrar concretamente em que consiste a "pilotagem pelo fim", de que fala Durand (2003), ao mencionar o crescente condicionamento da produção ao mercado na produção organizada pelo "fluxo tensionado". Ao mesmo tempo, os casos de lesão e a pressão pela intensificação do trabalho aparecem em sua fala relacionados à busca crescente pelo aumento da produtividade e dos lucros, inscrita nas metas propostas anualmente pela empresa.

[Flor] "Eu sempre trabalhei no envase. Aí, depois de uns dois anos em que eu estava à noite, veio este sistema de GSA [células semiautônomas]. Aí começaram as células, cada linha seria uma célula, onde teria o monitor de pessoas, o monitor de segurança, tinha o de meio-ambiente e o de performance, onde a gente sempre tinha de conversar. $\mathrm{O}$ [monitor] de performance cuidava da produção, o de segurança sempre via os problemas da linha, algum acidente, quase acidente, o de pessoas a marcação de férias, olhar faltas".

[Thiago Aguiar] Depois dessas mudanças, o ritmo de trabalho aumentou ou diminuiu? 
[Flor] "Aumentou. Porque, com o TPM, as linhas começaram a melhorar, aumentar a capacidade delas, e também a gente começou a ter metas. E isto aumenta sim a sua produtividade, a sua produção. (...) A gente não entendia, antes, como era feito [o processo de organização da produção]. Então, em reuniões com a gente, eles começam a falar que tem pedido da consultora, que vai para fora, então tem o tempo de entrega. Aí a gente começou a entender isto. (...) Agora tem a nossa coordenadora de produção. Ela passa o que vai ser feito tanto na fabricação como no envase. Então você sabe o que tem que produzir, a quantidade que você tem que produzir e o próximo produto. Agora é assim”.

[Thiago Aguiar] Você acha que as metas condicionam as atividades que vocês fazem e o ritmo de trabalho?

[Flor] "Bastante. Aumenta bastante. Porque aumentam as linhas, a velocidade. Têm linhas que antes tinham mais pessoas e agora são menos. E são linhas pesadas, na época que eu trabalhava, que era válvula, que é produto muito pesado. Têm algumas que é o robô que faz o serviço. A automatização tá vindo aí para tirar um pouco dos lugares, né, que eram das pessoas. Mas temos bastante linha. A gente vai, em média, em 15 pessoas num produto só. (...) Com o TPM, as máquinas ficaram melhores, cada vez fazendo mais melhorias para a máquina e aumentando a sua capacidade. Daí foi aumentando, também, as metas, é lógico, né? (...) Nós mesmos [controlamos o que se fará na produção]. Já tem uma programação da semana, que a coordenadora passa, que também pode mudar, de acordo com o dia ou com a semana dependendo do (...) pedido dos consultores, mas a gente já sabe. 'Oh, atingimos esta. Mas eu não tenho a próxima sequência! Ah, dá para pular uma, tem todo o material?'. Aí tem que olhar se tem todo o material, tem que olhar tudo isto."

[Thiago Aguiar] E como você avalia as metas anuais?

[Flor] "O meu modo de pensar é um pouco os dois lados. Eu gosto de pensar os dois lados. A gente sabe que a PLR da Natura é uma das maiores que têm. Antes, não tinha meta; agora tem. E por que tem meta? Porque agora a Natura virou uma empresa de ações. Então, têm acionistas, vai ter que entregar dinheiro. Eles querem a parte deles. A gente sabe que por lei, a gente poderia só receber um valor fixo, né? Então, se tem um valor a mais, a empresa é lógico que vai colocar as suas metas. É ruim? Se você for pensar, é. Vamos supor: se o valor é de 5 mil. 'Ah, mas eu não vou atingir a meta, eu não vou ganhar tudo isto'. Mas a gente trabalha numa empresa que abriu, expandiu para o mercado então a gente tem que viver esta parte. É que realmente a maioria está mal acostumada. Muita gente vem trabalhar aqui apenas pela PLR. E quando começa a ver que não tem mais aquilo lá, têm pessoas que querem sair sim porque acham que isto é o diferencial. Era. Agora, já não é tanto mais”.

\section{[Thiago Aguiar] Por que querem sair?}

[Flor] "Mais [pelas exigências d] as metas mesmo. Exigência de mercado. Ou, às vezes, as outras empresas crescem mais. Não que a Natura caia: ela deixou de atingir, de crescer um pouco mais porque é muito difícil uma empresa dessas falar: 'ah, a Natura não cresceu'. Não. Ela só não cresceu o que ela queria ou a porcentagem que ela queria. Então, para ela, não cresceu. Eu gosto de ler para entender um pouquinho essas partes".

A abertura de capital e as exigências de aumento da produtividade para uma distribuição superior de lucros e dividendos foram apontadas, por exemplo, por Thomas Coutrot (1998), como uma espécie de "incursão do mercado na produção", um dos fatores decisivos na explicação das mudanças nos modelos de organização do trabalho na nova "empresa neoliberal". François Chesnais (1996) mostra que, com o aumento do 
"capital fictício" sob as novas formas de acumulação capitalista na etapa da "mundialização do capital", o comportamento das empresas e de seus investimentos passam a ser ditados mais e mais pela esfera financeira, o que reduziu as margens temporais da valorização do capital - o que ele chama de "short-termism" - e trouxe a introdução das Tecnologias de Informação e Comunicação (por ele chamadas de "teleinformática") e das mudanças na produção conhecidas por toyotismo. Trata-se da "estratégia tecno-financeira" pela qual o capital financeiro, em sua busca desenfreada pela liquidez monetária e pela valorização do capital no menor tempo possível, introduz na produção um "regime do tacão de ferro", baseado "no recurso combinado às modalidades clássicas de apropriação da mais-valia, tanto absoluta como relativa, (...) dirigidas a obter a máxima intensidade do trabalho e o máximo rendimento de uma mão-de-obra flexível” (CHESNAIS, 1996: 16-17).

Várias das características levantadas por Chesnais e Coutrot para descrever o período da mundialização e a empresa neoliberal financeirizada podem ser encontradas na Natura, um grupo que abriu seu capital, internalizou-se e modernizou sua produção sob os marcos da "estratégia tecno-financeira" e das "novas formas de investimento" Não deixa de ser eloquente, portanto, a associação feita por Flor, uma auxiliar de produção da empresa, entre metas, PLR, intensificação do trabalho, lesões e a pressão dos acionistas pelo ganho financeiro.

O caso das demissões de trabalhadoras lesionadas na Natura, por sua vez, parece ser parte de um processo mais amplo de substituição gradual do quadro da empresa: substituição de uma geração por outra, nos marcos de Beaud e Pialoux (2009). Trabalhadoras antigas, que vivenciaram o crescimento da empresa e a transição para uma nova planta, submetida a novas formas de organização da produção, podem, caso não se enquadrem nos novos critérios que a empresa considera adequados, ser prescindíveis. É necessário debruçar-se, então, sobre a visão que a empresa constrói de si mesma e de tais critérios, além de avaliar de que maneira estes são recebidos pelo grupo operário.

\footnotetext{
${ }^{46}$ Como na compra do controle acionário da empresa australiana AESOP, mencionada no capítulo 1.
} 


\section{Trajetórias ilustrativas}

Nas reuniões com as demitidas, chamava a atenção a presença de uma trabalhadora em particular. Apesar de não ser sindicalista, convocava e organizava as reuniões, propunha iniciativas e até acabava animando alguma colega, durante a reunião, se esta começasse a chorar ao falar de suas dificuldades. Trata-se de Marilda, uma antiga trabalhadora da Natura, que busca aposentadoria por invalidez. Por intermédio dela, foi possível conhecer e entrevistar algumas das trabalhadoras lesionadas e, por meio da rede de contatos daí construída, foi possível conhecer Richard, um jovem trabalhador da empresa, que estava finalizando seu curso superior à época do contato.

Pelas diferenças de idade e trajetórias, parece ser interessante tratar das opiniões desses dois colegas sobre sua visão do trabalho e da empresa. Evidentemente, apesar de instigante, não se pretende mostrar o contraste como uma polarização esquemática de opiniões que percorreria o grupo operário. No entanto, a diferença geracional e suas consequências parecem bastante eloquentes sobre o que se pretende discutir, posteriormente, a respeito da ascensão de um novo grupo operário, ou "nova condição operária”, animado pela nova empresa global de capital nacional.

O contato com Marilda deu-se por intermédio do Sindicato dos Químicos de Osasco. Tratava-se de uma trabalhadora afetada por LER, afastada do trabalho na Natura e que aguardava homologação de seu pedido de aposentadoria por invalidez. Marilda não fazia parte do grupo de trabalhadoras demitidas. Com pouco mais de 50 anos e quase 20 de Natura, Marilda começou a trabalhar na antiga fábrica de Itapecerica da Serra.

"Comecei trabalhando em Itapecerica da Serra. (...) Lá era fábrica e tinha um centro de distribuição em Santo Amaro. Centro de distribuição para vendedoras. Fabricavam lá e mandavam para Santo Amaro e de lá faziam a distribuição para outros locais. Na fábrica, não podia aumentar mais porque era área de manancial. Então, o que eles fizeram? Vieram para Cajamar. (...) Demoraram mais ou menos 3 anos para vir para Cajamar. Entregaram o prédio de Santo Amaro e ficaram com o prédio de Itapecerica. Transferiram de Santo Amaro para Itapecerica [a distribuição] e, em Cajamar, fábrica. Na verdade, tudo começou mesmo, a fábrica, na João Dias, em Santo Amaro, mas eu não sou dessa época, mas as mais velhas comentavam”.

Os primeiros problemas de saúde no trabalho começaram ali, na antiga fábrica da empresa. Marilda viveu o período de transferência para a nova planta de Cajamar e a 
implantação, por exemplo, do regime de metas e da PLR. Para ela, ao longo dos anos, houve uma grande intensificação do trabalho. As metas individuais, por sua vez, são vistas por ela como injustas, na medida em que diferenciam os rendimentos de trabalhadores da mesma empresa.

"Uma coisa que eu sempre achei errado: você trabalha na mesma empresa, você ganha um x, eu ganho outro (...). Não é a mesma para todo mundo. Eu sempre achei isso super errado porque se você faz um desempenho, você faz, se eu faço um outro desempenho, eu estou ali na mesma empresa (...). Tem essa desigualdade que eu não concordo. Acho muito errado".

A doença de Marilda ao longo do tempo piorou e ela precisou de afastamento pelas dores crônicas que sentia.

"O meu caso é crônico tanto é que eu me afastei porque eu precisava tomar remédio. Tomava remédio à noite para trabalhar durante o dia. Ou então, à noite, eu não aguentava a dor nos braços e tomava o remédio. Então, eu fui tomando medicamento e o médico me falou: 'Olha, Marilda, você foi tomando remédio que era para amenizar, mas não é tratamento'. Então, ficou crônico. (...) Eu tenho tendinite nos dois braços, nos pulsos e nos ombros".

Marilda tem referência no sindicato de sua categoria. Quando se afastou do trabalho, passou a contribuir como uma espécie de diretora de base informal do sindicato. Ela é uma colaboradora ativa, mesmo sem compor a diretoria, que participa do cotidiano da entidade e ajuda numa série de atividades. Para ela, isso é uma forma não apenas de ocupar o tempo, mas de sentir-se ativa. $\mathrm{O}$ sindicato aparece como um grande desafio, um aprendizado, e uma possibilidade de auxiliar suas companheiras, na empresa de onde veio e mesmo em outras empresas.

"No momento, eu faço parte do sindicato. Qualquer empresa, a gente vai, negocia, eu só não posso assinar. Eles falam para eu ser parte, mas eu estou pensando... Porque é um trabalho sério, não é brincadeira, tem uma responsabilidade e tem poucas pessoas para atuar no sindicato, sabe? São muitas fábricas, muitas fábricas, e muita cobrança. Então, é um compromisso, eu penso assim, apesar de eu ser aposentada, eu gosto, sabe? Para ter conhecimento, conhecer coisas que você nem imagina, sabe? Ajudar as pessoas. Isso é muito importante. Tem meninas que não conseguem falar com o encarregado. Então, a gente liga, numa boa, e pergunta o que aconteceu (...). Porque eu gosto mesmo de ajudar. Se eu pudesse, se me colocassem hoje numa linha de produção, eu trabalho. Eu sei que eu não vou aguentar, mas eu trabalho. Eu não gosto de ficar à toa. Isto me deixa mal". 
Por também estar acometida de doença do trabalho, Marilda identifica-se com o caso das demitidas e é umas das "diretoras" do sindicato que atua na organização das demitidas, na tentativa de reintegrá-las ou de tentar mitigar ${ }^{47}$ seus efeitos.

"O que eles querem acabar é com isso, com essa "salinha" - eles chamam de "salinha" - que é o local onde ficam as meninas reabilitadas e querem colocar na linha. Chegou do INSS, vai para a linha e acabou. Aguentou, aguentou, não aguentou, tchau. (...) Eu fico revoltada porque as mulheres que saíram tinham de 35 para cima e o mercado de trabalho não tem vaga a não ser que seja para outra atividade. Então, a luta está acontecendo, mas eles não querem negociar”.

No entanto, Marilda sabe que há uma dificuldade grande para mobilizar os outros trabalhadores da empresa. Há algo na Natura que atrai a lealdade da maioria do grupo operário. Mesmo ela, acometida por LER em seus anos de trabalho na empresa, que pleiteia aposentadoria por invalidez e questiona as metas e a PLR, tem a opinião de que se trata de uma boa empresa para trabalhar e estima o fundador da companhia, Luiz Seabra.

"Quem está lá acha que é o melhor emprego do mundo porque é uma boa empresa. Não vou dizer para você que não. E o dono, que fundou a Natura, é uma pessoa espetacular. A partir do momento em que ele passou a bola para outras pessoas, começou a ser isso que é hoje. Porque eles começaram a ver o quê? Grana. Ele não. Ele é uma pessoa super humana. Então, a empresa não era tão grande, mas tinha restaurante, tudo. Depois que ele passou a bola para acionistas ${ }^{48}$... Agora tem mais dois que fazem parte também. O Seabra é o fundador. Tem mais dois. (...) São coisas que você avalia e vê que é uma boa empresa".

Richard talvez seja um dos trabalhadores que Marilda tem em mente ao afirmar que muitos trabalhadores da Natura sentem-se trabalhando numa boa empresa. Richard tem 28 anos e trabalha há 7 na Natura. Trabalhador do turno noturno, marca a entrevista num hipermercado, perto de sua casa, na Zona Sul de São Paulo no começo da tarde - o momento do dia em que ele não está trabalhando ou dormindo. Mais especificamente, combinou-se o encontro nas mesas de uma lanchonete internacional de fast-food. Literalmente "vestindo a camisa", Richard aparece com uma camiseta polo com o logotipo da Natura bordado no peito ${ }^{49}$, carregando nas mãos a chave de seu carro e

\footnotetext{
${ }^{47}$ Por exemplo, através das negociações com a empresa para tentar fazer com que as trabalhadoras muitas das quais com cirurgia agendada - mantivessem o convênio médico por um período maior.

${ }^{48}$ Curioso observar que Marilda, tal como Flor, relaciona a presença dos acionistas à piora nas condições de trabalho na empresa.

${ }^{49}$ Evidentemente, ainda que se possa imaginar uma série de significados, não se pode extrair de imediato nenhuma conclusão a respeito da camiseta do entrevistado. Richard pode simplesmente tê-la vestido para facilitar sua identificação ou por qualquer outro motivo. Quem sabe, ainda, por motivo nenhum - a
} 
alguns boletos bancários. A necessidade de pagá-los, em especial a prestação do carro, segundo diz, faz com que a entrevista não possa alongar-se por muito tempo. Bem disposto, Richard simpatiza com o fato de que está conversando com um estudante universitário de pós-graduação. Logo diz estar quase concluindo o curso de FarmáciaBioquímica, numa faculdade particular da Zona Norte há dezenas de quilômetros de seu local de trabalho e de sua residência. Richard conta as dificuldades por que passou nos primeiros anos, trabalhando à noite, fazendo muitas disciplinas na faculdade e tendo que passar boa parte do dia em deslocamentos do extremo sul da cidade a lugares tão distantes dali como Cajamar e Santana.

A princípio, Richard fala sobre a organização da produção na empresa, a maneira como se distribuem as tarefas na célula, as metas e a PLR. Manipulador, sua célula fabrica o cosmético e o envia para envase. As metas são vistas por ele como um bom estímulo para que o trabalhador não fique estagnado e "corra atrás", além de proporcionar um bom rendimento se comparada ao que se paga noutras empresas.

"A gente tem metas definidas pela Natura (...). O analista faz a planilha e envia pra gente. O máximo que o monitor pode fazer é organizar. A planilha já vem feita. A gente se organiza para ver quem vai fazer cada produto. Hoje, eu vou fazer um hidratante e você vai fazer um desodorante (...). A planilha já vem feita. Ela é semanal”.

"A PLR tem um valor, mas que é estipulado pelas metas da empresa, $50 \%$ das metas da empresa, e $50 \%$ das metas dos funcionários. Se, no final, a empresa se sair bem, conseguir as metas dela e a gente não conseguir os nossos $50 \%$... A gente tem que conseguir os nossos 50\%. Só assim a gente tem os $100 \%$ da PLR. (...) A PLR da empresa eu vejo como boa, pelo valor, comparativo com outras empresas de pessoas que eu conheço, pelo valor, ela é ótima. Tem a diferença de você ter as metas, mas se deixar fixo, fica meio estagnado, é um jeito de a gente correr atrás: 'Tá chegando o final do ano. Vamos correr atrás! Vamos faltar menos'. Isso é um estímulo, é um estímulo para a gente. (...) Se um falta, prejudica os outros. Não tem como um [trabalhador] não alcançar a produção. A minha célula, se ela não alcançar a produção - a minha célula é composta pelos funcionários dos três turnos - se a minha célula não alcançar a produção, só ela é prejudicada. Se eu e os meus 10 colegas, a gente fizer corpo mole, então não é justo prejudicar a Natura toda, a fábrica toda. É só a minha célula prejudicada".

Desse modo, Richard parece concordar com a visão empresarial a respeito do aumento da produção como um estímulo individual: "correr atrás" para alcançar as metas e observar o trabalho dos colegas para que todos saiam ganhando. Pode-se dizer, também, que se trata de um trabalhador exemplar em termos do "comprometimento"

camiseta pode ter sido simplesmente a primeira que ele encontrou em seu guarda-roupas. O fato é que, durante a entrevista, me abstive de perguntar o motivo, mas não consigo lembrar da conversa sem imediatamente rever sua elegante camiseta polo bordada com o logo da Natura. 
que faltou, segundo a empresa, às trabalhadoras lesionadas demitidas. Aliás, ele afirma não saber do caso das demitidas e nem se existem pessoas lesionadas trabalhando. "Sobre essa questão dos demitidos, têm visões diferentes. Eu tenho uma, a Marilda, que é do sindicato, tem outra" (anotação de caderno de campo ${ }^{50}$ ).

Além disso, ele acha importante conversar com quem aparente estar "fazendo corpo mole" na produção para resolver a situação.

"Se a gente vê que tem alguém fazendo corpo mole ou tá faltando muito, ou não entrega o processo, ou fico enrolando, não sei... A gente pode se reunir e conversar com você. A gente da célula (...) A gente não precisa falar com o chefe. A gente pode se reunir entre a gente e conversar. Se não resolver, aí a gente pode passar pro superior".

"Não tenho conhecimento não [a respeito de trabalhadores com lesão na empresa]. Eu ouvi um papo desse aí. A gente sabe disso por causa do jornalzinho do sindicato. Mas, na minha fábrica, as pessoas, que trabalham com lesão, não têm. As pessoas às vezes saem da Natura e vão lá reclamar às vezes por outra lesão (...). Se voltou, é porque o médico libera. Volta porque o médico libera. Agora, pessoas com lesão repetitiva, pelo menos no meu setor, eu não vejo pessoas com isso não".

Um ano após a entrevista com Richard, soube-se por Marilda que ele havia saído da Natura e que estaria trabalhando na AVON, histórica concorrente da empresa no setor de cosméticos. Não foi possível, infelizmente, retomar contato com ele para saber o que teria motivado sua saída. No entanto, Richard, um jovem que "vestia a camisa", não foi o único exemplo encontrado na empresa de trabalhador que se sente estimulado pelas metas e acredita que, pelo esforço no trabalho e pela educação, poderá ascender em sua carreira na companhia.

Aurélia, como Richard, também é estudante de Farmácia numa faculdade privada. Com 25 anos de idade, ela trabalha há 6 na fábrica "Rio São Francisco". À primeira vista, logo no início da entrevista, as profundas olheiras da jovem chamaram a atenção. Quando entrou na empresa, Aurélia vivia em Cajamar, mas ela mudou-se para Campinas ao casar-se. Hoje, tem uma filha de 2 anos e vive uma rotina pesada, pois acorda muito cedo para ir ao trabalho de ônibus fretado e, ao retornar a sua casa, precisa cuidar da filha e da casa.

Aurélia, apesar de jovem, também desenvolveu lesão em seu braço. No entanto, ela afirma que a empresa esforça-se para evitar que os trabalhadores lesionem-se e que seu problema deveu-se especialmente a uma sobrecarga por conta da filha.

\footnotetext{
${ }^{50}$ Quando tínhamos terminado a entrevista e o gravador foi desligado, Richard voltou a falar sobre algumas questões tratadas anteriormente. Elas foram registradas em caderno de campo.
} 
"Eu vim ter este ano [uma lesão]. Tive uma inflamação no meu braço. Foi meio chatinho. Mas também por conta de sobrecarga, a nenê está mais pesada. Tudo isto influi. Não só por conta do trabalho. Também por outras coisas. Eu acho que eu quero virar o mundo de ponta-cabeça em 24 horas. Então durmo muito pouco, é exaustivo. Então, tudo isto ajuda. Não só pelo trabalho, mas pela minha vida lá fora. Eu durmo muito pouco. (...) Graças a deus é muito bom [trabalhar na Natura]. (...) Aqui, a Natura pensa na ergonomia, que é a troca de postos de trabalho, pensa na saúde do funcionário. Aqui a gente tem o ambulatório, que a gente pode fazer Fisioterapia. Pode passar aqui para não precisar passar fora, se deslocar do trabalho, fácil acesso. Tem um berçário para as mães, que ajuda muito. Então, é maravilhosa".

É interessante notar que Aurélia, ao falar sobre a lesão, parece dissociar sua vida no trabalho e fora dele. É como se a lesão tivesse ocorrido por uma espécie de predisposição individual a "virar o mundo de ponta-cabeça em 24 horas". Sua dedicação aos estudos, no entanto, como tentativa de progredir na carreira, é estimulada pela empresa e parte da difícil rotina de Aurélia, que a leva a dormir pouco.

Trabalho com movimentos repetitivos, deslocamentos diários consideráveis, combinação entre trabalho e estudo como forma de alcançar progressão na carreira, dupla jornada de trabalho pelo fato de ser mãe: tudo isto é parte dos condicionantes da vida de Aurélia, jovem trabalhadora lesionada. Como faz faculdade no período noturno em Campinas, ela dorme cerca de 4 horas por noite. Mesmo assim, planeja começar uma pós-graduação no horário vago assim que conclua a graduação. Afirma que, dessa forma, será mais fácil pleitear uma promoção interna ou, não conseguindo, buscar uma melhor colocação em outra empresa.

"Levanto 10 para as 4 da manhã. Vou dormir 11 e meia, meia-noite. Todo dia é esta rotina. Faço [a faculdade] das 7 e 15 às 11 [da noite]. É cansativo. Não é fácil. (...) Eu estipulei uma meta. Quando eu entrei, em 2007, eu entrei sonhando em fazer minha graduação na Natura. Eu não conhecia nada, não sabia nem como era a área de produção e aí eu fui conhecendo aos poucos. Comecei fazendo Fisioterapia, que eu queria no início. Depois, eu fui conhecendo e mudei. Resolvi fazer Farmácia. Espero ter uma oportunidade aqui até o meio do ano que vem. Se eu não conseguir uma oportunidade, estarei saindo [da empresa].

(...) A Natura oferece uma bolsa, né, para a pós $50 \%$ ela cobre o valor da sua mensalidade e a mesma forma com a graduação. Ela me ajuda com 70\%”.

A Natura estimula que os trabalhadores continuem estudando. O diploma de ensino superior pode facilitar a promoção interna, na medida em que este quesito melhora o desempenho na seleção por alguma vaga que eventualmente seja aberta, especialmente em cargos de gestão na fábrica ou administrativos, como explica Susana Diniz:

"Na fábrica, a primeira exigência é o $2^{\circ}$ grau completo. A gente faz provas, a gente faz uma prova de conhecimento geral em que tem três perguntas de atualidades, as quatro operações, uma redação para a pessoa poder falar sobre ela e tal. Para a gente entender um pouco o raciocínio lógico, o posicionamento, o conhecimento. Então, é 
uma primeira triagem bem simples (...) Na produção, não [é necessário ter ensino superior]. Em cargos de gestão dentro da fábrica, todos são de nível superior. Na área administrativa, todos têm ensino superior".

É possível ver, desse modo, a expectativa de progredir na carreira e obter uma colocação melhor na empresa nas vozes de muitos dos trabalhadores entrevistados.

"Não deu para iniciar agora a minha pós[-graduação], mas para frente [talvez] eu consiga, né? E conseguir um cargo melhor. Sou formada em logística e eu ia iniciar uma pós em inteligência da produção, administração da produção seria, né? Mas não deu porque só tem aos sábados e eu trabalho aos sábados alternados. Aí eu não ia conseguir. Então, quem sabe, (...) eu volte a repensar [no futuro] essa parte da pós". (Flor)

"Olha, na produção eu vejo que infelizmente a gente é olhado da mesma maneira. Tanto as pessoas que estudam como as que não estudaram. Não tem muito o que diferenciar. É mais o interesse seu: eu quero a vaga, então eu estudei para ela e vou tentar, mas de resto a gente é visto da mesma maneira. Não tem diferença não. (...) Eu pretendo crescer na área que eu estudei aqui mesmo. Não tenho vontade de sair daqui até porque faz pouco tempo que eu me formei e eu acredito que noutra empresa é muito difícil conseguir também, de cara, virar uma química, mas eu pretendo crescer aqui mesmo". (Mônica, 22 anos, graduada em Química, auxiliar de produção na fábrica "Rio São Francisco”)

Mônica, Richard e Aurélia são parte de uma nova geração de trabalhadoras da Natura: jovens, aparentam disposição a aceitar as metas e a buscar o sucesso no interior da empresa, através dos caminhos abertos pela gestão, como o estímulo a realizar graduações ou pós-graduações, com vistas a encontrar outra colocação e, portanto, melhores rendimentos. As falas dos três, a seu modo, parecem mostrar sintonia com as metas e expectativas da empresa sobre o "comprometimento" que teria faltado às lesionadas demitidas.

Antônio, almoxarife na fábrica "Rio São Francisco", está na empresa há 23 anos. Também começou na Natura jovem, aos 19 anos, através de indicação feita por seu pai, antigo almoxarife da empresa, após este demitir-se para voltar a sua terra natal, a Paraíba. Antônio é parte de uma geração mais antiga de trabalhadores da empresa. Amigo de Marilda, ele também é diretor do Sindicato dos Químicos e conhece, pela experiência anterior de seu pai na fábrica e por sua longa trajetória profissional na empresa, muitas histórias do passado.

Em entrevista, por exemplo, Antônio contou a história de Raimundo, um amigo de seu pai, que trabalhou na Natura desde os primórdios da empresa. Antônio diz que Raimundo auxiliou Luiz Seabra, o fundador da companhia, cuja trajetória será objeto de discussão no próximo capítulo, diversas vezes naqueles tempos, inclusive emprestandolhe dinheiro para pagar contas da empresa. Com indignação, Antônio afirma que 
Raimundo foi demitido por telefone, após 35 anos de trabalho, num período de reestruturação da empresa, quando estava em casa, dispensado do trabalho por atestado médico após fazer uma cirurgia de varizes.

"Ele emprestou dinheiro para o Seabra. Quando ele entrou na Natura, a Natura estava começando ainda. (...) Quando ele começou na Natura, a Natura tinha uns 4 anos de existência. Era a época das vacas magras mesmo, quando o Seabra tinha um Fusca, ou uma Brasília ainda, e ele emprestava dinheiro para o Seabra pagar conta de água, de luz. Era empregado da Natura. (...) Quando ele foi mandado embora, ele tinha quase 35 anos de empresa e ele foi mandado embora em casa, com atestado médico. (...) Foi quando a Natura fez uma reestruturação. (...) E os caras ainda tiveram a cara de pau de chamar ele para entregar o presente para o Seabra nos 40 anos da empresa. É um cara que se você conversar com ele, ainda hoje mesmo, ele não tem ressentimento nenhum. Ele defende a empresa. (...) Ele foi mandado embora com atestado. Ele fez uma cirurgia, ele tem um problema de varizes. E como ele é forte, é alto, e lá tem que subir muita escada, ele não estava se sentindo muito bem. Então, ele pegou e se afastou. Nessa época, a Natura pagou [ao demitir] 1 mês de salário para cada ano trabalhado a todos e contratou uma empresa para encaixar estas pessoas em outras empresas. Aí, ele estava em casa e esta empresa ligou para ele, para encaixá-lo em outra empresa. Ele nem sabia que tinha sido mandado embora da empresa. Mesmo sendo amigo do dono da empresa [Luiz Seabra]. Que nem o pessoal fala: ele tinha emprestado dinheiro para o homem para pagar conta de água, de luz. Todo mundo sabe. Ele mesmo contava isto aí. Por isso é que a gente fica meio indignado com certas coisas. (...) Quando tem a assembleia, eu conto no microfone esta história. Tem o caso do Raimundo... Eles [da gerência da empresa] ficam doidos, né, porque foi um erro... Várias vezes, tentaram mandar embora. Mas quando não tinha acionista, o Seabra, que é este que a gente está falando, todas as vezes barrou, não deixava dispensar ele. Mas, na época que passou a ter acionista, aí não tem mais como..."

Referenciado no sindicato e contratado no período anterior à reestruturação da empresa, Antônio tem outra visão a respeito da contratação de pessoal mais escolarizado e do estímulo ao aumento da escolarização do grupo operário por parte da direção da empresa.

"A Natura hoje tem muita gente nova, pessoas que têm um estudo mais elevado. As pessoas antigas que ficaram, se quisessem ficar num cargo de operadora, foram obrigadas a fazer curso, foram obrigadas a voltar a estudar. Então tiveram pessoas que às vezes não aceitaram voltar a estudar porque tinham... Tipo assim: eu estou lá há 23 anos, aí eu não volto a estudar. [Outra pessoa] entra há pouco tempo, mas ela tem um estudo bem mais elevado que o meu. E aí ela é promovida. Ela passa a ganhar mais do que eu, entendeu? Isso aí eu vejo já como uma estratégia da empresa que obriga as pessoas a estar dentro do que ela quer, dos padrões deles. Porque isto para a empresa, para a imagem da empresa, as pessoas lá são tudo, no mínimo, segundo grau completo. [...] Depois de Cajamar se aprofundou mais ainda."

Na fala de Antônio, é possível vislumbrar a polarização, no que se refere ao tipo de socialização pela educação, apontada por Beaud e Pialoux (2009) entre as duas gerações operárias que passaram a conviver na Peugeot-Sochaux durante o período de reestruturação da fábrica nos anos 1980. Nesse momento, a empresa francesa passou a desvalorizar o papel dos cursos técnicos e das antigas qualificações dos OEs, e passou 
conscientemente a buscar um certo perfil de trabalhador jovem e escolarizado, cuja socialização se deu num outro momento histórico, de prolongamento da escolaridade da geração dos filhos dos operários, que os autores chamam de "bagagens um pouco pesadas", cujo peso seria sentido, no entanto, quando estes jovens passassem a lidar com o trabalho na fábrica e seus dissabores.

\begin{abstract}
"Os jovens técnicos representam um novo modelo de excelência profissional (baseado no domínio da eletrônica e da informática) e ao mesmo tempo social (disponíveis, dinâmicos, esportistas, 'apolíticos'). Suas disposições se formaram num contexto sócio-histórico diferente. Tendo feito cursos superiores (...) nos anos 1980, no momento da 'reabilitação das fábricas', eles interiorizaram perfeitamente os imperativos do just in time da competitividade industrial" (BEAUD e PIALOUX, 2009: 92).
\end{abstract}

Estas diferenças deram-se, no caso narrado por Beaud e Pialoux, não apenas entre antigos operários e técnicos com ensino superior, mas também entre antigos e novos OEs, já que a nova geração havia vivenciado uma espécie de "fuga para frente" no sistema escolar, permanecendo mais tempo na escola e frequentando não mais o ensino profissionalizante, mas o ensino geral de segundo grau. Tendo origem nas famílias operárias, no entanto, sua socialização e disposição para o sistema escolar, como argumentam Beaud e Pialoux, era bastante distinta daquela dos filhos da classe média, que se preparavam para ingressar no ensino superior.

Como a "fuga para frente" dos anos 1980 durava demais, logo os filhos da classe operária - que rejeitavam a herança de seus pais, não se identificavam com a cultura operária e nem queriam trabalhar na fábrica - acabariam percebendo que não podiam reproduzir a trajetória ascendente na classe média, ingressando na universidade, e ao final acabariam trabalhando na Peugeot, porém socializados em outros valores. Este choque entre as duas gerações foi eloquentemente descrito ao se abordarem as "contradições de um jovem operador". A "fuga para frente", desse modo, para muitos, acabou significando frustração pela impossibilidade de realizar as disposições e expectativas que a frequência no ensino geral havia trazido a esta geração.

Não se pretende, aqui, realizar uma transposição mecânica entre os casos francês e brasileiro, apenas marcar o interesse da empresa flexibilizada, aqui e alhures, de estimular a contratação de operários de um novo tipo, mais dispostos às exigências impessoais das metas empresariais, que se modificam velozmente com a concorrência permanente, a pressão dos acionistas e a intensa mobilidade do capital. Tal pano de fundo se apresenta socialmente no grupo de trabalhadores e gera conflitos. A concorrência por uma vaga no mercado interno da empresa certamente é um deles. 
Burawoy (1990), a partir do caso da fábrica Allied, mostra como o mercado interno das fábricas é um "aparelho de produção", que transpõe o individualismo da competição no mercado externo de trabalho para o interior do grupo operário na fábrica, sobrepondo interesses individuais aos coletivos e realizando, por conta das expectativas de ascensão profissional, uma espécie de coordenação de interesses entre o trabalhador e a gerência, o que pode trazer obstáculos ao desenvolvimento da solidariedade entre os pares e da ação coletiva.

"Eu sou formada em Química. Eu terminei na metade desse ano [de 2013], em junho. [...] Eu sigo na mesma função, mas só aqui tem um plano de carreira que a gente concorre às outras vagas, né, que chama 'As Minhas Escolhas'. Aí a gente presta a prova como se fosse em outra empresa mesmo. A gente presta prova, entrevista, dependendo da vaga tem dinâmica também. Mas como a exigência de muitas vagas era ser formada, então agora é que eu estou tendo mais oportunidades porque antes não dava para eu concorrer (...)". (Mônica)

Ora, as falas apresentadas aqui de vários trabalhadores parecem mostrar que o estímulo da Natura à escolarização, bem como as avaliações internas, o que se abordará a seguir, visam exatamente a realizar esta coordenação de interesses. Por outro lado, como se viu na fala de Mônica ao destacar que não havia diferença na fábrica entre trabalhadores com e sem Ensino Superior ou na fala de Aurélia que afirma esperar uma melhor colocação na fábrica ou dela sairá, é possível que haja frustração se a expectativa de ascensão interna não se processa.

"[Escolhi a Natura] porque tinha a ver com o que tinha começado a estudar. Logo que eu entrei aqui eu tinha acabado de começar a estudar. Eu pensei que... Eu pensei, não, se deus quiser logo eu vou estar na área que eu estudei. Como tinha a ver, eu decidi prestar para esta empresa. (...) Sempre todo mundo falava que era um ótimo lugar para trabalhar. Realmente, é um bom lugar para trabalhar, tem benefícios bons. A única coisa que é meio difícil é essa parte de subir de cargo mesmo (...)" (Mônica)

Então, é interessante, agora, tratar de como a Natura concebe seu regime de recrutamento e de relações com os operários ("colaboradores", na linguagem desenvolvida pela empresa). Segundo a representação da empresa, "a evolução da cultura organizacional tem por objetivo construir os alicerces da nossa Visão de Futuro, mantendo e reforçando a nossa Essência entre os colaboradores. Essa evolução se dará pelo alinhamento do comportamento dos indivíduos, das estratégias, planos, processos e rituais de relacionamento à cultura desejada" ${ }^{\text {. }}$. No que se refere à contratação de mão-

\footnotetext{
\begin{tabular}{lllll}
\hline 51 & Relatório & Natura & 2010. & Disponível
\end{tabular} http://scf.natura.net/Conteudo/Default.aspx?MenuStructure=5\&MenuItem=12. Maiúsculas no original.
} 
de-obra, a Natura - que em seu relatório ${ }^{52}$ a qualifica como "Atração e engajamento" afirma que "para garantir a efetividade de todas as mudanças que estamos promovendo na gestão de pessoas, é preciso contar com processos de recrutamento e seleção que tragam não só candidatos capacitados tecnicamente, mas que também possam se engajar à empresa por meio de propósitos e valores alinhados aos nossos" ${ }^{„ 53}$. A empresa, dessa maneira, parece interessada na contratação de operários de outro tipo (a começar pela maneira como se refere a eles ${ }^{54}$ ).

Como características marcantes da "Essência" apresentada pela empresa a respeito dela mesma, a responsabilidade social e o conceito de "bem estar bem" aparecem como parte da sua estratégia publicitária e também para difusão entre o grupo operário. Esse aspecto aparece em comum nas visões contrastantes de Richard e de Juliana, uma das trabalhadoras demitidas. As declarações de ambos terminam por demonstrar, por motivos opostos, que os discursos sobre a responsabilidade social e a respeito do "bem estar bem" são alheios ao trabalho em si e se referem a outros aspectos da produção, ou mesmo, principalmente, de fora dela. Ou seja, as questões propriamente relacionadas ao trabalho parecem ser mantidas distantes, "opacas", do discurso da "nova empresa" moderna, que prega a "transparência".

"Na fábrica, têm faixas em vários lugares sobre quanta água a empresa gastou e tratou. Tem orientação sobre como descartar o lixo, fazer reciclagem. Acho bom porque agora eu sei como fazer essas coisas de um jeito correto (...). Eles fazem palestras, em todos os lugares tem orientação sobre isso, economia de água, cuidado com a natureza. Lá todo mundo tem essa preocupação com o social (...). Quando a gente começa, a gente é meio ignorante, mas, depois, vai entendendo onde tem que jogar o lixo, fazer reciclagem, economizar água" (Richard, em declaração registrada em caderno de campo).

"Para quem está lá dentro da empresa, é uma coisa. De fora, é outra. As pessoas veem aquela coisa de 'bem estar bem' que passa todo dia. Aquilo ali não serve para dentro da empresa. É daqui para fora. Porque, quando as pessoas vão visitar a empresa, eles mostram a empresa de uma forma totalmente diferente. Eles mostram todo mundo contente, todo mundo trabalhando, mas não é nada disso. O 'bem estar' não é para o funcionário" (Juliana, em entrevista em conjunto com Darci).

Uma situação bastante eloquente era narrada pelas trabalhadoras a respeito das contradições do slogan "bem estar bem": exatamente um dia antes da demissão das

\footnotetext{
52 Idem.

53 Idem.

${ }^{54}$ Esse (a nova identidade de "colaboradores") é um aspecto recorrente de pesquisas na área, já que, conforme destaca Vera Telles, há uma relação entre a mudança no uso das palavras, modificações na tecnologia e na qualificação dos trabalhadores (TELLES, et al., 2006: 19). Beaud e Pialoux (2009) destacam o fato de que na Peugeot-Sochaux, no processo de modificação pelo qual a fábrica passou no final dos anos 80 , o uso da designação “operadores" em vez de operários foi incentivado.
} 
trabalhadoras lesionadas, houve uma festa promovida pela empresa. As trabalhadoras da Natura ganharam, como comemoração de fim de ano, esta festa e um dia no spa. As trabalhadoras que seriam demitidas no dia seguinte não foram convidadas à festa e nem receberam o prêmio do dia no spa, como todas as outras trabalhadoras. Para elas, esta foi uma situação muito humilhante, que sintetizou o modo como a empresa tratou-as durante o período em que atuaram na célula (a linha para as "readaptadas"). Após a ida da comitiva de trabalhadoras e do sindicato a Brasília e do caso das demissões ganhar alguma repercussão, elas receberam 5 mil reais como uma espécie de abono por não terem recebido os "prêmios". Para as trabalhadoras, ainda que tenha sido um alto valor em dinheiro, a humilhação ficaria marcada: "Foi um 'cala a boca' que eles deram", resumiu Juliana.

A responsabilidade socioambiental parece, aqui, ser uma espécie de civilização do operário "bárbaro", sem "modos" e sem os conhecimentos de higiene, asseio e controle. No entanto, este aspecto "socioambiental" é apropriado e mantido na organização do trabalho. Incluído em metas empresariais, como visto no capítulo 1, torna-se parte muito importante do perfil da marca e da atratividade dos produtos da Natura no mercado.

\section{O "modelo da competência", o papel da formação e nova condição operária}

A descrição da Natura sobre suas políticas de contratação e o tipo de discurso possível de captar nas declarações de Richard - que parece estimular nos trabalhadores têm muita relação com a caracterização a respeito do "modelo da competência", uma noção mobilizada a partir dos anos 80 no debate sobre as novas práticas de gestão nas empresas. Susana Diniz fala sobre como, no geral, são realizadas as contratações na fábrica.

"O que a gente faz normalmente é: se aumentou a produção ou tem necessidade de produzir ou de embalar, a gente abre vagas temporárias por três meses. A gente faz o processo seletivo, as pessoas vêm, elas trabalham três meses e a gente daí acompanha desempenho, elas têm o mesmo treinamento de pessoa que tá trabalhando full time na Natura, passam pelo programa de integração, tudo igual. Aí, conforme o desenvolvimento delas e a produção se mantém, ou seja, a necessidade de manter essas pessoas, de emprego, ela existe, aí a gente admite essas pessoas como funcionárias de fato. Se não, a gente termina o período temporário e aí a gente espera ter um novo pico de produção para ver se a gente cresce ou não cresce. (...) A entrevista é muito de comportamento, de conhecimento, de atitude, enfim, de como pode conduzir o trabalho na fábrica. De perfil pessoal mesmo". 
A Natura possui um programa de formação e certificação chamado "Meu Caminho", que "oferece aos trabalhadores a oportunidade de assumirem a responsabilidade pelo próprio desenvolvimento de acordo com aspirações e interesses de aprendizagem, valorizando habilidades e tornando cada um protagonista de sua própria história",55. O programa é composto pela "Avaliação de Aderência à Essência Natura (AAD)", prova teórica e prova técnica. A AAD recebe esse nome "pois contempla os comportamentos valorizados pela cultura da empresa"56. Um dos requisitos do programa é a formação acadêmica (para algumas categorias de trabalhadores, nível médio; para outras, curso técnico; e, para outras, nível superior).

A AAD oferece cinco parâmetros, distribuídos e hierarquizados da seguinte forma: 1 - Necessita aprimorar comportamento; 2 - Comportamento parcialmente dentro do esperado; 3 - Apresenta consistentemente esse comportamento; 4 Comportamento acima do esperado; e 5 - Não consigo avaliar. Com eles, os trabalhadores devem classificar uma série de atos. Ao final, recebem uma pontuação, requerida, por exemplo, para mudanças de faixas salariais ${ }^{57}$. Caso o desempenho na $\mathrm{AAD}$ não seja satisfatório, o trabalhador "terá o acompanhamento do seu gestor direto para entender o que aconteceu e buscar seu desenvolvimento esperado" ${ }^{\text {"58. }}$.

A própria descrição do "Meu Caminho", acima sintetizada, encerra uma contradição muito curiosa do discurso da empresa porque o programa é oferecido como a possibilidade de o trabalhador individualmente assumir a "responsabilidade" por sua carreira, sendo "protagonista de sua própria história". Ao mesmo tempo, porém, existe um "desenvolvimento esperado" em termos de "aderência à essência" - ou seja, aos valores empresariais - cuja desobediência não apenas freia o aumento salarial como requer o acompanhamento direto do superior, para fazer com que o trabalhador obtenha o nível de "aderência" que se espera". Este é um exemplo claro de disciplinarização,

\footnotetext{
55 Conforme descrição presente no caderno distribuído aos trabalhadores da empresa sobre a certificação "Meu Caminho" de 2011.

${ }^{56}$ Idem.

${ }^{57}$ Os trabalhadores, ao final do processo, são enquadrados nas categorias C1 (a pior), C2 e C3 (a melhor). Esta categorização condiciona mudanças de faixa salarial e a possibilidade de promoção, vedada a quem obtém o nível C1.

${ }^{58}$ Conforme caderno de descrição da certificação "Meu Caminho".

${ }^{59}$ Contradição, aliás, que a própria nomenclatura adotada expõe: de um lado, "meu caminho"; de outro, "aderência à essência". Trata-se, então, ao que tudo indica, de um caminho próprio para o trabalhador, desde que na estrada indicada pela gerência.
} 
muito pouco compatível com qualquer viabilidade de "autonomia" em relação ao próprio trabalhador.

Claude Dubar (1999) enumera cinco características a respeito do "modelo da competência": 1) a introdução de "novas normas de recrutamento, que privilegiam o "nível de diploma"”; 2) acompanhamento individualizado da carreira; 3) novos critérios de avaliação, "que não são habilidades manuais, nem conhecimentos técnicos, mas antes qualidades pessoais e relacionais, (...) 'mobilização' em prol da empresa”; 4) formação contínua, "peça-chave nesse 'novo dispositivo da mobilização', que é a formação, frequentemente representada como 'inovadora', criada pela própria empresa em relação estreita com sua estratégia"; e 5) "desabono, direto ou indireto, dos antigos sistemas de classificação, fundados nos 'níveis de qualificação', oriundos das negociações coletivas, e a multiplicação de fórmulas de individualização dos salários" (DUBAR, 1999: 58).

Susana Diniz assim descreve a avaliação de "aderência à Essência" e mostra que, através dela, uma série de "comportamentos" são "requeridos" pela empresa.

“A avaliação de desempenho é feita sempre com 'aderência à Essência' e depois a entrega operacional (...). Eu tenho um rol de perguntas, que são todos os temas ligados a aderência à essência à qual todos são avaliados em 360 [graus]: meus funcionários me avaliam, meus pares, meus clientes, meus chefes. E a partir disso gera uma nota que me posiciona dentro desse conjunto de 'aderência à Essência' e aí então, de volta, todo mês, todo período, você vai fazendo o feedback com seu gestor e ele vai apontando onde está o conceito (...). É como você faz e o que você faz. Isso te gera a possibilidade de ser promovido, ter méritos de salário, dependendo do seu desenvolvimento como você está, níveis maiores, ou menores e ainda o seu plano de desenvolvimento.

(...) Para gente, é importante que as pessoas tenham este alinhamento e que este seja o foco a se buscar. Então, a todo momento, a gente tá botando os conceitos da 'Essência' à prova. O que a gente quer com isso? A gente acredita que estes são 'valores' - eu vou usar o termo 'valores', embora a gente não use - estes são 'valores' com os quais a gente acredita que se faça uma sociedade saudável, sustentável e socialmente responsável. Então, por conta disso, a gente exige que estes comportamentos sejam os mínimos requeridos. Então, de acordo com isso, ela [a trabalhadora ou o trabalhador] tem a possibilidade de ter um ambiente melhor, uma produção mais efetiva, produtiva e de melhor sustentabilidade, tanto ambiental como social. Então, o que se espera é isto. A forma de se fazer e como isto opera no dia-a-dia tem toda essa dinâmica. E a gente vai reforçando a cada instrumento e a cada coisa que a gente faz reforça a 'Essência' o tempo todo: na integração, nos treinamentos, na avaliação, nos feedbacks que eu vou dar do meu desempenho, seja também na pesquisa anual que eu faço para entender como a gente tá de aderência a essa 'Essência' ou não”.

Com efeito, o "modelo de competência" coloca a empresa como o vetor da mobilização dos assalariados e estabelece os critérios identitários, em detrimento de critérios anteriormente válidos. Na medida em que há uma avaliação da carreira crescentemente individualizada e a adoção de formas também individualizadas de 
pagamento, é possível entender uma das causas pelas quais as negociações coletivas podem ver-se fragilizadas, bem como os sindicatos como espaço de formação, socialização e organização dos trabalhadores. Dubar chega a afirmar a existência, nesses marcos, de uma verdadeira "identidade de empresa". Não deixa de ser tentador, nesse momento, refletir novamente sobre o significado da camiseta bordada de Richard.

Parece evidente que mobilizar o grupo de trabalhadores, dando-lhe coesão ao redor de valores empresariais cuja aceitação e prática são requeridos permanentemente, traz contrapartidas econômicas e ganho de produtividade. Ao ser questionada a respeito, Susana Diniz, apesar de tangenciar o tema por meio de uma série de jargões de Recursos Humanos, acaba admitindo-o:

“A gente criou o 'Meu Caminho', que é, dentro da escala de salários, dentro da estrutura e de funções da fábrica, trilhas de desenvolvimento em que as pessoas vão se posicionando para que elas possam se desenvolver criando novas expertises. Então, com isso, o 'Meu Caminho' vai dando a opção de você se desenvolver e de estar pronto para novas funções, para ser promovido... Além disso, a gente põe um bloco de questões que estão ligadas a seu autodesenvolvimento, que têm a ver com a nossa 'essência'. Além disso, a gente coloca questões ligadas a empreendedorismo e cidadania, sustentabilidade e cidadania. Então, são basicamente quatro grandes trilhas que são montam esses programas, algumas que são funcionais, efetivas, para fazer exercício da função e outras que vão complementando esse desenvolvimento no processo de crescimento. E o que a gente coloca para esse grupo é que quanto mais eles forem caminhando nesses programas, como incentivo ali, eles vão ganhando um salário maior, que é uma forma de fomentar e desenvolver estas pessoas com o objetivo de se desenvolver, apesar de que às vezes a... Vamos dizer assim, o objetivo inicial não seja o melhor [fala dando uma leve risada], que seja a busca de um salário, mas que com o tempo eles percebem que eles estão melhores pessoas, enfim, que a educação faz diferença".

[Thiago Aguiar] Isto tudo parece muito interessante, mas eu imagino que deva ter uma contrapartida econômica para a empresa. Imagino que a produtividade de alguém que passe por uma experiência desse tipo seja superior a...

[Denise Asnis] “[Interrompendo a pergunta enfaticamente] Claro! Claro! É assim: não dá para se medir, é uma crença. Por que as empresas investem em educação? É uma crença. Você não consegue medir se uma empresa que investe em educação é mais produtiva ou menos produtiva que a outra que não investe, né? (...) Enfim, quando eu entrei na organização, o presidente me fez uma pergunta: 'por que eu tenho que te contratar?'. Eu tentei responder e ele falou assim: 'por que eu tenho que manter uma área de treinamento? Se eu pegar o valor que eu tenho hoje e distribuir cerca de R\$ 3 mil para cada um dos colaboradores deve ser o valor que eu gasto em educação. Por que é melhor eu ter a área e não fazer isto?' E, aí, o que eu respondi - e é o que eu acredito até hoje sobre isto - é que, quando você faz este movimento, você desperta nas pessoas a possibilidade de ela abranger coisas que ela não estava acostumada e nem dava valor (...). Então você mostra um mundo ao qual às vezes ela não estava conectada. A segunda questão é que você começa a olhar a organização a médio e longo prazo porque se hoje te der o dinheiro você vai usar o dinheiro no seu curso ou numa coisa qualquer e você amanhã já botou ela no seu salário. Esse dinheiro já foi. E você não garante o desenvolvimento da organização para o futuro. Você não garante que estas pessoas vão se desenvolver exatamente nas questões que estão ligadas ao processo da empresa, aquilo que a empresa acredita. Então, dado isto, é melhor para mim você ter uma formação interna e poder apoiar este desenvolvimento 'teleguiado' - vamos assim 
dizer - porque, no fundo, ela mantém a sustentabilidade formal, mesmo de grana, da empresa em pé. E isto por conta, obviamente, de produtividade, de conhecimento e tal (...). Então, é óbvio que a organização está sempre objetivando que tenha um resultado melhor. Não resta a menor dúvida".

O caso das trabalhadoras lesionadas demitidas é um drama concreto, mas bastante representativo das consequências do "modelo da competência". Aquelas trabalhadoras, apesar dos e também pelos muitos anos na empresa, já não tinham condições de oferecer o que se lhes demandava: agilidade, destreza, alta produtividade, estímulo individual com as metas propostas e, por essa via, "aderência à essência". A justificativa de que elas não tinham "comprometimento" - absurda ao se levar em conta suas histórias de sofrimento individual - "faz sentido" se avaliada pela ótica das expectativas da empresa com relação aos “colaboradores". É necessário engajamento total. As demissões demonstram que aqueles que não puderem oferecer isto, pela idade mais avançada, pela incapacidade de lidar com novas máquinas e as novas formas propostas de organização da produção, do trabalho e da remuneração, não terão lugar na empresa. Quando as trabalhadoras lesionadas sublinhavam a dimensão "exemplar" de sua demissões, era exatamente a isto que se referiam.

Mas o fato de que sejam mulheres a maior parte das que compunham o grupo de lesionadas demitidas, e agora indesejadas, pela empresa talvez requeira um olhar mais atento, afinal

\footnotetext{
"Esta demissão não foi um caso isolado. A empresa vem ano a ano, mês a mês demitindo pessoas lesionadas. Uma amostragem dos atendimentos realizados pelo médico do trabalho, dos quais $75 \%$ são mulheres, mostrou que a doença ocupacional que mais atinge os funcionários da Natura é a LER/DORT. Cerca de $30 \%$ já sofreram algum tipo de cirurgia realizada em função de questões ergonômicas. Apenas um caso de cirurgia foi ocasionado por acidente mecânico (um trabalhador atropelado por empilhadeira). Dos 98 casos constantes da amostra, metade havia sido demitida com sequelas" (Carta-denúncia do Sindicato dos Químicos Unificados à Câmara dos Deputados, p. 2.).
}

\section{Qualificação, competência e divisão sexual do trabalho como parte da "nova condição operária": uma breve discussão}

No debate a respeito do "novo modelo produtivo", de onde emergiu a caracterização do "modelo da competência", considerou-se superada a perspectiva de Braverman (1983) sobre a desqualificação gradual e progressiva do trabalho. Na verdade, como alguns argumentaram, poderia estar em andamento um processo de "requalificação" dos trabalhadores, através das possibilidades de polivalência, 
autonomia e aprendizado de novas técnicas. Para Hirata (1994), no entanto, esta é uma abordagem limitada do fenômeno na medida em que exclui da análise o fato de que boa parte das trabalhadoras de sexo feminino e de trabalhadores de empresas subcontratadas, por exemplo, não vivenciam a "requalificação". Tal caracterização, que está por trás do "modelo da competência" considera o trabalhador homem como encarnando o trabalhador universal. Além disso, Hirata argumenta que a noção de “competência", já em sua origem, carrega uma forte conotação ideológica e de discurso empresarial. Ela remete a um sujeito e a uma subjetividade e leva em consideração uma dimensão de "saber-ser". A introdução, na análise, da divisão sexual e internacional do trabalho, mostra que, na verdade, houve descontinuidades em "ilhas de modernidade" com sofisticação tecnológica e organizacional, mas também coexistência com práticas e métodos tayloristas, visíveis particularmente em empresas instaladas em países subdesenvolvidos e nos ramos femininos de atividade. Revela-se, assim, a insuficiência das teorias em torno da "requalificação".

Uma das características marcantes do trabalho feminino, sobre as quais, ao longo das últimas décadas, as feministas se debruçaram, é a instrumentalização de qualificações, habilidades e atitudes "invisíveis", consideradas "naturalmente" femininas. Analisando trabalhadoras em indústrias em países subdesenvolvidos, Elson e Pearson (1999) mostraram a relação entre a divisão sexual do trabalho e custos mais baixos de produção, com consequente aumento da produtividade e dos lucros. As habilidades femininas, muitas das quais aprendidas na socialização familiar e no trabalho doméstico, não remunerado, são apropriadas na fábrica, os "dedos ágeis" das mulheres as tornam "trabalhadoras baratas", submetidas a trabalhos repetitivos e que possuem um status inferior enquanto trabalhadoras por conta das visões do trabalho feminino como complemento da renda familiar e conciliação com o trabalho doméstico.

Com a globalização, no entanto, tais questões podem ser recolocadas. Hirata (2009) abordou as consequências paradoxais da globalização sobre o trabalho feminino. A bipolarização é uma delas - de um lado, a consolidação da presença feminina em algumas áreas de prestígio e maior remuneração; de outro, porém, há uma presença feminina em grande escala em atividades mal remuneradas e precárias. Há uma espécie de "divisão sexuada da precariedade". Por outro lado, um novo fenômeno ganhou vulto com o aumento das migrações internacionais relacionadas ao trabalho de cuidado (care). Muitas mães, por exemplo, em países desenvolvidos, passaram a contratar trabalhadoras 
imigrantes para os serviços domésticos e para o cuidado de seus filhos e idosos. Tais atividades, quando realizadas no âmbito familiar, eram tidas como "naturalmente" de responsabilidade feminina na família e, com a ausência de remuneração, as qualificações para elas exigidas permaneciam invisíveis.

O trabalho de cuidado (care), como sublinham Molinier (2008) e Soares (2012) lida com uma série de qualificações vistas como "naturalmente" femininas - a "compaixão", segundo a primeira autora, ou aquelas relacionadas ao "trabalho emocional", de acordo com o segundo. Nesse tipo de atividade, surge um paradoxo, cujo debate é útil para as reflexões sobre trabalho e gênero: a dimensão emocional do trabalho, apesar de não ser parte das prescrições técnicas das atividades, é, ao mesmo tempo, um requisito fundamental para a consecução das atividades de cuidado.

Desse modo, tanto o aumento das migrações internacionais relacionadas ao care - com a crescente remuneração de atividades antes circunscritas ao âmbito doméstico como a dimensão emocional, não prescrita, mas necessária para a realização destas tarefas, permitem o questionamento de uma visão, ainda fortemente enraizada na sociedade e por óbvio no trabalho, de que existem certas características "natural" e eminentemente femininas.

É possível, então, refletir a falta de "comprometimento" e a demissão das trabalhadoras lesionadas da Natura como a demonstração de como são requeridas tais qualificações sociais invisibilizadas no trabalho feminino. Mesmo numa fábrica "moderna", que adota tecnologia e formas de organização da produção consoantes com o que de mais avançado se adota em outros países, parte significativa da produtividade e da competitividade internacional da empresa está assentada em sua capacidade de intensificar o ritmo de produção. As trabalhadoras demitidas perderam, em decorrência das doenças do trabalho a que estavam acometidas, justamente alguns dos quesitos "naturalmente" femininos mais valorizados: a agilidade, a capacidade de realizar tarefas repetitivas, e mesmo a propensão ao "jogo de cintura" e à passividade, haja vista sua procura por afastamento, tratamento e mesmo a resistência, da forma que lhes era 
possível, ao modo como a empresa ${ }^{60}$ lidou com seu caso. Aquelas trabalhadoras demonstravam não ser mais capazes de mostar sua "aderência à essência" empresarial.

No debate a respeito de uma "nova condição operária" pós-fordista, fica clara, dessa forma, a necessidade de introduzir na análise a divisão sexual do trabalho, que possibilita compreender elementos de continuidade num processo de profundas transformações do trabalho.

Neste capítulo, buscou-se apresentar algumas reflexões sobre as contrapartidas sociológicas das mudanças na organização da produção e do trabalho em andamento nas últimas décadas. As demissões de trabalhadoras lesionadas, a nosso juízo, contribuem no entendimento do processo de reestruturação das empresas, que carrega consigo a desestruturação de um antigo grupo operário e a ascensão de um novo grupo. Levar em conta uma abordagem de gênero joga luz a uma dimensão de desestruturação também sexuada de uma antiga coletividade operária e a consequente ascensão de um novo grupo, sobre o qual a divisão sexual do trabalho, no entanto, segue operando. As questões discutidas nas páginas precedentes sobre as demissões na Natura parecem indicar pistas importantes a respeito.

Talvez se esteja diante de uma espécie de paradoxo do "comprometimento", exigido pela empresa flexível: de um lado estão o novo modelo produtivo e o discurso de empresa "moderna", que busca o "comprometimento" com certos valores, a participação e o engajamento dos trabalhadores; de outro, porém, aparece o "comprometimento" significando a dedicação integral às atividades produtivas, intensificadas e repetitivas para dar conta das metas empresariais.

No discurso empresarial, o primeiro aspecto do "comprometimento" é valorizado e com ele pretende-se encontrar formas de obscurecer o segundo aspecto, a necessidade, por parte do trabalhador, de lidar com a intensificação crescente e aceitála. Buscar de diversas formas a "opacidade do trabalho" em meio a um discurso de "transparência" empresarial permanente parece ser a principal estratégia da Natura, como se abordará novamente nas conclusões deste trabalho, para lidar com esta espécie de paradoxo do "comprometimento" aqui apontado. Pode-se dizer, então, que há

\footnotetext{
${ }^{60}$ Relembrem-se, por exemplo, as tentativas de líderes e mesmo de alguns trabalhadores de desmoralizar e ridicularizar as trabalhadoras por terem aparecido no jornal do sindicato e, especialmente, após terem ido, audaciosamente, a Brasília.
} 
elementos de descontinuidade, mas, sem dúvida, também de persistência na "nova condição operária"61. As descontinuidades parecem localizar-se em maior medida, como se viu, no âmbito da consciência e da organização operárias.

${ }^{61}$ Beaud e Pialoux (2009), aliás, alertaram para a intensificação do trabalho na Peugeot-Sochaux no período pós-reestruturação. As "contradições do jovem monitor" retratam exatamente este descompasso entre as expectativas geradas pelo discurso empresarial e a realidade da intensificação das tarefas e do trabalho no âmbito da produção. 


\section{Capítulo 4 - O sociólogo em uma "guerrilha simbólica": a "identificação de propósitos" entre a empresa global e seu fundador bilionário}

“É uma essência de erva doce, o perfume que o senhor Luiz Seabra, fundador da Natura, por muito tempo quis produzir em sua juventude. Um vaporizador faz com que a essência receba todos os visitantes da fábrica na recepção". Assim respondeu Walter, guia das visitas à fábrica da Natura em Cajamar, ao questionamento, surgido da surpresa: a recepção em Cajamar não parece propriamente a imagem de uma fábrica. Amplo espaço, balcão de madeira, iluminação solar, vasos de plantas. O cenário limpo, clean, completa-se com uma espécie de sala de estar. Na parede ao fundo, um anúncio de uma nova fragrância. No canto, um totem eletrônico convida o visitante a conhecer mais da empresa através de um software acionado por toque em tela, "Natura memória viva: Natura de A a Z". A mente, no entanto, fixa logo na entrada a marcante essência de erva doce, percebida no mesmo momento em que se lê um grande painel, que traz a outra "essência" da empresa:

"Nossa razão de ser é criar e comercializar

produtos e serviços que promovam o bem-estar

estar-bem"

A resposta do guia de visitas chamou a atenção. Luiz Seabra parece estar presente em inúmeros detalhes da empresa que fundou. Semanas antes, num imponente, mas discreto edifício na região empresarial da Avenida Brigadeiro Faria Lima, no Itaim Bibi, em São Paulo, foi possível entrevistá-lo. O edifício é sede de importantes fundos de participação como Votorantim Participações (do empresário Antônio Ermírio de Moraes) e Gávea (cujo acionista mais notório é o ex-presidente do Banco Central Armínio Fraga). Somente ao chegar ao local, foi possível perceber que se tratava não de um escritório da Natura, senão do Janus, o fundo de participações controlado pelos três copresidentes da Natura (Luiz Seabra, Guilherme Leal e Pedro Passos) e que administra seus negócios e investimentos. Localizado na região paulistana onde se concentram na atualidade as principais sedes de bancos, corretoras e empresas que atuam no mercado financeiro, o tamanho do edifício e as empresas que abriga contrastam com a aparente 
tranquilidade de sua recepção. Apesar de ampla e luxuosa, aspectos somente possíveis de distinguir de dentro, não contava com um enorme aparato de segurança visível, como seria possível imaginar. Apenas um guarda acompanhava à distância os visitantes que entravam e retiravam seus crachás.

A inesperada entrevista com Luiz Seabra ocorreu após meses de difícil tentativa de entrada em campo e foi um fruto do acaso ${ }^{62}$. Tendo já sido realizados diversos contatos e entrevistas com o grupo de trabalhadoras lesionadas demitidas, foi possível, por intermédio delas, conhecer e realizar entrevistas com alguns trabalhadores de Cajamar. No entanto, a entrada na fábrica ainda constituía um grande desafio de pesquisa, do qual dependia o contato com outros trabalhadores e com a gerência da Natura. Durante cerca de 1 ano, fracassaram as tentativas de agendar uma entrevista com a empresa, especialmente através da área de Recursos Humanos, por meio de diferentes interlocutores sugeridos por diretores do Sindicato dos Químicos. A maioria das respostas dizia que o pedido seria encaminhado para pessoa apta a receber o pesquisador e responder às perguntas, mas apesar das insistentes tentativas, nunca se obtinha uma resposta definitiva para as solicitações de entrevista ou de visita à fábrica.

Com efeito, a realização da entrevista com Seabra não foi apenas importante em si, já que, a partir dela, pôde-se avançar na estratégia de pesquisa e de entrada em campo, superando as dificuldades iniciais. Por meio de Seabra e de sua secretária, após a entrevista, foi possível conseguir agendar a primeira visita à fábrica e entrevistas com gerentes e com a área de RH de Natura. Com isto, abriu-se a possibilidade de acesso à fábrica e, então, de conhecer e entrevistar trabalhadores da empresa.

Se, por um lado, as entrevistas com trabalhadores e pessoal de enquadramento da empresa, e a análise de dados e materiais corporativos permitem lançar luz ao que se está considerando uma "nova condição operária" numa empresa global de capital

\footnotetext{
${ }^{62}$ Quando as dificuldades de entrada em campo começavam a preocupar de modo mais intenso, eis que numa conversa informal com pessoa do círculo familiar deste pesquisador, entre perguntas despretensiosas sobre a pesquisa em andamento, surgiu a informação: Luiz Seabra, quando jovem, trabalhara com esta pessoa na Remington Rand muitos anos antes de tornar-se empresário, no período entre o final dos anos 50 e o começo dos anos 60, quando ele ainda era ajudante no departamento pessoal daquela empresa. $\mathrm{O}$ contato entre os antigos colegas de trabalho de juventude, perdido por mais de 40 anos, foi retomado numa situação igualmente inesperada: trabalhava na organização de um evento onde estava o empresário Seabra uma amiga de sua antiga colega de Remington, que lhe falou a respeito disto. Desde então, Seabra passou a manter contato telefônico eventual com ela, especialmente em datas comemorativas como o Natal. Ao saber desta curiosa e bem-vinda coincidência, pedi que ela me ajudasse a solicitar uma entrevista com Seabra, o que se viabilizou semanas depois, através do contato que por meio dela obtive da secretária particular de Seabra no fundo Janus.
} 
nacional - a Natura -, por outro, a entrevista com Luiz Seabra é reveladora de um aspecto fundamental de tal processo: a construção do discurso empresarial que alimenta e justifica as práticas da empresa "moderna". Nele, o trabalho concreto de milhares de operários, fundamental para que a empresa mantenha sua robusta dimensão econômica, parece sair de cena. Na voz do fundador da companhia, as atividades produtivas têm papel coadjuvante face às novas questões como a valorização da "responsabilidade ambiental", a "essência" humanista da atividade empresarial e a busca pelo "bem estar". Tal como se pôde observar na organização espacial da fábrica, há, também no discurso empresarial, uma certa opacidade do trabalho em meio à "transparência" pregada pelo fundador da companhia.

A entrevista, além disso, mostrou a permanente presença de referenciais acadêmicos no discurso do fundador da empresa. Reflexões sobre autores de Filosofia e Sociologia acompanharam a narrativa sobre a fundação da empresa e seu crescimento, trazendo a impressão, pouco a pouco, de que Seabra tentava movimentar-se no campo do entrevistador, mobilizando suas ferramentas e recursos. Uma curiosa situação de entrevista, às vezes assemelhada a um jogo de xadrez, às vezes a um enfrentamento tácito e subterrâneo de posições, cujo objetivo parecia ser a defesa "refinada" de uma doxa (BOURDIEU, 2011) empresarial.

O objetivo do capítulo, portanto, será reconstruir a entrevista e a situação na qual se desenvolveu para abordar a produção do discurso empresarial e suas consequências concretas vistas na opacidade do trabalho presente na empresa, além de problematizar por que, na entrevista, parecia estar em curso uma espécie de "guerrilha simbólica" entre sociólogo e empresário.

\section{A entrevista e o(s) ambiente(s)}

O escritório do fundo Janus ocupa dois andares interconectados internamente. A entrada se dá pelo andar inferior. Uma grande porta eletrônica de vidro permite entrar no hall, bastante amplo. De um lado, uma pequena "cachoeira" artificial dá a impressão de tranquilidade e de proximidade com a natureza. O hall termina, sem paredes, numa área de escritórios. Pinturas em verde no hall e a área de escritórios, branquíssima, sugerem amplitude do espaço e limpeza. No meio do andar inferior, o balcão das 
secretárias é feito de madeira rústica e vidro. Como mesas de centro, há duas grandes seções de tronco de árvore. Em conjunto com o piso de granito rústico, completando a decoração do hall, todo o ambiente deixa a impressão de uma limpíssima, moderna e pequena "floresta", uma espécie de cartão de visitas sustentável que talvez faça esquecer, por alguns instantes, ser ali a sede de um bilionário fundo brasileiro de capitais.

O tempo de espera para entrevista foi de cerca de quinze minutos. No sofá, era possível ver, sobre cada um dos troncos, cartões de certificação daquela madeira, comprovando sua origem e manejo, com "responsabilidade ambiental", além de materiais corporativos da Natura. Acompanham-nos uma revista chamada "Mulheres da Amazônia", além de outra sobre empresas com "boas práticas em gestão ambiental" e vasos de vidro com grandes flores tropicais. Entre as salas e escritórios, outras mesas com vasos e publicações do mesmo tipo compõem o cenário.

Luiz Seabra fundou a Natura em 1969. Com 71 anos, figura nos rankings internacionais de maiores fortunas do planeta. Segundo a lista da Forbes ${ }^{63}$ divulgada em março de 2013, Seabra possui um patrimônio de 3,2 bilhões de dólares, ocupando a $423^{\mathrm{a}}$ posição entre os mais ricos do mundo, empatado com o diretor de cinema Steven Spielberg e com o bilionário estadunidense Donald Trump. Em posições inferiores na lista, estão, por exemplo, Oprah Winfrey, apresentadora multimilionária da televisão estadunidense, e David Rockefeller Sr., herdeiro da tradicional família Rockefeller. Entre os bilionários brasileiros, Seabra ocupa a 14 posição, logo atrás de Abílio Diniz, cuja fortuna é de 3,7 bilhões de dólares e à frente, entre outros, de Moise Safra (2,4 bi), de seu sócio na Natura Guilherme Leal (1,8 bi), de Alfredo Egydio Arruda Vilela Filho (1,15 bi), do banco Itaú e do apresentador de televisão, dono do SBT e hoje concorrente de Seabra na área de cosméticos, Silvio Santos (1,3 bi).

A sala de Luiz Seabra, localizada no andar superior da sede do fundo Janus, é grande e suntuosa, sem no entanto ser de luxo ostentatório. Logo na entrada, há um sofá e uma mesa de centro, com publicações de mesmo tipo das encontradas no hall. Ao fundo, há uma ampla mesa, ladeada por estantes que compõem uma pequena biblioteca, a qual o entrevistado faz questão de mostrar logo no início da entrevista. Um garçom,

\footnotetext{
${ }^{63}$ http://www.forbes.com/profile/antonio-luiz-seabra.
} 
com os tradicionais fraque branco, calças pretas e gravata borboleta, circula permanentemente, oferecendo água, chás, café e sucos de diversos tipos de frutas.

\section{Filosofia e "refinamento": a "essência" da Natura e seu fundador}

Seabra é bastante receptivo. Aceita que a entrevista seja gravada, mas pede que conversemos um pouco antes sem gravar para, segundo diz, "quebrar o gelo". Logo no início, pergunta a respeito de minha formação e dos motivos por ter escolhido a Sociologia como área de atuação. Interessa-se por meus sociólogos diletos e me apresenta parte de sua biblioteca. Ali, segundo ele, há livros de um sociólogo alemão que eu não conhecia. Os de Bourdieu, por outro lado, não estavam ali: "Em casa, tenho alguns dele". Logo, pergunta o que eu achava da teoria do "homem cordial", de Sérgio Buarque de Holanda (1995). "Sempre me interessei por esta caracterização do homem brasileiro e do homem latino", afirma, explicando que o caráter passional pode ser uma virtude do brasileiro nos negócios. Pondero, no entanto, que existe uma dupla dimensão no "homem cordial" e que, se por um lado, há o elemento de proximidade e aversão ao formal, por outro pode haver um elemento também passional, mas colérico ou mesmo vingativo, que a informalidade "cordial" traz consigo e que pode trazer dificuldades do ponto de vista dos negócios. "Nunca tinha visto a questão por este lado. Interessante", responde.

O surpreendente debate sobre Ciências Sociais e Filosofia - que logo Seabra revela ser um de seus maiores interesses -, em que apareceram personagens tão distintos como Gilberto Freyre, Platão, Roberto DaMatta, Montaigne, Florestan Fernandes ou Max Weber, mostrou logo no primeiro momento uma das características que o fundador da Natura faz questão de revelar: a busca por "refinamento" intelectual. Um entrevistado que tenta mover-se no mesmo campo em que está o pesquisador. Conduzir a entrevista nestas circunstâncias é um desafio adicional, uma tensão simbólica permanente.

Para Pierre Bourdieu (2007), a produção da ciência depende da preservação da autonomia do campo científico frente à interferência de forças externas, como o mercado e o Estado, que podem perverter o conhecimento elaborado na universidade, seu lugar de excelência. Michael Burawoy (2010), numa abordagem crítica ao que ele 
considera serem os "paradoxos" de tal autonomia, reconstrói os argumentos de Bourdieu e relembra que o sociólogo francês, nas Meditações Pascalianas (2007), "compara a competição no campo científico com os combates de guerrilha" (BURAWOY, 2010, p. 38) nos quais se trata de uma disputa pela concentração de um capital específico daquele campo. Ora, evidentemente, a entrevista com Seabra não se tratava de um debate acadêmico no interior da Sociologia. No entanto, com efeito, o diálogo ocorrido sem gravação, "para quebrar o gelo", se assemelhou em muitos momentos a um "teste" aplicado pelo entrevistado, a uma tentativa de mostrar-se em condições iguais ou superiores de manejar conceitos de Sociologia e Filosofia, de mobilizar leituras pouco acessíveis a leigos. Estava em curso uma espécie de "guerrilha simbólica”, que permaneceu durante todo o período de interação.

Durante a entrevista, o empresário apresenta seu círculo de relações. Logo no início, fala sobre um recente debate que tem mantido com o economista, ex-presidente do BNDES, André Lara Resende - seu vizinho, como contou, num condomínio no Morumbi e no próprio conjunto empresarial próximo à Faria Lima - no qual este defende o pessimismo e Seabra o ceticismo, influenciado por Montaigne. Em outro momento, Guilherme Leal, seu sócio na Natura e no fundo Janus, candidato a vicepresidente na chapa de Marina Silva em 2010, passa em frente à sala. "Oi, seu Gui! Daqui a pouquinho eu te vejo!", saúda Seabra. Pouco depois, por telefone, alerta sua secretária de que irá acompanhado por outro executivo da empresa numa viagem de helicóptero que faria durante a tarde.

O "refinamento" de Seabra é uma característica presente também em suas declarações para a imprensa. Em entrevista à "Época Negócios", revista voltada ao público empresarial, as informações sobre sua empresa aparecem mescladas com debates a respeito do humanismo e com a apresentação dos cerca de 50 livros que ele havia comprado naquele ano (2012). "Deveríamos pensar em nossas companhias não

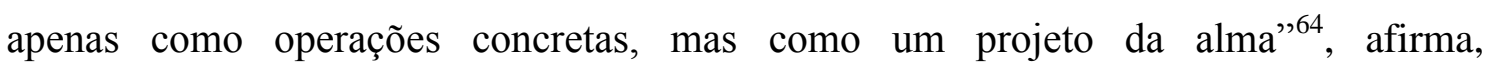
sintetizando sua visão sobre o desenvolvimento da companhia que fundou e que hoje lidera o mercado de cosméticos no país.

\footnotetext{
64 “Época Négocios”, Editora Globo. Dezembro de 2012. p. 83.
} 
Na mesma direção, o empresário se move nas declarações a uma revista, edição especial do Le Monde sobre o Brasil ${ }^{65}$ que circulou na França em 2010. "Leve esta revista. Pode ser interessante para sua pesquisa", diz Seabra. Na entrevista concedida ao veículo francês, fala sobre sua trajetória empresarial, a filosofia "como princípio de vida" e sobre a Natura como uma empresa que escolheu outra forma de administrar seus negócios, respeitando o desenvolvimento sustentável.

Desse modo, durante o período da entrevista no escritório do Itaim Bibi, Seabra parecia revelar suas "credenciais": por um lado, apesar do ambiente deixá-lo à vontade, o empresário não transparecia qualquer interesse em mostrar-se como um bilionário ${ }^{66}$; ao contrário, mostrava simplicidade em sua forma de direcionar-se ao entrevistador; por outro, porém, Seabra parecia querer mostrar seu refinamento intelectual e seus conhecimentos na área do pesquisador que lhe entrevistava. O fundador da Natura mostrava que também acumulava o capital próprio do campo específico no qual o sociólogo está inserido. Seabra, com sua biblioteca, livros e citações gritava em voz baixa e calma ser portador de "capital cultural", além do "capital social" revelado por suas múltiplas relações e, como consequência, "capital simbólico" - ou os efeitos simbólicos do acúmulo de capital (BOURDIEU, 2007).

Como um perfume de erva doce, a "essência" da empresa, na voz de seu fundador, parece etérea, fruto de lances geniais, de uma concepção a respeito de "si e do outro" e de uma nova "linguagem" para os cosméticos. Seabra apresenta sua história individual confundida com a história da empresa. Em ambas, o crescimento se dá como que através da genialidade do fundador, de sua visão e capacidade excepcional como empresário, que se revelou desde os primeiros anos como "missão". Característica também visível segundo sua descrição da organização da fábrica de Cajamar, onde reinaria a "transparência", e na própria maneira como a Natura organiza o discurso empresarial sobre o trabalho: as "operações concretas", produtivas, parecem sair de cena. A gestão do trabalho de milhares de operários e sua produtividade aparecem como coadjuvantes na reconstrução da história da formação e da expansão da gigante brasileira dos cosméticos, conduzida por seu fundador e principal acionista, hoje uma empresa global.

\footnotetext{
65 “Brésil, um géant s’impose”. Le Monde - Hors-série. 2010. p. 59.

${ }^{66}$ De qualquer maneira, obviamente, é preciso questionar-se se seria necessário algo além do próprio ambiente da entrevista e de sua já conhecida história como empresário para que Seabra se mostrasse como possuidor de uma grande monta de capital econômico. Não parece ser o caso.
} 
Até aqui a tentativa foi de afirmar que Seabra, um empresário bem-sucedido e portanto no topo das posições possíveis no campo econômico, busca mostrar seu acúmulo também de "capital cultural". Além disso, o discurso empresarial da Natura e a trajetória de seu fundador parecem fundir-se, pregando uma transparência que é opaca do ponto de vista do trabalho. Seria possível abordar a narrativa do empresário de um ponto de vista factual, jornalístico. Porém, para avaliar de um ponto de vista sociológico as estratégias empresariais enunciadas pelo fundador da companhia e problematizar a inesperada "guerrilha simbólica" desenvolvida com seu entrevistador, é preciso tratar da trajetória pessoal e empresarial de Seabra. É interessante, portanto, recorrer à noção de habitus desenvolvida por Bourdieu (2011). O habitus é um sistema de disposições duráveis e transferíveis, estruturado e estruturante, de percepções, pensamentos e ações. Através do habitus, o indivíduo interioriza as condições objetivas às quais está submetido e adquire um sentido do mundo social e das distâncias sociais que deve respeitar. O habitus não é imutável. Ao longo da vida, o indivíduo pode adquirir novas disposições, mas carregará, segundo Bourdieu, as marcas de tal esforço. O que se pretende, a seguir, é seguir estas trilhas.

\section{Os primeiros anos}

Luiz Seabra nasceu em 1942. Filho de uma família modesta que vivia no bairro da Casa Verde, em São Paulo, aos 14 anos começou a trabalhar para ajudar a família na empresa onde seu pai trabalhava como almoxarife.

"Era uma indústria gráfica. Trabalhei lá um ano. Como eu era bom aluno, acharam que eu faria contas direitinho, então me colocaram no setor de custo industrial. Era uma atividade [que] tinha uma sobrecarga muito grande, pelo menos naquele período. Eu era um dos poucos funcionários que tinham que trabalhar em horas extras, feriados, etc., fazendo apropriação, custo de mão-de-obra. Passado um ano, eu queria outras oportunidades. Uma colega de trabalho sugeriu a empresa onde trabalhava o sobrinho dela, que era a Remington Rand."

O período em que trabalhou na Remington Rand, empresa estadunidense que fabricava de produtos eletrônicos a revólveres, é apontado por Seabra como de enorme aprendizado. Tendo iniciado sua carreira na empresa como ajudante no departamento pessoal, algum tempo depois assumiu a chefia do setor. Posteriormente, assumiu a chefia da superintendência da divisão de barbeadores elétricos, um departamento à parte 
naquela companhia. Sua rápida ascensão é creditada, por Seabra, a sua intensa dedicação ao trabalho, que, nos primeiros tempos, impediu inclusive que ele pudesse dar prosseguimento à vida escolar e universitária.

\begin{abstract}
"Aprendi muito naquela empresa, me deu bases, alicerces de vida profissional. A minha formação acadêmica era bastante modesta. Eu vinha de um bairro, a Casa Verde. (...) No curso médio, eu fiz técnico em contabilidade. Quando me formei, não fui para a universidade imediatamente. Nas famílias modestas daquela época, você ser contador já era tudo de bom. Era já suficiente. (...) Como eu tive uma carreira que prosperou - para o senso comum - prosperou muito bem na Remington, aquelas responsabilidades profissionais foram me tomando muito, eu me dediquei, e só fui fazer faculdade de economia muitos anos depois, quando já estava nascendo meu terceiro filho".
\end{abstract}

A formação acadêmica tardia de Seabra e a posse de um diploma universitário não são objetos de grande atenção na narrativa que ele faz de sua trajetória. Ao contrário, ele menciona-as de passagem, como um fato de importância menor em relação a sua rápida ascensão profissional na Remington Rand, que posteriormente lhe permitiu, como se verá, entrar no ramo dos cosméticos e se tornar um empresário de sucesso, quase como "um homem que se fez". Isto chama a atenção porque mostra como os conhecimentos do empresário em Filosofia e Ciências Sociais, mencionados durante toda a entrevista, mas também em suas declarações à imprensa, o capital cultural que ele se esforça por mostrar que adquiriu, não foram obtidos na universidade. Desse modo, falar a respeito das dezenas de livros lidas num determinado ano ou discutir conceitos e autores de Sociologia com seu entrevistador são a maneira de mostrar que não há descompasso entre o acúmulo de capital econômico do empresário bilionário e o capital cultural cuja posse teria sido decisiva para que ele pudesse, inclusive, ser um empresário inovador em sua área.

Aos 24 anos, porém, Seabra enfrenta um dilema em sua carreira na Remington. Por conta de problemas na fábrica de barbeadores da empresa, localizada na Argentina, as operações do departamento que ele chefiava foram encerradas. Ele recebeu a proposta de retornar ao departamento pessoal, mas a recusou. Procurando nova oportunidade de trabalho, acaba conhecendo Pierre Berjeaut, um esteticista francês que mantinha um instituto famoso à época na Rua Haddock Lobo. Este encontro mudaria para sempre sua vida.

Pierre Berjeaut mantinha um pequeno laboratório para suprir com produtos cosméticos as atividades de seu instituto. Para gerenciar suas atividades, Seabra foi 
contratado. "Gerenciar tecnicamente", como ele diz, já que não tinha nenhuma formação ou experiência na área de cosméticos. Com efeito, o futuro fundador da Natura diz que à época tinha preconceito com a atividade, considerando-a "coisa de menina”. No entanto, com o tempo, Berjeaut começa a consultá-lo a respeito do lançamento de novos produtos e Seabra vai adquirindo interesse crescente pela atividade.

"Eu comecei a intuir que tinha uma linguagem que me interessava muito. Uma linguagem da função, quase que da função social do cosmético (...). Porque o cosmético tem uma função social na medida em que ele, conseguindo ser um instrumento de bem estar - foi esta a concepção que começou a nascer para mim naquele período - ele mune as pessoas, as clientes, os clientes, de uma autoconfiança, de um possível reforço de autoestima, que os prepara melhor para o convívio social. Foi com este tipo de intuição que eu comecei a me interessar e a pensar em como os produtos eram compostos, qual era a finalidade de cada uma das matérias-primas e comecei a usar os produtos. E, justamente usando, foi se articulando esta percepção de que, antes de serem produtos para as meninas, para a mulher, e ser ligados a uma questão de futilidade, de vaidade superficial, eu via a possibilidade de um melhor diálogo, de uma melhor aproximação entre mente e corpo, sendo o cosmético uma ponte, tendo ele uma função de ser um instrumento desta proximidade, desta maior intimidade - que implica inclusive numa certa introspecção - entre mente e corpo. E podendo advir daí - esta formulação não estava pronta, mas era a intuição que eu tinha - uma melhor relação do indivíduo consigo próprio, uma melhor aceitação do indivíduo consigo próprio, independente que seja mulher ou homem".

A formulação "Bem estar bem" da Natura seria então mais do que um slogan publicitário. Para Seabra, a área de cosméticos era então povoada por uma "estereotipia desconcertante". Um produto da época, em particular, chamou-lhe a atenção: chamavase "Eterna 27" e propunha a quem o utilizasse manter ou retornar à aparência dos 27 anos. Foi um momento no qual Seabra diz ter buscado uma "nova linguagem" para os cosméticos, já que o mercado estava povoado por "uma imoralidade, um descompromisso com a lógica e com a racionalidade". Era necessário, segundo ele, buscar a ponte que os cosméticos fazem de si com o outro e de si consigo mesmo, uma preocupação filosófica e quase de fé. O uso dos cosméticos revelaria um tipo de relação e de ansiedade com passar do tempo. No caso das mulheres, além disso, há as pressões sociais por um certo padrão de beleza, "uma hipocrisia da sociedade que lhes impõe esta expectativa".

"Os produtos de tratamento sempre se ofereciam a devolver a juventude ou a manter a juventude de uma forma, do meu ponto de vista, modestíssima do ponto de vista da intelecção, da compreensão: uma promessa pura e simples dissociada de qualquer possibilidade de compreensão ou lógica. O que eu pensei naquele momento é que o que está no fundo da ansiedade das pessoas pela - independente de uma ideia vaga de beleza que se tenha - manutenção do corpo, do seu estado, da sua idade mais jovem, é o medo da morte. E comecei a estudar um pouco os aspectos desta ansiedade 
que nos une a todos. (...) Sem ser religioso, acho que a verdade liberta. (...) Com transparência, é muito mais fácil viver. Nasceu daí uma paixão: a paixão pelos cosméticos e o potencial de uma linguagem nova".

Desse modo, Luiz Seabra deixava de simplesmente ser um gerente técnico do laboratório de Pierre Berjeaut para alguém cada vez mais interessado pela área de cosméticos a que se dedicava. Sua proposta era criar uma "nova linguagem" para aquele mercado. Nesse momento, uma oferta em particular permitiu desenvolvê-la: Pierre Berjeaut ofereceu a Seabra sociedade no laboratório. Por se tratar de uma empresa com passivos fiscais que não lhe interessavam, Seabra sugere fechar o antigo laboratório. A família Berjeaut concorda e, através do filho Jean-Pierre Berjeaut, criam uma nova empresa, que seguiria fornecendo produtos para o instituto da Rua Haddock Lobo. Além disso, a nova empresa teria um objetivo: ampliar a produção para alcançar um mercado maior do que o público atendido por Berjeaut, através da criação de novos produtos. Esta era a tarefa, na sociedade, de Luiz Seabra.

As reflexões sobre a "função social do cosmético", a "relação de si com o outro" e a falta de "intelecção" que povoavam o setor, resultado de suas novas experiências e das leituras e conhecimentos que adquiriu com o tempo, teriam sido decisivas para que Seabra, mesmo a princípio não conhecendo o ramo no qual ingressava, pudesse desenvolver novos produtos e concepções que acabariam norteando o que viria a ser a gigante brasileira de cosméticos. $\mathrm{O}$ sucesso profissional e posteriormente empresarial teria sido alcançado pari passu ao acúmulo de conhecimento e ao desenvolvimento de suas inovadoras concepções; talvez, na verdade, em sua narrativa o sucesso tenha sido consequência de seus conhecimentos.

\section{A fundação da Natura: a "identificação de propósito" como "ilusão biográfica"}

\footnotetext{
"Naquele momento, para mim estava claro: está aqui a minha vida. É isto aqui o que eu vou fazer na minha vida. Vou abrir um parêntesis para contar uma - os franceses chamam de anecdote -, um 'causozinho', que está mais no âmbito das intuições, de uma linguagem de potencial nosso, que eu chamo de 'inteligência do coração', que eu teria percebido ou antecipado muito criança, muito jovem, que um dia eu iria fazer isto. Eu já contei em alguns episódios esta questão. Eu tinha doze anos. Eu tenho uma irmã mais velha - quase dez anos mais velha que eu - e, um dia, eu tinha doze e ela estava descrevendo que gostaria um dia de ter uma casa onde ela tivesse um espaço em que ela pudesse atender clientes. O que ela estava descrevendo eram as funções de uma esteticista: fazer limpeza de pele, etc. No momento em que ela descrevia que ela iria colocar nos olhos das clientes uma compressa, antes de tratar da pele, que ela iria fazer uma compressa, naquele momento eu tive um pensamento que
} 
não saiu da cabeça, eu tive um pensamento que saiu daqui de dentro [apontando para o coração]: eu vou fazer os produtos que elas vão usar em casa! Foi engraçado. Foi muito forte. Foi uma afirmação pura e simples. Uma identificação de propósito. E isto só voltou à minha mente mais tarde, quando eu comecei... Não foi nem quando eu comecei a trabalhar com cosméticos. Foi dois anos depois. Estava para nascer meu quarto filho, eu queria um outo emprego, eu precisava ganhar mais e aí o senhor Pierre me ofereceu uma sociedade na empresa. Eu disse que naquela empresa não me interessava, tinha um passivo fiscal, um passado que não me interessava ser responsável por ele e o que eu propus foi que fechássemos aquela empresa e abríssemos outra. Foi aí que nasceu o fundamento da Natura - porque ainda não era Natura”.

Dessa forma, Luiz Seabra explica sua atividade no ramo de cosméticos: um propósito de vida, algo para o qual ele já parecia como que predestinado desde a mais tenra idade. As décadas que sucederam o diálogo com sua irmã até a Natura tornar-se uma empresa com a dimensão econômica que obteve poderiam ser, assim, vistas como um conjunto sucessivo de acontecimentos a provar este único fim, este propósito inscrito desde o princípio.

Pierre Bourdieu, em A ilusão biográfica (1998), mostra como a "história de vida", construída como um curso linear e unidirecional do sujeito, tem pressupostos. Apresentada como um conjunto coerente, revela a intenção subjetiva e objetiva de um projeto e, por isso, necessita de uma ordem lógica e cronológica, que possui um princípio, com duplo sentido - na medida em que é um ponto de partida, mas também uma razão de ser - e um fim, que é término e objetivo. Nesse tipo de empreendimento, o biografado seleciona acontecimentos como significativos e lhes dá coerência e direção, num tipo de postura que o autor francês caracteriza por "ilusão retórica".

Ora, ao longo da vida, o indivíduo transita por diferentes espaços e neles ocupa posições diferentes. O nome próprio, "uma formidável abstração" para Bourdieu, é a instituição primeira que confere identidade e a unidade do indivíduo através do tempo em diferentes espaços sociais. Cabe à investigação sociológica, então, não ser uma "forma doce de interrogatório" que legitima esta representação ou produção de si mesmo que o entrevistado realiza. É necessário mobilizar a noção de trajetória "como série de posições ocupadas por um mesmo agente (...) num espaço que é ele próprio um devir, estando sujeito a incessantes transformações" (BOURDIEU, 1998, p. 189). Para compreender a trajetória, como "envelhecimento social", é preciso buscar o conjunto de relações objetivas travadas pelo agente e as sucessivas posições que ele ocupou, levando em conta o "espaço dos possíveis" com o qual o agente se deparou em vários momentos. 
O espaço social, para Bourdieu (2011), é multidimensional, uma "topologia social" em que se pode ocupar um conjunto de posições possíveis. Os campos são frações do espaço social, uma espécie de campo de forças em que os agentes, localizados - como num sistema de coordenadas - em posições distintas disputam o poder numa luta constante. As posições devem-se à quantidade de capital que os indivíduos possuem e ao modo de distribuição deste. Para Bourdieu, há diferentes espécies de capital - econômico, cultural, social e simbólico - cuja predominância específica organiza a disputa no interior de cada campo. O campo é um espaço estruturado e relacional onde os agentes competem pelo poder, pelo monopólio legítimo de sua distribuição e por princípios de hierarquização.

Burawoy (2010) aponta semelhanças em tal concepção de "arena de lutas" em cada campo, desenvolvida por Bourdieu, com a teoria marxista do capitalismo. No entanto, há uma interessante inovação, já que o sociólogo francês tem sua atenção voltada à "coexistência simultânea" de diversos campos. Como diferentes espécies de capital e de princípios organizam a luta no interior de cada campo, nem sempre aquele que ocupa posição dominante em um deles terá necessariamente a mesma posição em outro. No ápice das posições possíveis de se ocupar no campo econômico, Seabra, que possui grande quantidade de capital econômico, tem relativamente menor quantidade de capital cultural acumulada, por exemplo, sob a forma de títulos escolares e reconhecimento acadêmico. No entanto, o empresário busca uma homologia de sua posição dominante também no campo cultural e científico, por meio da mobilização de diversos conhecimentos e leituras que se esforçou para acumular ao longo do tempo. Reforçando o efeito simbólico dessa posse, além disso, Seabra reafirma a posse de grande capital social, sua relação por exemplo com os economistas e intelectuais da “Casa das Garças", ministros, acadêmicos, a menção aos anos sabáticos que passou na França e na Inglaterra, refletindo sobre sua vida e atividades. É com este arsenal que ele conta quando lida com o sociólogo que o entrevista.

Por outro lado, a reconstrução da trajetória de Seabra, a "ilusão retórica" que apresenta sua atividade nos cosméticos como um propósito, uma missão, presente desde a infância, só pode ser feita pelo empresário bem-sucedido de muitos anos depois. Por isso, é possível que ele apresente o sucesso nos anos posteriores à sociedade com JeanPierre Berjeaut como obra exclusiva de sua visão empresarial e do desenvolvimento de uma nova "linguagem" para os cosméticos. 
Uma passagem interessante de como Luiz Seabra reconstrói a criação da sociedade empresarial pode ser mobilizada como exemplo da "ilusão retórica" de que fala Bourdieu. Seabra foi primeiramente contratado para trabalhar no laboratório de Pierre Berjeaut e, posteriormente, mesmo como parte da sociedade, seu "investimento" foi sua capacidade de trabalho.

"[Jean-Pierre] representava a família. Ele tinha $80 \%$ da sociedade e eu tinha $20 \%$. Estes 20, eu não entrei com capital porque eu não tinha. Eu entrei com... Eu potenciei... com, com... Era o capital intelectual. E ocorreu que, passados dois meses ou três ocorreu um rompimento familiar".

O empresário de sucesso de hoje, no entanto, tem dificuldade de expressá-lo. $\mathrm{Na}$ sociedade, ele entrou com... trabalho! Mas, em seu relato, se trata de "capital intelectual", que se desenvolveu ao longo dos anos através de suas incursões pela Filosofia, o que lhe permitiu, na Natura, desenvolver uma "linguagem" completamente nova no mercado de cosméticos. O empresário Seabra tem dificuldade de expressar que, como vinha ocorrendo até então em sua trajetória profissional, na sociedade, ele não tinha capital (econômico) para investir: ele iria, portanto, trabalhar na nova empresa da qual era sócio. Porém, na narrativa, seu trabalho concreto sai de cena e dá lugar ao "capital intelectual", a forma por ele encontrada para nomear suas capacidades, advindas das reflexões e conhecimentos que havia buscado ao longo dos anos - as verdadeiras responsáveis, em sua opinião, pelo sucesso posterior da companhia que recém surgia. A ascensão econômica de Seabra, desse modo, e também o acúmulo de capital econômico $^{67}$ são por ele creditados a suas capacidades próprias e seu aprendizado no terreno da Filosofia, não pelo aumento paulatino da produção e da produtividade dos trabalhadores da empresa, que aparecem maquiados, escondidos, em seu relato, como se tentará mostrar.

Uma briga familiar quase levou ao fim da sociedade meses depois de seu estabelecimento. Pierre Berjeaut propôs que a empresa fosse fechada e que Seabra voltasse a trabalhar no instituto. Ele, no entanto, tinha outros planos.

\footnotetext{
${ }^{67}$ Vale relembrar, a respeito, o "conselho" dado por Seabra, quando me perguntou o porquê da escolha pela Sociologia, ainda com o gravador desligado: ele dizia que, se eu estava satisfeito com ela, deveria seguir em frente, afinal, em sua opinião, "não se deve buscar o dinheiro, mas sim nossa realização humana" e que, a partir dela, se pode alcançar o sucesso. Trata-se de um "conselho", no mínimo interesse, mas pouco crível, de ouvir da voz de um bilionário. Na entrevista já mencionada à "Época Negócios", por sua vez, ele afirma que o dinheiro é "um meio de acesso à beleza, à harmonia, não apenas da forma, mas também dos sentidos, para me cercar do que é belo e promovê-lo na sociedade".
} 
"Eu iria lutar pela minha empresa. Meu compromisso era com a minha empresa e com a minha sociedade. Se eles estavam rompendo o compromisso familiar existente, de o Jean-Pierre representar a família, era um problema entre eles, mas eu era sócio do Jean-Pierre e eu ia lutar por esta sociedade. E assim foi. (...) Foi nesta ocasião que nós mudamos a denominação da sociedade e passou a ser, a partir de... A empresa foi fundada em fins de agosto de 1969. Em fevereiro de 1970, portanto, seis meses depois, ela passou a chamar-se Natura".

A Natura surgiu com uma pequena loja na Rua Oscar Freire. O acordo com Pierre Berjeaut garantia a compra pelo instituto de estética de 3 meses da produção da empresa. Posteriormente, seria preciso encontrar mercado. Tempos difíceis que Seabra chama de "anos heroicos". Jean-Pierre, 4 anos mais jovem que Seabra, detestava cosméticos, tinha pouca experiência profissional e não gostava do contato com clientes. "Era o típico filho de uma família bem posicionada, ricos, para o padrão da época", afirma. Seabra, então, desdobrava-se. Atendia no balcão e 3 vezes por semana ia a casa de clientes, quando uma balconista o substituía na loja. Além das visitas, passou a dar palestras em que "fazia uma ponte entre estas reflexões de ordem meio filosóficas a respeito da vida como propósito e da estética como um instrumento para a ampliação, o aprofundamento, o cultivo da autoestima".

Em sua atividade como revendedor, indo à casa das clientes, Seabra teve que lidar com seus preconceitos, já que, para ele, no princípio, seu trabalho era semelhante ao de um cabeleireiro. Seabra afirma que se tratou de uma "experiência existencial" atender as clientes, a partir da qual a Natura fez a opção do formato de distribuição de produtos através das consultoras, atividade que até hoje caracteriza a empresa e na qual, atualmente, está mobilizado um exército de 1,5 milhão de pessoas ${ }^{68}$.

A “ilusão biográfica" de Seabra, que vê o início das atividades da empresa como um propósito ou uma missão, ganha conotações espirituais e religiosas inclusive - por mais paradoxal que possa parecer ao pensamento liberal e à lógica instrumental que em geral deveria presidir o comportamento de agentes empresariais. No momento de dificuldades logo após a ruptura na família Berjeaut, Luiz Seabra consultou-se com o médium armênio, Sana-Khan, a quem conheceu por intermédio de Dona Ondina, esposa do vidente e quiroprático, cliente do antigo departamento de barbeadores da Remington Rand. Segundo conta, Sana-Khan era famoso no período por ter entre seus clientes personalidades como Getúlio Vargas e Miguel Arraes.

\footnotetext{
${ }^{68}$ Ver Abílio (2011) (2012).
} 
"Fui procurar o professor - eu o chamava de professor - e contei: 'Professor, esta é a minha empresa, nessas condições e agora estamos nesse impasse. O que o senhor acha?' Ele olhou para minha mão, mas ele já a conhecia bem, olhou para a minha testa, fez um olhar meio esgazeado e falou assim: 'Estou vendo um trator, que vai marchar muito lentamente no início, mas vai gerar uma força que nada vai conseguir deter, vai alimentar legiões, tanto material quanto espiritualmente. Semear é o seu destino'. Eu saí dali, rapaz, arrepiado e com um entusiasmo que me acompanha até hoje. Primeiro, pelo que eu ouvi, mas, fundamentalmente, porque o que eu ouvi fazia sentido com a intuição que eu tinha. Eu achava que tinha uma missão social para esse projeto".

A adoção da distribuição de produtos por meio das consultoras, desse modo, é apresentada como mais um dos lances geniais do fundador da Natura, uma "experiência existencial" que revela a preocupação pelas relações. Este quesito, quase de alteridade, é enfatizado em detrimento do próprio significado econômico que a atividade das consultoras teve na consolidação da empresa e de seu mercado. Se, por um lado, a atividade das consultoras é narrada apenas como uma reprodução do caminho iniciado por Seabra, seu papel determinante para a ampliação de mercado da companhia e, além disto, o trabalho produtivo na empresa, por outro, sequer aparecem.

À "identificação de propósito" que dá sentido à reconstrução da história de vida do fundador da Natura poderia somar-se outra identificação de propósitos, no plural: identificação que a empresa tenta construir entre, por um lado, seus objetivos econômicos, metas, produtividade, concepção a respeito da organização dos trabalhadores; e, por outro, as aspirações e desejos dos próprios trabalhadores. Nesse âmbito, ainda que não sejam objeto de discussão no presente capítulo, podem-se mencionar o programa de formação e certificação interna (chamado, de modo eloquente, "Meu Caminho"), a adoção de metas relacionadas ao Programa de Participação nos Lucros e Resultados (PLR) - que têm impacto decisivo nas atividades diárias dos trabalhadores na produção -, e as atividades permanentes de educação corporativa, entre outras práticas de gestão da força de trabalho e da produção adotadas pela Natura.

Para que tal "identificação de propósitos” entre empresa e homem possa ocorrer, ao menos do ponto de vista do discurso empresarial que justifica suas práticas de gestão da produção, é preciso maquiar o trabalho, escondê-lo, ocultá-lo, mesmo que sob uma aparente transparência como a que postula a Natura, o que se pretende abordar na seção seguinte. 


\section{A opacidade do trabalho na consolidação da gigante dos cosméticos}

A adoção do sistema de vendas diretas, na Natura conhecido como a venda por meio das "consultoras", é apontado por Seabra como um fator decisivo na consolidação da empresa num mercado onde havia competidores estabelecidos e muito maiores, como a estadunidense AVON. Mas o que diferenciaria as estratégias de ambas as companhias? A que se creditou o crescimento da Natura? Para Seabra, o fundamental é que sua companhia soube valorizar as "relações" estabelecidas com as clientes por meio de seu sistema de "consultoras".

Em sua experiência como representante, destaca a importância do contato com as clientes e não apenas a venda dos produtos. Por isso, apesar de ter cogitado optar por um sistema de franchising - à época não existia ainda O Boticário - para a Natura, fez a escolha, segundo diz, de "multiplicar os Luizes", num mercado em que a competição já era grande e onde estava instalada fazia algum tempo a AVON, pioneira no uso do sistema de venda direta de cosméticos no país.

"Aquele que você está sendo quem pode explicar é o outro. Explicar não diretamente, mas como espelho. Você se perceber no outro. E o outro pode receber de você o que o Platão chamava das palavras que curam e das palavras que envenenam. Você pode escolher as palavras que curam, as palavras que fermentam vida. E foi esse tipo de intuição, de percepção, de constatação que eu fui cultivando e percebendo a partir das entrevistas com as clientes. Então, na ocasião, eu comecei a explorar a ideia de que a nossa empresa, que nasceu completamente sem capital - e, portanto, era uma antiempresa -, tinha como capital duas paixões: a paixão pela cosmética na percepção que nós tínhamos da cosmética e a paixão pelas relações porque percebíamos que isto é o que fundamenta a vida".

Daí a opção, então, pelo sistema...

"Justamente. O sistema de venda direta. Ao invés de multiplicarmos as lojas, preferimos multiplicar os Luizes. Multiplicar aquelas que viriam a ser as nossas consultoras".

\section{Essa estratégia a AVON utilizava já no Brasil?}

“A AVON é que abriu a estratégia, que era embasada, antes de mais nada, em um regime fiscal, não é? Tem um regime fiscal especializado para permitir que essas senhoras - a maioria continua sendo constituída por mulheres, embora tenha chegado a $5 \%$ o contingente de homens, mas ainda é modesto (...) -, elas estão abrigadas por um regime especial, ligado a impostos estaduais, que permite que a empresa seja responsável pelos impostos, incluindo a atividade comercial da representante, da consultora, no caso. A AVON tinha aberto isto já dez anos antes de fundarmos a Natura. Eu acho que foi em 59 ou 58 que a AVON foi inaugurada no Brasil e nós em 73 começamos a fazer algumas experiências com distribuidores, que foram experiências decisivas, que mostraram que tinham um potencial muito grande para nós realmente encontrarmos uma estrada, que nos entregasse escala, que tivéssemos escala, porque até então era muito limitada a nossa produção. Só que tinha um grande problema: a qualidade do distribuidor. Os distribuidores que nós encontrávamos davam um trabalho muito grande para pagar. Um amadorismo. Se hoje, no Brasil, ainda existe muito 
amadorismo em muitas áreas, você imagine naquela época. Então, nós, de posse dos dados positivos, eu abri uma distribuidora, dissociada da Natura. E por que precisava ser [dissociada]? Precisava ser uma atividade, uma unidade voltada para a especialidade de vendas. E, se fizéssemos isto na própria Natura, tinha um impedimento pecuniário grande porque o IPI sempre foi pesadíssimo na indústria cosmética. O valor do IPI teria que ser calculado sobre o preço final do produto e isto inviabilizava economicamente o projeto. Então, eu montei uma distribuidora separada, com uma sociedade diversa também, porque senão seria uma operação em que nós poderíamos ser impugnados, e então montei a primeira sociedade em distribuidora separada da indústria, da Natura, com o propósito de que aquele seria o laboratório de atuação da Natura no mercado. E foi assim que prosperou o negócio. A partir daí, em 74, nós não paramos de crescer".

A pouca disponibilidade de capital - que faria da Natura uma "antiempresa", como apontado por Seabra, -, na verdade, é o que talvez possa ter inviabilizado uma estratégia de abertura de lojas e de franquias. Por outro lado, a experiência de alguns anos da AVON com o sistema de venda direta tenha sido um impulso talvez ainda maior do que a conversão filosófica à importância das relações. As consultoras não têm nenhuma relação formal de emprego com a Natura. O fato, além disso, de que um regime fiscal diferenciado permita à empresa assumir os impostos referentes à distribuição torna a atividade mais interessante.

Seriam necessários muitos anos para que a Natura pudesse superar a AVON em participação no mercado brasileiro, o que só ocorreu na virada dos anos 2000. Até lá, a empresa expandiu suas atividades, a produção e o número de consultoras. Luiz Seabra aponta, no entanto, para uma ênfase distinta com relação ao sistema de venda direta que teria permitido a sua companhia superar a concorrente: a aposta numa certa virtude comunicacional brasileira e um tipo de relação diferenciada com as clientes. Para obtêla o próprio Seabra ainda hoje se envolve numa série de atividades motivacionais e de formação com as consultoras. Seria uma espécie, retornando ao debate inicial com gravador desligado, de incursão do "homem cordial" no tradicional sistema de venda direta estadunidense.

\section{Como foi possível enfrentar a concorrência da AVON?}

"Tradicionalmente, no sistema de venda direta, há uma obsessão pelo sistema em si. É o que os americanos às vezes jocosamente diziam que, mesmo que você venda snake oil, que o sistema é o que é vigoroso e ele vende qualquer coisa. A força do sistema prevalece. Nós nunca enveredamos por esta linha porque estávamos apaixonados por cosmético e é suposto do cosmético que ele tenha qualidade".

\section{Seria uma incursão do "homem cordial" na estratégia?}

"Muito possível. Aliás, eu não cheguei a explicar. Eu, por exemplo, no exterior, na França, eu sempre, em algumas entrevistas, explorei a ideia do homem latino, especificamente do homem brasileiro, como homem cordial, mas o seguinte: o 
cordial como base do coração interagindo, do cordis, a etimologia. Eu gosto, sem ser profundamente conhecedor, mas eu gosto muito de linguística porque eu acho que as palavras têm conteúdos. (...) [comenta algumas de suas leituras na área]. Eu frequentemente avalio a questão da cordialidade como uma potencialidade para a empresa brasileira na sua busca de ampliação internacional porque o Brasil é muito valorizado lá fora. Porque é um pouco o país da evasão, da luminosidade, mas a luminosidade do céu, a luminosidade da presença solar tem uma correspondência com a luminosidade dos afetos. E eu acho que isto é valorizado lá fora e de certa forma, se for norteado pela ética - no fundamento das percepções que nós tivemos tem uma ética, uma ética própria, sem querer parecer pretensioso, mas tem uma ética própria -, uma ética das relações. Se a hipótese que a gente tem vivido e colocado é de que a cordialidade vivida com parâmetros da ética pode ser uma força”.

Em sua reconstrução, as atividades produtivas da empresa têm pouco lugar. É uma espécie de opacidade do trabalho. O que realmente conta, para Seabra, no crescimento da Natura são os códigos, a linguagem, a ética e os slogans criados. O que aparece em sua narrativa são as concepções que nortearam sua trajetória como empresário. De concreto, aparece apenas a atividade das consultoras, que não é parte da produção, e mesmo assim sob a forma de "Luizes" multiplicados. O segredo da gigante brasileira dos cosméticos seria, então, devido à luminosidade brasileira e à transparência das relações da empresa com seus consumidores e acionistas. A enorme produtividade e a escala de produção alcançadas seriam, desse modo, questões contingentes, não na atividade cotidiana dos gestores, por óbvio, mas na maneira como o discurso empresarial organiza-se.

Ao falar da construção da moderna planta de Cajamar, inaugurada em 2001, quando se instalou novo maquinário e se adotaram novas técnicas de produção, Seabra valoriza outras dimensões, em particular a questão da "responsabilidade ambiental", convertida, na realidade, num elemento fundamental de publicidade da Natura. Uma fábrica pensada para um novo momento da empresa, quando se planejava finalmente alcançar a liderança nacional no ramo de cosméticos e a ampliação de seu mercado internacional.

"Sem dúvida, nosso crescimento no Brasil, assim como nosso projeto de expansão internacional, impunha que ocupássemos uma nova planta. Porém, o novo espaço em Cajamar representava para nós muito mais do que abordar novos mercados, crescer em termos materiais. Este projeto representou para a Natura a oportunidade de, a partir do zero, corporificar no espaço nossa visão de 'bem estar bem', assim como expressar nossas crenças, nosso compromisso ambiental e social. Cajamar representa para nós o símbolo do poder do sonho e da utopia (...).”

Como a Natura tem entrado no jogo global em seu processo de internacionalização? 
"Primeiro, nós achamos que ainda não estamos no jogo global não. Estamos longe disso. Um pouco longe. Mas começamos algumas experiências internacionais nem por planejamento estratégico, mas porque algumas pessoas se interessaram pela nossa linha para atuar lá fora. Houve um ex-vendedor, um gerente de vendas chileno que nos levou para o Chile, isto há mais de trinta anos. Não foi intencional, mas começou a nossa operação no Chile. Houve um senhor que começou a operação em Portugal. Depois, nós demos continuidade e fechamos porque não justificava e essas foram algumas experiências episódicas. Quando começamos, de forma planejada, foi há cerca de 16 anos atrás (...). Há 16 anos começamos a atuar de forma mais organizada, no México, depois começamos no Peru. Tinha uma operação que até hoje não é nossa presença direta, mas são distribuidores na Bolívia, mas é uma operação bastante pequena. Então, Chile somos nós; Peru somos nós; Argentina somos nós; Colômbia, mais recentemente, estamos há dois para três anos na Colômbia. No México, nós já estamos há sete anos como uma operação crescendo, uma operação grande (...). A AESOP é uma operação pequena, uma empresa australiana que nós compramos o controle. O fundador continua nosso sócio. Eles tinham um fundo que detinha uma participação grande, nós estamos ainda concluindo todo o processo para ficarmos detentores de cerca de $60 \%$ dessa empresa. É uma empresa que nasceu na Austrália, mas já com uma certa vocação internacional. Eles têm 60 lojas em 11 países. Estão na França, onde nós estamos também, você sabe, há 7 anos. (...) estamos há 7 anos na França com uma flag-ship store [loja-conceito], uma pequena loja, simpática e fomos, paralelamente, 3 anos depois ou 2 anos depois que inauguramos a loja, um sistema de venda direta também. Temos cerca de 3000 consultoras na França. Mas a França, por definição, não é um país para venda direta. Já é um pequeno milagres isto que a gente faz lá. E está ainda num ponto imaturo do potencial de mercado na França. E provavelmente vamos ampliar, multiplicar, a operação com um número maior de lojas porque é o que funciona melhor na França e em outros países do Primeiro Mundo. Experiência que esta aquisição ${ }^{69}$ [da AESOP] vai nos agregar bastante porque eles atuam com lojas próprias, onde você encontra apenas esta marca”.

A planta de Cajamar, sua nova organização por "rios" e seu regime de metas que levam a uma intensificação crescente da produção permitiram à Natura manter-se como empresa-líder em seu ramo. Seus principais acionistas passaram a frequentar as listas de maiores fortunas do país e do mundo. As receitas e lucros bilionários da empresa alcançaram desde então níveis recordes. Curioso que numa empresa como esta os conflitos na produção e a organização dos trabalhadores quase não apareçam, estejam opacos, por trás de uma permanente e "transparente" busca pela aderência à "essência" empresarial.

A "guerrilha simbólica" vivenciada durante a entrevista com o fundador da Natura mostrou como o empresário, bem sucedido sob a lógica do campo econômico, expunha seu acúmulo de outra espécie de capital, o capital cultural, numa forma de buscar em outro campo uma homologia com a alta posição que ocupa no campo econômico e, dessa forma, se colocar em situação de igualdade ou mesmo de superioridade com o sociólogo, de quem se esperaria ocupar uma posição mais

\footnotetext{
${ }^{69}$ Discutida no capítulo 1.
} 
privilegiada nos campos acadêmico e cultural. No entanto, além disso, a "guerrilha simbólica" revelou uma luta tácita em que estava em jogo, para Seabra, a defesa da doxa da empresa, de seus princípios de organização, confundida com a própria reconstrução biográfica do empresário. E são exatamente estes princípios de organização, vocalizados por Seabra, que estruturam as relações sociais na produção. Pode-se dizer, então, que opacidade do trabalho visível em seu discurso é a contrapartida das formas de organização do trabalho e da produção, apresentadas como "transparentes", na empresa.

A entrevista com Luiz Seabra mostrou como a narrativa sobre sua trajetória se confunde com o discurso empresarial, num movimento de reconstrução de sua biografia que pode ser visto como uma "ilusão retórica" (BOURDIEU, 1998). Em alguns momentos, na verdade, pode-se dizer até que o empresário é a encarnação deste discurso, no qual o trabalho tem lugar secundário e aparece obscurecido por outras questões: a "função social do cosmético", as especificidades da atividade das "consultoras" como capazes de manter com clientes uma relação de "alteridade", o lugar privilegiado da "responsabilidade ambiental" na construção da planta de Cajamar, em detrimento de aspectos decisivos da mudança na organização da produção, com o consequente aumento da produtividade, etc. Descrita desse modo a história da companhia, ficam algumas questões: qual o lugar de categorias como trabalho e exploração? Que relação é possível estabelecer entre elas e a "guerrilha simbólica" mantida durante a entrevista ou a "ilusão retórica" ao redor da descrição da trajetória de Seabra e de sua empresa?

O capítulo seguinte, que sistematiza as conclusões desta dissertação, pretende debruçar-se sobre questões como estas. A tentativa será avaliar, à luz das discussões precedentes, o modo como a Natura pôde até aqui ser bem sucedida na mobilização dos trabalhadores ao redor de suas metas e expectativas, ou, dito de outra forma, os fundamentos da aceitação pelo grupo de trabalhadores do que aqui se apresentou como um permanente paralelismo entre a "transparência" pregada pelo discurso empresarial e sua "opacidade" no que se refere aos efeitos da organização da produção sobre os trabalhadores em termos de intensificação do trabalho, competição entre os pares, erosão da solidariedade coletiva e mesmo o aparecimento de lesões como situaçãolimite da busca do "comprometimento". 


\section{Capítulo 5 - Como breve forma de concluir: "opacidade" do trabalho e "transparência" empresarial como expressão da "dupla verdade do trabalho"}

A organização da produção na Natura por meio das células semiautônomas e do TPM, as avaliações de "aderência à essência" e o discurso de muitos operários que trataram suas colegas lesionadas demitidas como "encostadas" e "inúteis" mostram que a empresa tem obtido sucesso em sua estratégia de mobilização de um grupo operário renovado para dar conta de suas expectativas e metas. Como forma de conclusão, pretende-se fazer alguns breves apontamentos a respeito de uma clássica questão da Sociologia do Trabalho: por que, então, os trabalhadores parecem consentir com as formas de controle e organização do trabalho na Natura?

Como visto no capítulo 3, a PLR foi fundamental para garantir a intensificação do trabalho e o aumento da produtividade, portanto dos lucros, que caracterizaram a empresa no período posterior à reestruturação, com a inauguração da planta de Cajamar (2001), a abertura de capital da empresa (2004) e a nova "onda" de internacionalização $^{70}$ da empresa inaugurada por sua nova política de fusões e aquisições (2012). Conforme disseram diversos trabalhadores da empresa, o valor anual da PLR é o verdadeiro diferencial de rendimento na Natura em comparação com outras empresas do setor, já que não há diferença no que se refere aos salários pagos. Márcia, diretora do Sindicato dos Químicos, mostrou que o comportamento da empresa nas negociações anuais de dissídio e sua política salarial também seguem este princípio: não pagar salários superiores ao do setor cosmético, diferenciando-se, no entanto, nos valores de PLR distribuídos anualmente.

A contrapartida para este diferencial do valor da PLR pago na empresa está na permanente preocupação com a consecução das metas no interior do grupo de trabalhadores. Como visto, esta disposição a atender as expectativas empresariais quanto ao aumento da produtividade, dos lucros anuais, da diminuição do desperdício de materiais ou da eficiência das máquinas, por exemplo, é o pano de fundo das próprias relações no interior da célula. A ausência de mobilização quando da demissão de 33 trabalhadoras demitidas e a queixa destas com a estigmatização que viveram no período em que atuavam na célula de retrabalho para lesionadas parece demonstrar os efeitos

\footnotetext{
${ }^{70}$ Conforme descrição de Renato Andrade e Pedro Lima no capítulo 1.
} 
das metas na sociabilidade operária. Por sua vez, o relato de Flor também mostra o medo da demissão e da falta de aceitação dos colegas como presença constante entre trabalhadores lesionados que optam por seguir trabalhando em seus limites físicos para não serem identificados como aqueles a quem falta "comprometimento" com a empresa e também com os colegas ao dificultar que estes atinjam coletivamente as metas e, por esta via, ganhem a PLR integral.

Susana Diniz mostra como há limites demarcados e claros sobre a proposição e alcance das metas. A alegada ampliação da "autonomia" do trabalho presente no sistema de células, no entanto, se dá no justo limite do que é requerido pelo controle capitalista com relação às expectativas de produção e realização dos lucros.

"As metas são dadas basicamente... Elas [as trabalhadoras e trabalhadores] têm uma meta anual. Então, elas já têm os caminhos. E elas têm metas por categoria, por período do ano... Elas combinam com o gestor o que elas têm que fazer naquele momento (...). Aí, a combinação é como atingir as metas, mas as metas macro já são dadas pela organização. Então, ele tem um limite que ele pode negociar e outro limite que ele não pode. Aí ele sabe: se ele tem que fazer isto, ele tem que fazer. Aí ele fala: 'vamos fazer mais rápido e ganhar mais, ou tem uma outra questão que a gente ganha mais tempo aqui'... Eles vão determinando a forma de fazer isso e às vezes, com um novo modelo de apoio, com uma nova forma de se colocar na máquina, ganham mais tempo. (...) Na verdade, [o controle do trabalho dos colegas no interior da célula] é muito mais pelo princípio de células semiautônomas do que do TPM. Com certeza, o conceito está muito mais ligado a isto: que você tem autonomia para buscar resultados que são melhores e para ganhar autonomia e responsabilidade. De você ser gestor daquilo. A melhor pessoa para saber fazer o processo são essas pessoas. Elas que sabem como fazer".

Em sua fala, fica clara a articulação entre o regime de metas e a organização da produção por meio das células para capturar, como argumentou Durand (2003), o savoir-faire operário. É possível ver o ganho de "autonomia e responsabilidade" de que fala Diniz como a busca pela melhor forma de trabalho, no tempo ideal, de modo a atender às exigências do fluxo e das metas. É a isto que ela se refere quando afirma que os trabalhadores são quem melhor sabe como fazer e organizar o trabalho. O estímulo do ganho econômico da PLR é requisito fundamental para que se possa transformar este savoir-faire em organização ótima da produção. No entanto, ao sugerir que os trabalhadores da empresa preferem esta forma de produzir, por se tornarem de certa forma "gestores" da própria produção na célula, Susana Diniz mostra que não apenas a dimensão do ganho material contida na PLR está presente.

A satisfação com tais aspectos de "autonomia", como se verá adiante, joga um papel fundamental na garantia das condições para obter o savoir-faire operário a serviço do alcance das metas empresariais e do tempo ótimo de produção. Norma, ao falar sobre 
como os trabalhadores reagem se eventualmente discordam de alguma meta proposta, mostra exatamente como a satisfação com estes espaços de "autonomia", de "diálogo" e de "participação" - ou "liberdade", em suas palavras - faz com que as metas sejam vistas muitas vezes não com uma pressão pela intensificação do trabalho, mas como uma possibilidade de melhora da própria atividade de produção diária na célula.

“Algumas coisas [sobre as metas] a gente questiona, né, quando não é muito viável para a gente. A gente questiona. Mas eles mostram o lado do crescimento. Eles mostram a visão assim: não é uma meta para punir ninguém. É uma meta para mostrar quanto a gente está indo bem. Porque não é a culpa da pessoa do operacional. É mais a culpa do equipamento. Então, é buscar melhorias mesmo - 'Essa máquina está dando problema. Será que não é melhor comprar, investir em outra máquina ou fazer aquela mudança radical nela, mudar?' - então é mais para chegar nesse ponto mesmo esse estudo, essa análise. Para a gente é ótimo porque a gente adquire conhecimento, a gente fica mais atualizado aí para o mercado. Que nem eu vejo: as pessoas que saem daqui não tem dificuldade para arranjar emprego lá fora. [...] Aqui a gente conversa de igual para igual. A gente tem a liberdade de ir tanto na gerência quanto o gestor e de dar um retorno, um feedback positivo ou negativo. (...) Se, por exemplo, uma máquina está dando muito problema. Vai ocasionar o quê? Um retrabalho. Então, isso frustra a equipe. Se a gente se sente na obrigação de atingir aquele determinado produto, então corta vendas. E se corta vendas não é legal para nós. Então a gente vai lá e passa para o gestor, passa para a gerência e fala: 'Não tá legal. A gente quer saber qual a atitude de vocês, qual o plano, vocês estão cientes que vai acontecer um retrabalho na linha, não vai estar legal'. Então, eles vão lá e tomam essa providência”.

\section{"Uma certa liberdade"}

[Mônica] "É assim. Esse mês, por exemplo, a gente tem que atingir - a fábrica - 15 milhões de produtos. [Na fábrica] Rio São Francisco. Aí, cada hora é tantos mil que a gente tem que fazer. Então, a gente vai controlando isto. Vamos trabalhar com... por exemplo, se o equipamento estiver ruim, aí é o mecânico que mexe. Se for coisa que dá para a gente mexer, a gente mexe para poder ser mais rápido o processo, se não o mecânico vem mexer e a gente tenta ajudar ele para poder atingir essa meta. E cada linha também tem a sua velocidade, tem o seu OEE - que é a eficiência global do equipamento - que é contado por um coletor [em] que lá a gente coloca os códigos de todas as paradas da máquina. É esse o nosso controle. Eles passam o que a gente precisa fazer e a gente tem que controlar para poder atingir o que eles pedem, mas sem muita pressão. Pelo menos na fábrica em que eu trabalho. Tem uma certa liberdade e, com isso, acaba até atingindo porque não tem aquela pressão o tempo todo".

[Thiago Aguiar] E se não atinge, o que acontece?

[Mônica] "Se não atinge? Olha, desde que eu estou aqui, dificilmente não atingiu. Mas, se não atinge, eles fazem uma maneira de atingir. Por exemplo, com hora extra, revezamento de linha, feriado vem trabalhar, fazer hora extra, aqueles que querem, né? Também porque não pressionam a gente, faz a pessoa que quer. E, se vir bastante, ótimo. Se não vir, bom também".

\section{[Thiago Aguiar] E o que vocês recebem de PLR depende das metas.}

[Mônica] "Das nossas metas. Exatamente por isto que a gente busca atingir as metas, né, porque a PLR, a maioria da parte da PLR, é as nossas metas". 
Mônica, auxiliar de produção na fábrica "Rio São Francisco", tem 22 anos. Em seu relato, a organização da produção por meio das células semiautônomas é vista como positiva, já que há "uma certa liberdade" em seu trabalho. Esta relaciona-se ao fato de que não há um superior pressionando permanentemente pela consecução do resultado. Isto não significa, no entanto, que a pressão e o controle na produção não existam. Na verdade, o que mudou foi a forma como o controle do trabalho é exercido. A pressão, agora, é anterior, por meio da determinação da meta a ser cumprida, e interior, no momento da produção na célula, quando o trabalhador mobiliza-se para atender às metas como forma de obter os ganhos da PLR. Interessante notar, a respeito, que Mônica afirme algumas vezes ser necessária a realização de horas extras e de trabalho extraordinário em feriados para atingi-las, mostrando que a intensificação do trabalho é realmente uma necessidade para atender às expectativas da empresa.

A lógica das metas e a submissão das expectativas do coletivo operário às disposições da administração da empresa, é tão internalizada que faz com que seja assumida como "uma certa liberdade". A pressão para atingir as metas, mesmo que envolvendo horas extras e intensificação, levando operários a assumir inclusive funções adicionais $^{71}$, é assumida como parte de uma espécie de jogo "ganha-ganha" em que a maior dedicação é assumida pelo coletivo operário, como um requisito tendo em vista o desejo de garantir a PLR. Ao mesmo tempo, no entanto, a possibilidade de controlar certas atividades na célula de modo a atingir as metas estipuladas é apontada por Mônica como uma espécie de respiro, de tranquilidade e satisfação com o trabalho, o que permite terminar atingindo mesmo metas difíceis.

Pierre Bourdieu, nas Meditações Pascalianas (2007), refletiu a respeito dos conflitos que se desenvolvem no espaço profissional entendido como campo. Na obra, ele apresenta o que considera ser a "dupla verdade do trabalho": de um lado, há a "verdade objetiva" da exploração, a apropriação do excedente de trabalho pelo capitalista; de outro, no entanto, há o que ele chama de "verdade subjetiva do trabalho". Trata-se de uma série de estímulos ao trabalho, que se encontram além da disputa pelo excedente econômico em si. Tais espaços de liberdade no trabalho criam uma "satisfação residual", que estimula os trabalhadores a produzirem, desconhecendo e se afastando, portanto, da "verdade objetiva" do trabalho como exploração. A "verdade

\footnotetext{
${ }^{71}$ Mônica, por exemplo, é "monitora de pessoas" e, entre outras questões de relacionamento no interior de sua célula, responsabiliza-se pela marcação de férias dos colegas.
} 
subjetiva" leva a encontrar um "ganho intrínseco, irredutível ao mero rendimento em dinheiro" no trabalho.

“(...) $\mathrm{O}$ investimento no trabalho tende a variar em razão inversa à coerção externa no trabalho. Por conseguinte, em diversas situações de trabalho, a margem de liberdade deixada ao trabalhador (a parcela de incerteza na definição das tarefas que abre uma possibilidade de jogo) constitui um móvel central: ela introduz o risco do nãotrabalho ou mesmo da sabotagem no trabalho, mas ela abre a possibilidade do investimento no trabalho e da auto-exploração. O que depende, em ampla medida, da maneira com que é percebida, apreciada e compreendida (...). Paradoxalmente, é porque ela é percebida como uma conquista (...) ou mesmo um privilégio (...) que ela pode contribuir para mascarar a coerção global que confere todo valor à liberdade. As ninharias a que se atêm as pessoas acabam por fazer esquecer todo o resto.

(...) Apoiando-se nesse princípio pelo qual a administração moderna deixa aos trabalhadores a liberdade para organizar seu trabalho, cuidando ao mesmo tempo de guardar para si o controle dos instrumentos de lucro, e contribuindo assim tanto para aumentar seu bem-estar como para deslocar o interesse do ganho externo do trabalho (o salário) para o ganho intrínseco (...)” (BOURDIEU, 2007: 249-250).

Mônica mostra, em seu relato, exatamente a que se referem a "verdade subjetiva" do trabalho e a possibilidade de obter "ganhos intrínsecos" no trabalho, de que fala Bourdieu.

"[A Natura] É uma ótima empresa para se trabalhar. Eu vejo mais ainda na produção. [...] Eu vejo que na produção a gente não tem liderança. A gente tem o sistema de GSA, que é gestão autônoma [por meio das células]. Então, a gente não tem líder. Tem o operador e o analista. O analista é para o turno todo. Não fica só ali numa linha, numa célula que a gente trabalha. Então aí a gente não trabalha sob pressão. Eu acho que isso é a melhor coisa porque quando a gente trabalha sob pressão não 'dá' as coisas tão certo porque você está sob pressão. Aqui na Natura, a gente tem uma liberdade. Tem academia [que os trabalhadores podem utilizar no horário de almoço ou fora do expediente], você pode conversar, no limite, mas pode, em outras empresas não pode. É bom por causa disso também. Tem berçário para quem tem filho. Tem até treinamentos de pessoas que estão gestantes, coisas que em outras empresas não existem. A lojinha, que a gente pode usar, tem desconto em produtos, pode usar os produtos que estão lá. Isso aí é o que eu acho legal e, querendo ou não, faz com que o funcionário trabalhe bem por gostar das coisas que a empresa oferece para ele".

Michael Burawoy (2010), em sua análise crítica da obra de Bourdieu, encontra interessantes paralelos entre a noção de "verdade subjetiva" do trabalho e o "jogo", que ele havia identificado em Manufacturing consent, como característica da organização da produção fabril. Para Burawoy (1989), é preciso, além das "relações técnicas na produção", lançar o foco nas "relações sociais na produção", que influenciam o comportamento do grupo operário. Dessa forma, a constituição de "jogos" de bater a meta de produção é interessante para a gerência da empresa na obtenção do consenso, mas, no entanto, também se relaciona com a satisfação residual do grupo operário de obter certo controle da produção e com a própria disputa simbólica entre os operários para ver quem domina melhor a produção. 
As convergências entre Burawoy e Bourdieu são interessantes, mas há uma divergência fundamental. Para Bourdieu, a separação entre "verdade objetiva" e "verdade subjetiva" deve-se às disposições acumuladas dos trabalhadores, a um habitus profundo que leva ao desconhecimento da exploração e a separação da "verdade objetiva". Na produção, portanto, está em questão uma doxa, uma dada organização e um sentido imposto pelos patrões, que os trabalhadores teriam dificuldade ou desconhecimento para questionar porque ali imperaria uma forma de "dominação simbólica".

Em outra direção, Burawoy (2010) aponta para a necessidade de ir além de tais "condições disposicionais" para revelar que a "mistificação, derivada da natureza das instituições que organizam e gerenciam o trabalho" é o que explica a separação entre as duas verdades do trabalho. Na produção, há instituições específicas que organizam o consentimento à dominação e que atuam da mesma forma sobre todos, independentemente de suas disposições acumuladas.

É possível dizer, então, nas trilhas de Burawoy (1985), que as metas e a PLR, os 'prêmios' incidentais de que falavam as lesionadas e mesmo o estímulo ao aumento da escolarização, gerando a expectativa de promoção, são aparelhos políticos que organizam o trabalho e o consentimento. Norma, ao falar sobre qual é a reação do grupo quando há um problema que impeça o bom andamento da produção, chega a falar na satisfação em realizar o "trabalho com qualidade".

[Thiago Aguiar] Você diz que o problema é ruim para a equipe, mas por quê? Por que vocês se preocupam com isto?

[Norma] “Ah, porque dá a impressão de que a gente não está fazendo o nosso trabalho com qualidade. E a gente gosta de fazer o nosso trabalho com qualidade. E, assim, é muito chato fazer um trabalho que já foi feito. Refazer ele. É ruim, frustra a gente. 'Ah, onde que eu falhei?', mesmo sabendo que aquilo [uma eventual máquina defeituosa] está ruim. Então, esse equipamento que eu falei, dando exemplo, a gente se vigia em dobro. A gente faz o nosso trabalho, mas a gente fica atento mais naquele ponto. (...) A gente quer trabalhar com qualidade. É a satisfação de ouvir o comentário, de ouvir as pessoas: 'Ah, você trabalha na Natura? Eu adoro os produtos de lá! É de ótima qualidade!'. Aí, ao mesmo tempo, você se defronta com isto".

[Thiago Aguiar] Qual a contrapartida a este comprometimento? Existe uma contrapartida, um reconhecimento, por parte da empresa?

[Norma] "Ah, sim! O comprometimento é um bom PGD [avaliação interna, quando, na equipe, uns avaliam e atribuem nota aos outros], entendeu? E a gente avalia os nossos gestores. Então, assim, é a garantia de um bom PGD, se a gente trabalha bem, entendeu? Em cima de um bom PGD a gente ganha bolsas de estudo, a gente tem facilidade melhor para subir de cargo porque, em caso de desempate, eu sou ótima e outra pessoa também foi ótima em tudo - dinâmica, entrevista - então, 'ah, vamos olhar o PGD', onde um se destacou mais do que o outro, entendeu? Então serve como desempate num processo de seleção. E aqui todo mundo pensa em crescer”. 
Como mostra Norma, a empresa estimula a expectativa pela promoção e cria benefícios externos ao salário (como se viu com os 'prêmios', spa e churrasco no caso das demitidas) - uma boa avaliação PGD e a chance de promoção. Estes elementos também são parte do que se poderia tratar como parte da "satisfação residual" que os trabalhadores encontram na empresa, para além do ganho salarial e do rendimento econômico. Aliás, vale a pena retomar a resposta, apresentada anteriormente na dissertação, de Norma quando se lhe perguntou, exatamente nesse ponto, se a contrapartida empresarial a este "comprometimento" também estava relacionada ao salário. Após reconhecer que o salário é igual ao de outras empresas e que a PLR é o que diferencia os ganhos na Natura, Norma reafirma que o que lhe satisfaz na empresa são "ganhos intrínsecos", como os sugeridos por Bourdieu.

"Sim porque a gente tem uma boa PLR. (...) Em termos de salário, tá igual o de outras empresas por aí, no mesmo patamar da Natura, no mesmo nível e, somando com a PLR, nosso salário eleva, né, fica em alta e aqui é legal pelo que eu falei. A gente tem a liberdade de ir ao RH, de passar algumas situações caso isso aconteceu, entendeu? (...) E o tempo todo eles estão treinando a gente. Eu falo: o tempo todo eles nos ensinam a nos defender, devido aos treinamentos que eles dão para a gente, a gente aprende a ter mais conhecimento, de até discutir de igual para igual porque eles são essa ferramenta para a gente".

Ora, o que revela o discurso empresarial da Natura senão formas de convencimento que podem ser mobilizadas como poderosos estímulos - externos ao puro rendimento econômico - para que os trabalhadores se dediquem à produção? Estas formas são apresentadas pela direção da companhia como uma relação "transparente" com os trabalhadores: das fábricas revestidas de vidro, passando pela política de "antecipar-se" ao sindicato - pagando meses antes do dissídio uma parcela do aumento que posteriormente será acordado ou apresentando a visão da empresa diretamente aos trabalhadores sobre eventuais conflitos - e mesmo pela busca de "educar" a força de trabalho sobre o "desenvolvimento sustentável" e sobre sua relação com o meio ambiente, dentro e fora de suas atividades na fábrica.

Nesse arranjo, questões relacionadas diretamente ao trabalho parecem sair de cena. Assim, a opacidade do trabalho, identificada na organização da produção e no discurso da empresa, pode ser vista como um modo eficaz de construir uma doxa, de criar um conjunto de concepções e instituições que afastam a "verdade subjetiva" dos 
diversos estímulos oferecidos aos trabalhadores em seu cotidiano e a "verdade objetiva" da exploração do trabalho. Com efeito, Bourdieu afirma que

\footnotetext{
"as novas técnicas de gestão das empresas e, em particular, tudo aquilo que se engloba sob o nome de 'administração participativa' podem ser compreendidas como um esforço para tirar partido, de maneira metódica e sistemática, de todas as possibilidades que a ambuiguidade do trabalho oferece objetivamente às estratégias patronais" (BOURDIEU, 2007: 250).
}

\section{Transparência e opacidade para "assegurar e obscurecer a mais-valia"}

Através da compreensão do papel do "jogo" e dos aspectos subjetivos do trabalho, Burawoy (1985) critica a posição de Braverman (1983), para quem a separação entre concepção e execução seria a marca do controle do trabalho no capitalismo. Ele afirma que tal distinção não é exclusiva do modo de produção capitalista após realizar a comparação entre este e o feudalismo e notar que concepção e execução também estão separadas nele. Burawoy, dessa forma, afirma que Braverman se preocupa sobremaneira com os aspectos "objetivos" do trabalho. Sem dedicar atenção aos aspectos "subjetivos", seria impossível analisar o controle capitalista do trabalho, para Burawoy. A própria distinção entre tais aspectos seria parte do problema, já que as respostas do "dia-a-dia" produzidas pelos trabalhadores mostram os segredos de como e por que os trabalhadores consentem.

A busca permanente, pelo capital, do aumento do trabalho não pago é o que marca o aspecto "objetivo" da relação capital-trabalho. Por outro lado, a resistência a tal aumento por parte dos trabalhadores é a consequência imediata desta busca. Por isso, o dilema do controle capitalista seria o de assegurar a mais-valia ao mesmo tempo em que deve buscar escondê-la. Tal relação de obscurecer e assegurar a mais-valia, e não a separação entre concepção e execução como propunha Braverman, é a essência do controle capitalista para Burawoy. E só é possível compreendê-la, em resumo, fazendo referência não apenas ao domínio econômico do trabalho senão também aos aspectos ideológicos e políticos, o que Braverman, para ele, subestimaria.

A argumentação de Harvey (2011) caminha em sentido próximo ao de Burawoy. Para ele, o desafio do capital, na produção, é fazer com o que o trabalho se engaje, tornando-lhe servil e diminuindo sua capacidade de resistência. Para tanto, uma série de táticas são utilizadas, entre as quais as diferenças sociais que percorrem o interior do 
grupo operário, dificultando-lhe a capacidade de resistir de modo organizado à exploração. Diversos relatos mostraram como a competição se desenvolve no interior do grupo de trabalhadores da Natura, ao redor de questões como bolsas de estudo, vagas no mercado interno de trabalho, prêmios, ou mesmo pela "picuinha", descrita por Norma, que ocorre no cotidiano como forma de disputa entre os trabalhadores de diversas células para saber quem produz melhor. Para Harvey, as "diferenças sociais" têm um papel fundamental na busca do controle capitalista por mobilizar o coletivo de trabalhadores ao redor de suas expectativas, dificultando-lhe a criação de laços de solidariedade e de ação coletiva. Ainda que ele esteja falando prioritariamente de diferenças de gênero, raça, etnia e orientação sexual, é possível ver, por exemplo, a estigmatização das lesionadas - com os comentários na fábrica de que seriam "encostadas" ou "inúteis" que não contribuíam para alcançar as metas (e, desse modo, obter o ganho máximo da PLR) - ou a exposição dos jornais do sindicato falando de seu caso em banheiros da fábrica como um exemplo de diferenças instrumentalizadas pelo controle capitalista.

\footnotetext{
"Quando pensamos na luta de classes, muitas vezes nossa imaginação gravita na figura do trabalhador que luta contra a exploração do capital. Mas, no processo de trabalho (como em outros lugares), a direção da luta é de fato oposta. É o capital que tem que lutar bravamente para tornar o trabalho servil no exato momento em que o trabalho é, potencialmente, todo-poderoso. Faz isso (...) pelas táticas de organização das relações sociais no chão da fábrica (...). Para produzir o capital, essas relações devem ser moldadas de forma colaborativa e cooperativa.

(...) A gama de táticas capitalistas no processo de trabalho precisa ser examinada. É aqui, em particular, que os capitalistas usam o poder das diferenças sociais em seu próprio benefício ao máximo" (HARVEY, 2011: 88-89).
}

Cida e Mônica mostram como a empresa tem conseguido ser bem sucedida nisto. Na voz de ambas, a satisfação e mesmo o "orgulho" de trabalhar na Natura estão relacionados a táticas de "organização das relações sociais no chão da fábrica" que obscurecem a exploração, a busca permanente pelo aumento da produtividade e mesmo a possibilidade de lesões - cuja presença é disseminada em várias das colegas - em decorrência da intensificação do trabalho para dar conta das metas empresariais e de suas expectativas de lucro. A extração da mais-valia e a consequente lucratividade, que permitem à Natura manter a liderança nacional do mercado de cosméticos e produtos de higiene pessoal, bem como a internacionalização crescente visível nos últimos anos assentam-se na capacidade que a gestão da empresa tem de mobilizar seu grande contingente de trabalhadores para dar conta do fluxo tensionado de produção que 
abastece a rede de mais de 1,5 milhão de consultoras, engajando-se na consecução das metas empresariais e nas formas flexíveis de organização da produção.

"O que é a Natura para mim? Bom, aqui é a empresa que eu gostei muito de trabalhar. Foi a primeira. (...) E o que eu sinto? Eu sinto prazer de trabalhar aqui, satisfeita. Têm pessoas que vem emburrada trabalhar. Eu não. Eu venho trabalhar bem até porque para eu desempenhar uma boa função eu preciso estar bem comigo mesma e isso ela passa para mim. Na hora do meu almoço, eu posso ir à academia, voltar no meu horário normal, sem ficar estressada, com fila de refeitório, com nada disso até porque aqui dificilmente aqui tem essa fila. O nosso gestor, o nosso coordenador, todo dia, coisas diferentes. (...) Eles conversam com a gente todos os dias, perguntam como a gente está" (Mônica).

"É uma empresa que eu falo: eu tenho orgulho de trabalhar aqui. As pessoas falam 'onde você trabalha?' e eu respondo: na Natura. As pessoas: 'nossa, na Natura!'. (...) Porque a gente tem orgulho de trabalhar aqui. Na Natura é assim. A maioria de nós, a imensa maioria de nós, tem orgulho de trabalhar aqui. É uma grande empresa. Mas aqui, como em todos os lugares, tem seus prós e seus contras. Mas é assim: eu estou satisfeita com a empresa. Ela oferece um monte de benefícios. Têm um monte de coisas. (...) Eu comecei a faculdade no começo do ano. Infelizmente, eu me candidatei lá para conseguir a bolsa, mas eu não fui contemplada. Eu espero que no meio do ano agora eu seja. Quer dizer, então, tem tudo isto. Tem a PLR, tem um convênio médico muito bom. (...) É uma empresa muito boa. Tem muita gente da fábrica mesmo, que tem a cabeça pequeninha e fala: 'ah, não sei o quê, essa empresa!'. Então vai trabalhar lá fora. Muita gente sai daqui e depois fala: 'poxa, o que eu perdi'. Então, é uma grande empresa. A gente tem orgulho de trabalhar aqui. Até no operacional. E procuro fazer o meu melhor. Porque, modéstia à parte, em muitas coisas eu me destaco. (...) A gente quer mostrar que a gente tem interesse, que a gente veste a camisa ${ }^{72 "}$ (Cida).

As atividades na célula semiautônoma, as metas e prêmios propostos pela Natura parecem relacionar-se justamente com os "jogos" descritos por Burawoy. Seus efeitos, como demonstrou o caso da demissão das trabalhadoras lesionadas, são a individualização das condutas, a ampliação da competitividade no interior do grupo operário e a erosão da solidariedade coletiva. As características da organização do trabalho e da produção na Natura dão os contornos dos aspectos ideológicos que a empresa busca fazer que sejam assumidos pelo grupo operário. A ausência de resistência às demissões das trabalhadoras lesionadas parece dar razão à forma como Michael Burawoy, em contraste com Braverman, entende o controle capitalista do trabalho e o modo como se organiza o consentimento à exploração.

\footnotetext{
${ }^{72}$ Cida não apenas falou de seu trabalho na empresa como também que, em suas horas livres, é consultora da Natura, o que talvez demonstre que seu orgulho tenha relação não apenas com aspectos de sua atividade na produção, mas também, possivelmente, de admiração pela marca Natura e apreço pelos produtos que ela utiliza e vende: "Eu trabalho aqui [e] eu sou consultora. Também sou consultora! Isso toma um tempo! É uma coisa que eu gosto de fazer, mas que tomou um rumo grande assim, mas me ocupa muito tempo. E eu tenho a minha casa, tenho dois filhos, né, que moram comigo. Então, eu tenho que chegar, arrumar a casa, fazer janta, fazer o pedido da Natura. Chegou o pedido da Natura, eu tenho que conferir, checar, separar, pôr na sacola para poder passar aqui na entrada [da fábrica, quando ela leva produtos para vender para as colegas] porque cada sacolinha você tem que lacrar. É meio difícil. Quer dizer, não é difícil. É trabalhoso, né? Então, assim, eu quase não tenho tempo de nada. Na minha casa o meu tempo já é curtinho e a faculdade também me toma um monte de coisa. Um monte de tempo".
} 
Pode-se dizer, adicionalmente, que o caso da Natura permite-nos corroborar o argumento desenvolvido por Burawoy - a partir de suas conclusões a respeito do "jogo" e do papel das instituições que organizam o consentimento na produção - que concorda com Bourdieu no que se refere à "ambiguidade do trabalho" e a sua "dupla verdade", mas dele se distancia ao sublinhar o papel da mistificação e das relações sociais na produção, para além do habitus, na separação vivenciada pelos trabalhadores entre a "verdade subjetiva" e a "verdade objetiva" da exploração do trabalho.

A discussão precedente, por sua vez, encontra interessante paralelo com as considerações de Beaud e Pialoux (2009), que, de um ponto de vista sociológico, mostraram como a transição de um padrão fordista para um padrão pós-fordista ${ }^{73}$ na produção industrial trouxe consigo a desmoralização da velha geração operária e de seus antigos valores, símbolos e totens, além de mudanças na composição demográfica do grupo operário e a valorização de uma "nova condição operária" afeita a tais transformações. Estas significaram, além de modificações técnicas, a busca pela adaptação da nova geração operária, mais escolarizada e que não foi socializada como a geração anterior, a uma nova forma de organizar a produção, muitas vezes mais intensa e lucrativa, mas que paradoxalmente propugnava o aumento da "autonomia" e da "polivalência" operárias. O caso da Peugeot-Sochaux, por eles estudado, trata-se de um notável caso empírico de distanciamento entre as "duas verdades do trabalho".

O que se tentou apresentar aqui, ao longo das páginas precedentes, é que a Natura, uma empresa global de capital nacional, também é um caso ilustrativo da busca pelo controle capitalista do obscurecimento da "verdade objetiva do trabalho", por meio de diversos "ganhos intrínsecos", bem como das mudanças paradigmáticas e transformações na classe operária pós-reestruturação produtiva. Quando, no capítulo 3, falou-se no paradoxo do "comprometimento" requerido pela empresa também se estava fazendo menção a isto. O "comprometimento", se por um lado é propagandeado pela empresa como adesão a valores (a "Essência" de que fala a Natura) de "transparência" nas relações e "autonomia dos colaboradores", por outro lado obscurece o requisito permanente de "comprometimento" com os fluxos produtivos e a garantia do aumento da produtividade e da realização das metas corporativas. Esta dissertação buscou contribuir com as discussões a respeito das mudanças na classe trabalhadora brasileira a

\footnotetext{
${ }^{73}$ Também descrita por Burawoy (1990) sob a forma das mudanças nos "regimes fabris".
} 
partir de um estudo de caso numa das empresas mais bem sucedidas no país na implantação de práticas flexíveis de produção e de internacionalização.

Curiosamente, nesta gigante multinacional dos cosméticos, pôde-se encontrar o discurso empresarial permanentemente maquiando o trabalho, seja em sua apresentação do sucesso empresarial - o qual se daria, por exemplo, pela atuação de seu exército de consultoras que teria "multiplicado os Luízes", pela inovação no uso de matérias-primas sustentáveis, por relações "transparentes" com as comunidades e pelo respeito ao meio ambiente - como também na forma de mobilização do trabalho dos milhares de operárias e operários de Cajamar, por meio da busca pela "aderência à Essência", pelo "comprometimento" com "valores" que obscurecem lesões e a intensificação do trabalho, ou pelo elogio do TPM e das células como forma de promover a "autonomia". 


\section{Referências bibliográficas}

ABILIO, Ludmila Costhek. O make-up do trabalho: uma empresa e um milhão de revendedoras de cosméticos. Tese de doutorado em Ciências Sociais. IFCH-Unicamp, Campinas, 2011.

- "Parece perfumaria: o trabalho de um milhão de revendedoras de cosméticos”. In: ESTANQUE, Elísio; MELLO E SILVA, Leonardo. Facetas do trabalho na contemporaneidade: diálogos luso-brasileiros. Curitiba: Editora Appris, 2012.

ALMEIDA, Maria Hermínia Tavares de. O Sindicato no Brasil: Novos Problemas: Velhas Estruturas. In: Debate e Crítica, São Paulo, vol. 6., Julho, 1975, pp. 49 - 74.

ANTUNES, Ricardo. "A era da informatização e a época da informalização: riqueza e miséria do trabalho no Brasil". In: ANTUNES, Ricardo (org.). Riqueza e miséria do trabalho no Brasil. São Paulo: Boitempo, 2006.

A rebeldia do trabalho. São Paulo: Editora Ensaio/Editora

Unicamp, 1988.

BEAUD, Stéphane; PIALOUX, Michel. Rebeliões urbanas e a desestruturação das classes populares (França 2005). In: Tempo Social, revista de sociologia da USP, v. 18, n. 1., junho de 2006. pp. $37-59$.

. Retorno à condição operária - investigação

em fábricas da Peugeot na França. São Paulo: Boitempo, 2009.

BENDAZZOLI, Milena. O consenso dos inocentes: construção do consentimento e privatização da vida. Dissertação de mestrado em Sociologia. FFLCH-USP, São Paulo, 2003.

BEYNON, Huw. Trabalhando para Ford - trabalhadores e sindicalistas na indústria automobilística. Rio de Janeiro: Paz e Terra, 1995.

BEYNON, Huw; NICHOLS, Theo. Patterns of work in the Post-Fordist Era: Fordism and Post-Fordism. Cheltenham: Edward Elgar Pub, 2006.

BOITO JR., Armando. "A crise do sindicalismo". In: SANTANA, Marco Aurélio; RAMALHO, José Ricardo (orgs.). Além da fábrica: trabalhadores, sindicatos e a nova questão social. São Paulo: Boitempo, 2003.

O sindicalismo de Estado no Brasil. São Paulo: Hucitec/Editora

da Unicamp, 1991. 
BOURDIEU, P. “A ilusão biográfica”. In: FERREIRA, Marieta de Moraes; AMADO, Janaína. Usos e abusos da história oral. Rio de Janeiro: Fundação Getúlio Vargas, 1998. 2. ed. pp. $183-191$.

Meditações Pascalianas. Rio de Janeiro: Bertrand Brasil, 2007. 2. ed.

O poder simbólico. Rio de Janeiro: Bertrand Brasil, 2011. 15. ed.

BRAVERMAN, H. Trabalho e capital monopolista. Rio de Janeiro: Zahar, 1983.

BURAWOY, Michael. A transformação dos regimes fabris no capitalismo avançado. In: Revista Brasileira de Ciências Sociais. n. 13. junho de 1990.

El consentimiento en la producción: Los cambios del proceso productivo em el capitalismo monopolista. Madri: Ministerio de trabajo y seguridad social, 1989.

O marxismo encontra Bourdieu. Campinas: Editora da

Unicamp, 2010.

The anthropology of industrial work. In: Annual Reviews Anthropology. n. 8. 1979. pp. $231-266$.

The politics of production. Londres: Verso, 1985.

CASTEL, Robert. As metamorfoses da questão social: uma crônica do salário. Petrópolis: Vozes, 2005. 5. ed.

CHESNAIS, François. A mundialização do capital. São Paulo: Xamã, 1996.

COMIN, Álvaro A.; CARDOSO, Adalberto M.; CAMPOS, André G. "As bases sociais do sindicalismo metalúrgico". In: ARBIX, Glauco A. T.; ZILBOVICIUS, Mauro. De JK a FHC, a reinvenção dos carros. São Paulo: Scritta, 1997. pp. 413 - 448.

COUTROT, Thomas. L'entreprise néo-libérale, nouvelle utopie capitaliste?. Paris: La Découverte, 1998.

Organização do trabalho e financeirização das empresas: a experiência europeia. In: Revista Outubro - Revista do Instituto de Estudos Socialistas, São Paulo, n. 12, 2005, pp. 33 - 43.

DEDECCA, Claudio Salvadori. "Flexibilidade e regulação de um mercado de trabalho precário - a experiência brasileira". In: GUIMARÃES, N. A.; HIRATA, H.; SUGITA, K.. Trabalho flexível, empregos precários?. São Paulo: Edusp, 2009. pp. 123 - 142. 
DINIZ, Eli; BOSCHI, Renato. "O corporativismo na construção do espaço público brasileiro". In: BOSCHI, Renato (org.). Corporativismo e desigualdade. Rio de Janeiro: Rio Fundo Editora, 1991.

DUBAR, Claude. A sociologia do trabalho frente à qualificação e a competência. In: Educação \& Sociedade. vol. 19. n. 64., setembro de 1999.

DURAND, Jean Pierre. A refundação do trabalho no fluxo tensionado. In: Tempo Social. n. 15. vol. 1. abril de 2003.

ELSON, Diane; PEARSON, Ruth. 'Nimble fingers make cheap workers': an analysis of women's employment in third world export manufacturing. In: Feminist Review Women in Third World Manufacturing, 1999.

FREYSSINET, Jacques. "As trajetórias nacionais rumo à flexibilidade da relação salarial - a experiência europeia". In: GUIMARÃES, N. A.; HIRATA, H.; SUGITA, K.. Trabalho flexível, empregos precários?. São Paulo: Edusp, 2009. pp. 25 - 48.

GALVÃO, Andréia. Neoliberalismo e reforma trabalhista no Brasil. Tese de doutorado em Ciências Sociais. Unicamp, Campinas, 2003.

GEREFFI, Gary; KORZENIEWICZ, Miguel. Commodity chains and global capitalism. Westport: Praeger, 1994.

HARVEY, David. Condição pós-moderna: uma pesquisa sobre as origens da mudança cultural. São Paulo: Loyola, 2011. 21. ed.

O enigma do capital: e as crises do capitalismo. São Paulo: Boitempo, 2011.

HIRATA, Helena. A precarização e a divisão internacional e sexual do trabalho. In: "Sociologias", Porto Alegre, ano 11. n. 21. jan/jul 2009. pp. 24 - 41.

. "Da polarização das qualificações ao modelo da competência: a evolução do debate no contexto dos novos paradigmas produtivos”. In: FERRETTI, C.J. et al (org.). Novas tecnologias, trabalho e educação: um debate multidisciplinar. Petrópolis: Vozes, 1994. Pp. $124-138$.

. "Flexibilidade, trabalho e gênero". In: Hirata, Helena.; SEGNINI, Liliana. Organização, trabalho e gênero. São Paulo: Editora Senac, 2007. pp. 91 - 108. 
- "Globalização e divisão sexual do trabalho numa perspectiva comparada”. In: GUIMARÃES, N. A.; HIRATA, H.; SUGITA, K.. Trabalho flexível, empregos precários?. São Paulo: Edusp, 2009. pp. 145 - 167.

. Nova divisão sexual do trabalho? Um olhar voltado para a empresa e a sociedade. São Paulo: Boitempo, 2002.

- Sobre o modelo japonês: automatização, novas formas de organização e de relações de trabalho. São Paulo: Edusp, 1993.

HOLANDA, Sergio Buarque de. Raízes do Brasil. São Paulo: Companhia das Letras, 1995. 26. ed.

HUMPHREY, John. Fazendo o "milagre": controle capitalista e luta operária na indústria automobilística brasileira. Petrópolis: Vozes/CEBRAP, 1982.

INGLEHART, Ronald. Democratização em perspectiva global. In: Opinião Pública, Campinas, vol. 1, n. 1, Julho/Agosto, 1993, pp. $9-67$.

KREIN, José Dari. Tendências recentes nas relações de emprego no Brasil: 1990 2005. Tese de doutorado em Economia. Unicamp, Campinas, 2007.

LIMA, Jacob Carlos. Participação, empreendedorismo e autogestão: uma nova cultura do trabalho? In: Sociologias, Porto Alegre, ano 12, n. 25, set/dez. 2010, pp. 158 - 198.

LOPES, Juarez Rubens Brandão. Sociedade Industrial no Brasil. São Paulo: Difusão Européia do Livro, 1971. 2. ed. [1. ed. 1964].

MELLO E SILVA, Leonardo. "Trabalho e regresso: entre desregulação e re-regulação". In: OLIVEIRA, Francisco; BRAGA, Ruy; RIZEK, Cibele (orgs.). Hegemonia às avessas: economia, política e cultura na era da servidão financeira. São Paulo: Boitempo, 2010.

MOLINIER, Pascale. A dimensão do cuidar no trabalho hospitalar: abordagem psicodinâmica do trabalho de enfermagem e dos serviços de manutenção. In: Revista Brasileira de Saúde Ocupacional, São Paulo, 33 (118), 2008.

PIALOUX, M. “O velho operário e a nova fábrica”. In: BOURDIEU, P. (org.). A miséria do mundo. Petrópolis: Vozes, 2011. 8. ed.

PIORE, Michael; SABEL, Charles. The Second Industrial Divide: Possibilities for Prosperity. New York: Basic Books, 1984. 
RELATÓRIO

NATURA

2010.

Disponível

em

http://scf.natura.net/Conteudo/Default.aspx?MenuStructure=5\&MenuItem=12

(consultado em 07/07/2011).

RELATÓRIO NATURA 2011. Disponível em http://

http://scf.natura.net/relatorios/2011/abertura_ra_site/arquivos/ra_2011_navegavel_port.

pdf (consultado em 25/07/2012).

RELATÓRIO NATURA 2012. Disponível em http://

http://relatorio.natura.com.br/relatorio/.

RODRIGUES, Leôncio Martins. Destino do sindicalismo. São Paulo: Edusp, 1999.

RODRIGUES, Leôncio Martins. "O Sindicalismo corporativo no Brasil”. In: RODRIGUES, Leôncio Martins. Partidos e Sindicatos - Escritos de Sociologia Política, São Paulo: Ática, 1990.

SENETT, Richard. A corrosão do caráter. São Paulo, Record, 1999.

SILVA, Elizabeth Bortolaia. Refazendo a fábrica fordista - contrastes da indústria automobilística no Brasil e na Grã-Bretanha. São Paulo: Hucitec, 1991.

SOARES, Angelo. “As emoções do care”. In: HIRATA, Helena; GUIMARÃES (orgs.), Nadya. Cuidado e cuidadoras. São Paulo: Editora Atlas, 2012.

TELLES, Vera et al. Entrevista com Michel Pialoux e Stéphane Beaud. In: Tempo Social, revista de sociologia da USP, v. 18. n. 1. junho de 2006. pp. 13 - 36.

TOMIZAKI, Kimi A. Ser metalúrgico no ABC: transmissão e herança da cultura operária entre duas gerações de trabalhadores. Campinas: Arte Escrita, 2007.

WOMACK, James; ROOS, Daniel; JONES, Daniel. A máquina que mudou o mundo: baseado no estudo do Massachusetts Institute of Tecnology sobre o futuro do automóvel. Rio de Janeiro: Elsevier, 2004. 8. ed. 